\title{
Glucosinolate-Containing Seed Meal as a Soil Amendment to Control Plant Pests
}

Subcontract Report NREL/SR-510-35254 July 2005

2000-2002

J. Brown, M.J. Morra

University of Idaho

Moscow, Idaho

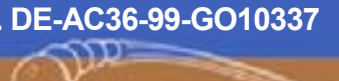




\section{Glucosinolate-Containing Seed Meal as a Soil Amendment to Control Plant Pests}

2000-2002

J. Brown, M.J. Morra

University of Idaho

Moscow, Idaho

NREL Technical Monitor: K. Shaine Tyson

Prepared under Subcontract No. XC0-929095-01

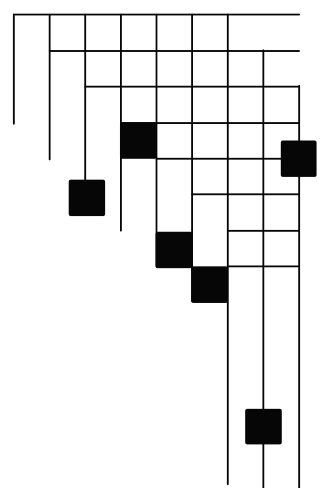




\section{NOTICE}

This report was prepared as an account of work sponsored by an agency of the United States government. Neither the United States government nor any agency thereof, nor any of their employees, makes any warranty, express or implied, or assumes any legal liability or responsibility for the accuracy, completeness, or usefulness of any information, apparatus, product, or process disclosed, or represents that its use would not infringe privately owned rights. Reference herein to any specific commercial product, process, or service by trade name, trademark, manufacturer, or otherwise does not necessarily constitute or imply its endorsement, recommendation, or favoring by the United States government or any agency thereof. The views and opinions of authors expressed herein do not necessarily state or reflect those of the United States government or any agency thereof.

Available electronically at http://www.osti.gov/bridge

Available for a processing fee to U.S. Department of Energy and its contractors, in paper, from:

U.S. Department of Energy

Office of Scientific and Technical Information

P.O. Box 62

Oak Ridge, TN 37831-0062

phone: 865.576 .8401

fax: 865.576 .5728

email: mailto:reports@adonis.osti.gov

Available for sale to the public, in paper, from:

U.S. Department of Commerce

National Technical Information Service

5285 Port Royal Road

Springfield, VA 22161

phone: 800.553 .6847

fax: 703.605.6900

email: orders@ntis.fedworld.gov

online ordering: http://www.ntis.gov/ordering.htm

This publication received minimal editorial review at NREL 


\section{Contents}

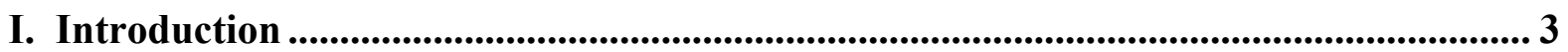

II. Glucosinolates ........................................................................................................................ 4

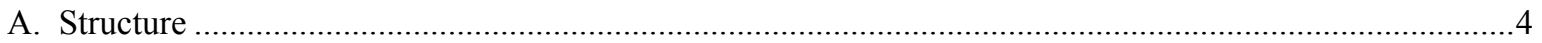

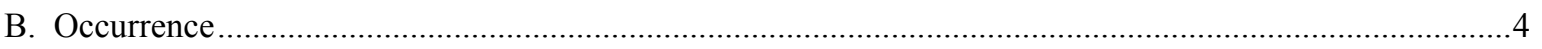

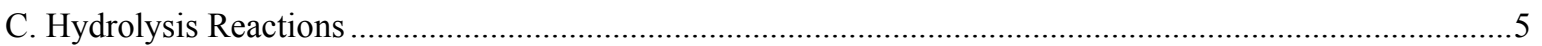

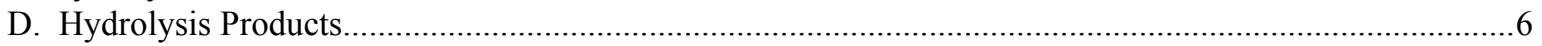

III. Pesticidal Activity of Glucosinolate Hyrolysis Products ..................................................... 8

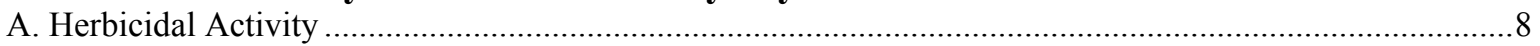

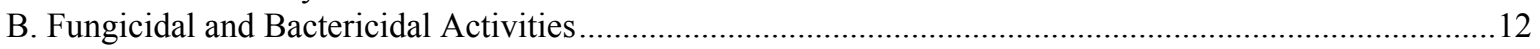

C. Allelochemical Effects on Insects and Other Invertebrates ....................................................... 17

IV. Management Considerations ............................................................................... 19

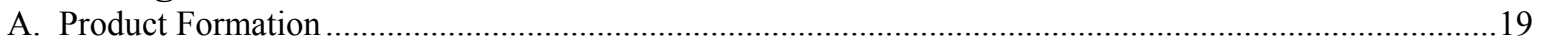

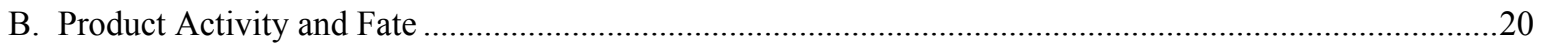

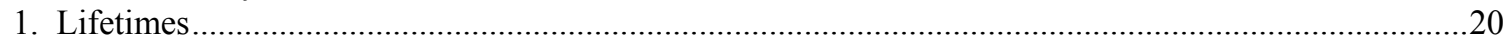

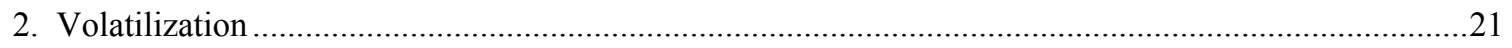

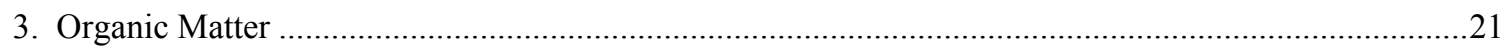

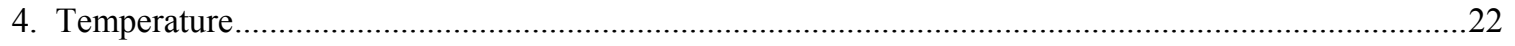

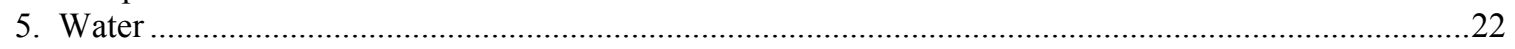

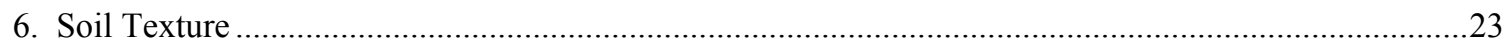

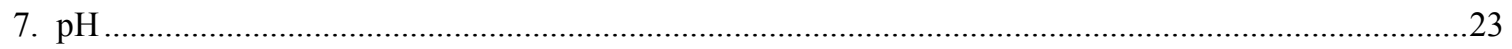

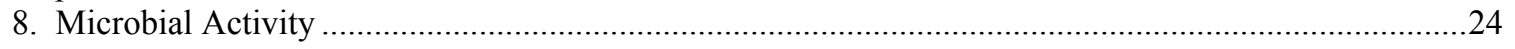

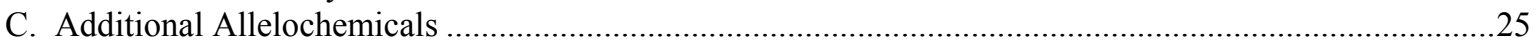

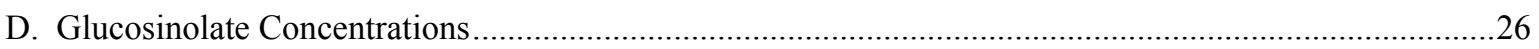

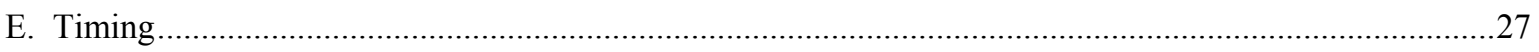

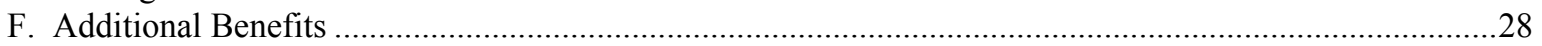

V. Crushing and Extraction Technology .................................................................................... 29

VI. Allergenic Reactions ............................................................................................................. 30

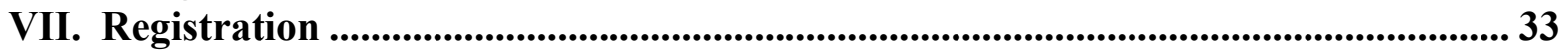

VII. Genetics and Interspecific Hybridization ........................................................................ 34

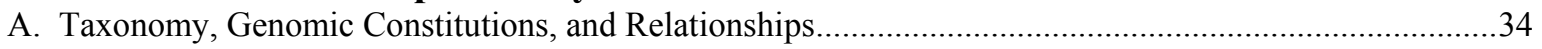

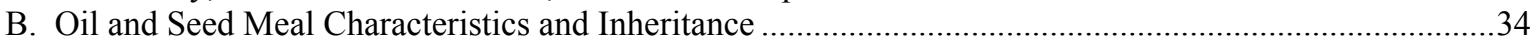

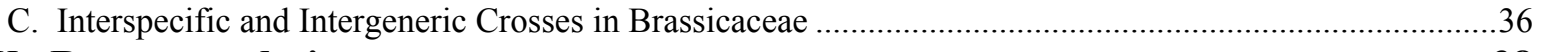

IX. Recommendations .......................................................................................................... 38

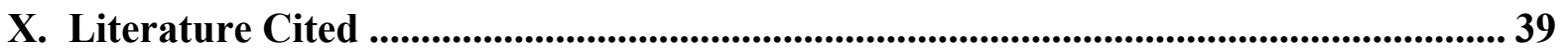




\section{Tables}

Table 1. Naturally Occurring Glucosinolates

Table 2. Effects of Aqueous Extracts from Glucosinolate-Containing Tissues on Other Plants ..........83

Table 3. Influence of Naturally Occurring Isothiocyanates on Microorganisms ....................................85

Table 4. EPA Registrations for Various Isothiocyanates .....................................................................92

\section{Figures}

Figure 1. Generalized structure of glucosinolates .

Figure 2. Glucosinolate degradation pathway. Enzymatic hydrolysis results in production of glucose followed by $\mathrm{HSO}_{4}^{-}$. At least seven other products have been observed. Oxazolidinethione and $\mathrm{SCN}^{-}$are thought to be formed from unstable $\mathrm{R}-\mathrm{N}=\mathrm{C}=\mathrm{S}$ intermediates.......................................94

Figure 3. Relationship between Brassica species as described by $\mathrm{U}(1935)$........................................95 


\section{Glucosinolate-Containing Seed Meal as a Soil Amendment to Control Plant Pests}

\section{Introduction}

Plants may produce compounds that directly or indirectly affect their biological environment. These compounds fall within a broad category of compounds called allelochemicals, and are exclusive of food that influences growth, health, or behavior of other organisms (Whittaker and Feeney 1971). One reason for interest in allelochemicals is their potential for use in alternative pest management systems. Using plant-produced allelochemicals in agricultural and horticultural practices could minimize synthetic pesticide use, reduce the associated potential for environmental contamination, and contribute to a more sustainable agricultural system.

Glucosinolates, compounds that occur in agronomically important crops, may represent a viable source of allelochemic control for various soil-borne plant pests. Extensive studies of several hundred species of the Brassicaceae (Cruciferae) family indicate that virtually all may be capable of producing glucosinolates (Kjaer 1976). Insecticidal, nematicidal, fungicidal, and phytotoxic effects are often associated with tissues of cruciferous plants. As such, glucosinolates are commonly considered to be ultimately responsible for pest suppression.

In this review we consider what is known about glucosinolates and the factors involved in potential application of glucosinolate-containing tissues in pest control strategies. We will focus on the use of seed meal, but supporting work involving the use of other parts of the plant will be presented when necessary. However, glucosinolates are not biologically active, but are the precursors for the formation of a variety of potential allelochemicals. Much of the past emphasis and available literature have focused on isothiocyanates (ITCs), apparently the most important of those allelochemicals. Any delivery system designed to take advantage of this chemistry must consider the fact that glucosinolates must be enzymatically hydrolyzed and that multiple pesticidal compounds may be produced. As such, we will first provide an overview of glucosinolate chemistry and the relevant hydrolytic reactions. The most recent and comprehensive reviews concerning glucosinolates are those of Brown and Morra (1997), Fahey et al. (2001), and Rosa et al. (1997). 


\section{Glucosinolates}

\section{A. Structure}

Ettlinger and Lundeen in 1956 (Fig. 1) described the general structure for glucosinolates. Found in dicotyledonous plants, they are a class of organic anions usually isolated as potassium or sodium salts (Larsen 1981), but occasionally in other forms. For example, $p$ hydroxybenzyl glucosinolate is isolated as a salt complex with sinapine; an organic cation derived from choline (Challenger 1959; Kjaer 1960; Van Etten and Tookey 1979). Features

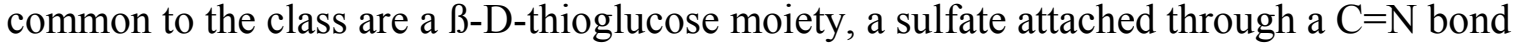
(sulfonated oxime), and a side group (designated R) that distinguishes one glucosinolate from another. More than 100 different $\mathrm{R}$ groups, and thus glucosinolates, have been identified or inferred from degradative products (Table 1).

\section{B. Occurrence}

Glucosinolates are especially abundant among families of the order Capparales: Tovariaceae, Resedaceae, Capparaceae, Moringaceae, and Brassicaceae. Families outside the order exhibit occasional occurrence and include the Caricaceae, Euphorbiaceae, Gyrotemonaceae, Limnathaceae, Salvadoraceae, and Tropaeolaceae families (Fenwick et al. 1983). A recent literature review provides a comprehensive list of all species known to contain glucosinolates (Fahey et al. 2001).

Glucosinolate types in plant species are highly variable. For example, the main glucosinolate in radish seed (Raphanus sativus) is 4-methylsulphinyl-3-butenyl glucosinolate, while mustard seed (Brassica juncea) is dominated by propenyl glucosinolate. Cabbage seed (Brassica oleracea) contains mainly propenyl and 2-hydroxy-3-butenyl glucosinolate; rapeseed (Brassica napus) contains 4 major glucosinolates: 2-hydroxy-3-butenyl, 3-butenyl, 4-pentenyl, and 2-hydroxy-4-pentenyl (Sang et al. 1984). Similar differences in glucosinolate types are observed when comparing vegetative plant parts (Hill et al. 1987; Josefsson 1967b).

Numerous authors have shown that glucosinolate concentrations vary within plants of a single species, and that fluctuations occur with plant age (Carlson et al. 1987; Chong and Bible 1974; Clossais-Besnard and Larher 1991; Elliott and Stowe 1971; Freer et al. 1989; Griffiths et al. 1991; Johnston and Jones 1966; Josefsson 1967a; Josefsson and Appelqvist 1968; Kondo et al. 1985; Macfarlane-Smith and Griffiths 1988; Paxman and Hill 1974). Additional environmental factors such as spacing, moisture regime, and nutrient availability affect concentration (Freeman and Mossadeghi 1973; Josefsson 1970a, 1970b; Ju et al. 1982; Louda et al. 1987; MacLeod and Nussbaum 1977; Mailer and Pratley 1990). Glucosinolate type and quantity also vary within tissues of an individual plant. The major glucosinolate in radish seed is not detected in radish leaves or roots; propenyl glucosinolate is found in all $B$. juncea tissues (Sang et al. 1984). 


\section{Hydrolysis Reactions}

Toxicity is not attributed to intact glucosinolates, but instead to biologically active products such as ITCs, organic cyanides, oxazolidinethiones (OZTs), and ionic thiocyanate ( $\left.\mathrm{SCN}^{-}\right)$ released upon enzymatic degradation by myrosinase (thioglucoside glucohydrolase, EC 3.2.3.1) in the presence of water. Degradation also occurs thermally or by acid hydrolysis (Kjaer 1976; MacLeod et al. 1981).

Myrosinase is not properly identified as a single enzyme, but rather as a family or group of similar-acting enzymes. Multiple forms of the enzymes exist, both among species and within a single plant (Bones and Slupphaug 1989; Falk et al. 1992, 1995a; Lenman et al. 1990, 1993a; Xue et al. 1993), and all perform a similar function (Björkman 1976). Although their genetic sequences are similar to other B-glycosidases (Lenman et al. 1993b), myrosinases are fairly specific toward glucosinolates (Durham and Poulton 1990). These enzymes cleave the sulfur-glucose bond regardless of either the enzyme or substrate source. However, the particular enzyme and glucosinolate substrate influence reaction kinetics (Bones 1990; MacLeod and Rossiter 1986). In addition to plants, the enzymes have been discovered in the bacterium Enterobacter cloacae and the fungus Aspergillus sydowi (MacLeod and Rossiter 1986). Myrosinase-like activity has also been observed in soils (Borek et al. 1996a; Chae and Tabatabai 1983).

Myrosinase and glucosinolates are separated from each other in intact plant tissues; however, the precise nature of the arrangement has not been easy to determine. Evidence suggesting myrosinase is a cytosolic enzyme associated with membranes, perhaps surrounding a vacuole containing glucosinolates (Lüthy and Matile 1984; Thangstad et al. 1990), has been supplanted by that obtained using more precise methodologies. Glucosinolates are probably contained in vacuoles of various types of cells (Grob and Matile 1979; Pocock et al. 1987). In contrast, myrosinase is contained only within structures, called myrosin grains, of specialized myrosin cells that are distributed among other cells of the plant tissue (Höglund et al. 1992; Thangstad et al. 1991). As glucosinolate vacuoles do not appear to be present within myrosin cells, intercellular rather than intracellular separation occurs. Disrupting cellular tissues allows glucosinolates and myrosinase to mix, resulting in the rapid release of glucosinolate degradation products. Myrosinase activity and glucosinolates are preserved in cold-pressed meal and are no longer physically separated. Thus, adding water immediately results in the production of the hydrolysis products, including isothiocyanate, without the need for additional tissue maceration.

Enzymatic degradation is influenced by a number of variables, and reviews are available (Chew 1988a; Fenwick et al. 1983; McDanell et al. 1988; McGregor et al. 1983; Sørensen 1990; Tookey et al. 1980; Van Etten and Tookey 1979; Van Etten and Wolff 1973; Van Etten et al. 1969). In the presence of moisture, glucosinolate hydrolysis produces glucose, sulfate, and an additional aglucon product(s) from the remaining N, C, S, and R groups (Figure 2). The latter product is proposed to go through at least one unstable intermediate, the ultimate form controlled by reaction conditions including $\mathrm{pH}$, R-group, and the presence of metal ions such as $\mathrm{Fe}^{+2}$. In addition, smaller proteins or coenzymes accompany 
myrosinase and may alter the product profile (Falk et al. 1995b; Taipalensuu et al. 1996). Several possible products that exhibit some form of biological activity may be formed (Fig. 2). The products are all interrelated in that they are isomers or result from further fission of the isomers.

\section{Hydrolysis Products}

ITCs have historically been considered the "normal" products of glucosinolate breakdown. They are often volatile with pungent flavors or odors. The presence of propenyl ITC in mustards and horseradish is responsible for much of the flavor; thus, ITCs are sometimes called mustard oils. Formation requires that the initial unstable aglucon intermediate undergo a Loessen rearrangement to the $\mathrm{R}-\mathrm{N}=\mathrm{C}=\mathrm{S}$ configuration. Isothiocyanates are quite reactive, although less so than the related isocyanates $(\mathrm{R}-\mathrm{N}=\mathrm{C}=\mathrm{O})$. A few commercially available soil fumigants depend on the activity of methyl ITC either as the parent compound or as produced from precursors such as sodium N-methyldithiocarbamate or tetrahydro-3,5dimethyl-2H-1,3,5-thiadiazine-2-thione. Because of known toxicities, ITCs are often considered likely candidates for pesticidal activity.

The ability of ITCs to form cyclic thione compounds (Hughes 1975) is believed to occur in a spontaneous intramolecular reaction when the ITC contains a $\beta$ hydroxyl group on the side chain (R-group) (Fig. 2). The goitrogenic OZTs so formed are major products from rapeseed (B. napus).

Nitrile character is common to four additional products. Forming a nitrile $(\mathrm{R}-\mathrm{C} \equiv \mathrm{N}$, also known as an organic cyanide), which does not require rearrangement, involves sulfur loss from the molecule. Nitrile formation is favored over ITC at low $\mathrm{pH}$, but occurs in some crucifers at a $\mathrm{pH}$ where ITC is normally the dominant product (Gil and MacLeod 1980). The presence of $\mathrm{Fe}^{+2}$ or thiol compounds increases the likelihood of nitrile formation (Hasapis and MacLeod 1982; Uda et al. 1986a, 1986b). Epithionitrile formation requires the same conditions as for nitriles, plus terminal unsaturation of the R-group and the presence of an epithiospecifier protein. The epithiospecifier protein possesses a rare property in that it is an enzyme cofactor that allosterically directs an enzyme to yield a different product (MacLeod and Rossiter 1985; Petroski and Kwolek 1985; Petroski and Tookey 1982). Thiocyanate (R$\mathrm{S}-\mathrm{C} \equiv \mathrm{N}$ ) is sometimes produced, particularly in members of the Alyssum, Coronopus, Lepidium, and Thlaspi families (Fenwick et al. 1983). Factors controlling organic thiocyanate formation are not well understood (Larsen 1981).

$\mathrm{SCN}^{-}$production from glucosinolates is controlled by the presence of specific R-groups. Evidence suggests the anion is a resonance hybrid with greater charge on the $\mathrm{S}$ (Hughes 1975; Witczak 1986); however, charge can be localized on either the sulfur (-S-C $\equiv \mathrm{N})$ or the nitrogen $\left(\mathrm{S}=\mathrm{C}=\mathrm{N}^{-}\right)$, depending on the environment (Beekhuis 1975). Indole and 4hydroxybenzyl glucosinolates yield $\mathrm{SCN}^{-}$thought to arise from a highly unstable ITC intermediate. $\mathrm{SCN}^{-}$is formed from indole glucosinolates over a wide $\mathrm{pH}$ range, whereas 4hydroxybenzyl glucosinolates is typically thought to yield $\mathrm{SCN}^{-}$only at a more basic $\mathrm{pH}$. We have recently determined that 4-OH benzyl isothiocyanate was not stable even at $\mathrm{pH}$ 
values of 3.0 (Borek and Morra, 2003). The half-life decreases with an increase in $\mathrm{pH}$ from $3.6 \mathrm{~h}$ at $\mathrm{pH} 3.0$ to less than $5 \mathrm{~min}$ at $\mathrm{pH} 7.0$.

Indolylic compounds also result during $\mathrm{SCN}^{-}$production from indole glucosinolate hydrolysis. 3-Indolylmethanol, the immediate product, may form ascorbigen or 3,3'diindolylmethane (McDanell et al. 1988). 3-Indolylacetonitrile, indole acetic acid, and dioxindoles may be formed under conditions favoring nitrile formation (McDanell et al. 1988; Monde et al. 1991). Indolylic compounds in these plant tissues are also formed by routes other than glucosinolate degradation (Monde et al. 1991; Takasugi et al. 1988). 


\section{Pesticidal Activity of Glucosinolate Hyrolysis Products}

\section{A. Herbicidal Activity}

Glucosinolate-containing plants have a reputation for affecting successive or nearby plant communities. Various negative or inhibitory effects can occur. At one time dyer's woad (Isatis tinctoria) cultivation was restricted because of a negative influence on following crops (Elliott and Stowe 1971; Fenwick et al. 1983). Yields of legumes (such as clover) and, to a lesser extent, grass are reduced following a Brassica crop (Campbell 1959; Kutácek 1964). Campbell (1959) showed that pieces of B. oleracea roots placed in a petri dish with seeds of clover (Trifolium repens) inhibited germination, suggesting direct involvement of compounds from the Brassica plants. Flax yields decrease if species of Camelina are present as weeds (Grümmer and Beyer 1960). Brassica herbage reduced stand establishment of five crop species more than twice as much as barley (Hordeum vulgare) amendments (Vera et al. 1987). Similarly, canola stubble was more inhibitory to wild oat (Avena sterilis) emergence than wheat or pea (Jones 1992). Stands of wild Brassica nigra appeared to inhibit germination of annual grasses (Bell and Muller 1973), and broccoli (B. oleracea) residues amended to soil reduced germination and growth of lettuce for 10-21 d (Patrick et al. 1963). Researchers in Sweden demonstrated that Sinapis alba seed meal applid to the soil suppresses weed emergence (Ascard and Jonasson 1991; Johansson 1992; Johansson and Ascard 1994; Oleszek et al. 1994). For example, mustard meal or "cake," applied in rows between cole crops with the intent of attracting enemies of the cabbage root fly also reduced numbers of several annual weeds (Ascard and Jonasson 1991).

Results with respect to plant inhibition are not always clear, however, and sometimes appear inconsistent or contradictory. For example, heavy rape residues (Brassica campestris L.) reduced wheat, barley, and oat growth in a field trial, but soil $\mathrm{N}$ concentrations measured under heavy residues were less than under light residues. Differences in soil nutrient status were thus possibly responsible for the effect (Horricks 1969). Similar studies using rape straw and chaff residue at $8,970 \mathrm{~kg} \mathrm{ha}^{-1}$ showed reduced emergence of bromegrass and alfalfa, and reduced growth of barley, bromegrass, and alfalfa, but reductions were not significantly different than in controls using wheat straw (Waddington 1978; Waddington and Bowren 1978). The effect was ameliorated by applying inorganic nitrogen fertilizer; however, subsequent studies indicate that nitrogen limitations do not fully explain the inhibition (Mason-Sedun and Jessop 1988; Mason-Sedun et al. 1986).

Many variables contribute to differences in phytotoxicity. The Brassica species or cultivar may control the level of phytotoxicity (Mason-Sedun et al. 1986), although differences are not always dramatic (Vera et al. 1987) and may be influenced by the plant growth stage. Fresher plant tissues are more effective inhibitors than straw or stubble that has been stored or left after harvest. Aqueous extracts of fresh wild mustard (B. campestris) tissues produce a stronger inhibition of growth than those from aged tissues (Jiménez-Orsornio and Gliessman 1987). Green Brassica herbage reduced stand establishment more than Brassica straw and chaff, which caused only sporadic reductions (Vera et al. 1987). Rape stubble 
residues were less or no more effective than pea or wheat residues in inhibiting wheat germination and growth (Jessop and Stewart 1983). The greatest inhibition of wheat occurred with freshly dried Brassica residues, an effect that declined with older residues (Mason-Sedun et al. 1986). Microbial degradation of the tissues may produce compounds apart from glucosinolates that are associated with plant inhibition or stimulation, further complicating data interpretation (Harper and Lynch 1982; Lovett and Duffield 1981; Lovett and Jackson 1980). The target plant species also vary in tolerance to the allelochemicals (Kasting et al. 1974; Oleszek 1987). Tomatoes planted in cabbage-amended soil seem particularly sensitive, wilting within $24 \mathrm{~h}$ (Ramirez-Villapudua and Munnecke 1988). Suppression of germination may in part be related to seed size, with smaller seeds being more susceptible (Vera et al. 1987).

Many studies concerning the effects of glucosinolate-containing plant tissues on plant growth have focused on water-soluble compounds as the responsible agents. Aqueous extracts of various Brassica and Camelina reduce seedling growth or inhibit germination (Table 2). Negative effects are not consistent in all species, and some plants show no change or are actually stimulated. There are not always correlations between germination inhibition and growth inhibition. Aqueous extracts had little effect on tomato germination, but severely inhibited growth just after germination (Gressel and Holm 1964). Depending on plant part, growth stage, or other conditions, extracts from the same plant species may be inhibitory or stimulatory to the target species (Jiménez-Orsornio and Gliessman 1987).

Intact glucosinolates are water soluble, but of several that have been tested for biological effects, only 3-indolylmethyl glucosinolate has produced inhibition of plant growth (Bialy et al. 1990; Kutacek 1964). High concentrations of 3-indolylmethyl glucosinolate in woad may be responsible for its inhibition of other plants, possibly by converting some of this glucosinolate to auxins (Andersen and Muir 1966; Elliott and Stowe 1971; Kutacek 1964; Stewart 1939). Ascorbigen, another possible water-soluble degradation product of this glucosinolate, inhibited germination and growth of clover, but only at relatively high concentrations $\left(10^{-2}-10^{-3} \mathrm{M}\right)$ (Kutacek 1964).

The water-soluble glucosinolate degradation product most studied in relation to plant growth and herbicidal potential is $\mathrm{SCN}^{-}$. The herbicidal formulation amitrole-T consists of a mixture of amino-1,2,4-triazole and $\mathrm{NH}_{4} \mathrm{SCN}$. Thiocyanate salts such as $\mathrm{KSCN}$ and $\mathrm{NH}_{4} \mathrm{SCN}$ can be used as selective herbicides and defoliants by varying the concentrations. Oxalis and spurge in lawns are killed at $\mathrm{SCN}^{-}$concentrations between 1.7-14 $\mathrm{g} \mathrm{L}^{-1}(0.17-1.4 \%)$, and about 11.2 $\mathrm{kg} \mathrm{ha}^{-1}$ is used to defoliate cotton (Beekhuis 1975). At $112 \mathrm{~kg} \mathrm{ha}^{-1}$ control of poison ivy, poison sumac, and poison oak is at least as favorable as control by 2,4-D or sodium arsenite. At $897 \mathrm{~kg} \mathrm{ha}^{-1} \mathrm{SCN}^{-}$is a temporary soil sterilant (Beekhuis 1975). $\mathrm{SCN}^{-}$is produced by $B$. napus and $S$. alba meals and thus it is of possible importance in pest control. $\mathrm{SCN}^{-}$is not expected to be a signficant product from $B$. juncea meal.

At rates closer to what might be encountered in natural situations $\left(500 \mu \mathrm{M} \mathrm{SCN}^{-}\right)$, percent germination of 39 different species and cultivars did not differ from controls, but growth of 22 species was adversely affected (Stiehl and Bible 1989). Early growth inhibition of some plants was also observed in bioassays by Park et al. (1983), while in hydroponic cultures Ju 
et al. (1983) found complete kill of tobacco at $<5 \mu \mathrm{g} \mathrm{mL}{ }^{-1}$ and of beans at concentrations over $25 \mu \mathrm{g} \mathrm{mL}^{-1}$. Cabbage growth was severely inhibited, though not completely killed, at $100 \mu \mathrm{g} \mathrm{mL}^{-1}$. SCN ${ }^{-}$accumulated in plant tissues and toxicity positively correlated with tissue $\mathrm{SCN}^{-}$concentrations (Stiehl and Bible 1989; Ju et al. 1983). Squash seedlings had low $\mathrm{SCN}^{-}$ concentrations in their tissues, suggesting that some plants may degrade or do not readily take up the anion (Stiehl and Bible 1989). Wu and Bassler (1969) found that $\mathrm{SCN}^{-}$ inactivates cotton chloroplasts by inhibiting $\mathrm{O}_{2}$ release. Ionic thiocyanate-induced chlorosis may be related to $\mathrm{SCN}^{-}$interactions with iron (Ju et al. 1983). Additional interesting effects of $\mathrm{SCN}^{-}$on plants include increased yield $(6 \%-15 \%)$ when seed potatoes are coated with $0.02 \% \mathrm{SCN}^{-}$and induced apple reddening by $\mathrm{SCN}^{-}$sprays (Beekhuis 1975; Dustman and Duncan 1940).

Other water-soluble glucosinolate degradation products likely play important roles in altering seed germination and plant growth. Water soluble compounds from B. napus defatted seed meal severely inhibited lettuce seed germination and those from $B$. napus leaf tissue completely inhibited germination (Brown and Morra 1995, 1996). In contrast, aqueous extracts of root tissue had only a minor influence on germination. Several organic water soluble glucosinolate degradation products from the tissues were found by back-extracting aqueous extracts of the seed meal with $\mathrm{CH}_{2} \mathrm{Cl}_{2}$ and a $\mathrm{CaCl}_{2}$ solution. Water-soluble products were particularly high in the seed meal and included 5-vinyl OZT, 5-propenyl OZT, 1-cyano3-butene, 3,4-epithiobutyl CN, 2-hydroxy-3,4-epithiobutyl CN, 4-methylsulfinylbutyl ITC, and 5-methylsulfinylpentyl ITC. In addition, $\mathrm{SCN}^{-}$is found in water extracts of seed meal and is an expected product in other tissues in lesser amounts (Brown and Morra 1991; Brown et al. 1991). These water-soluble glucosinolate products are probably involved in the inhibition of germination by seed meal tissue. However, inhibition of lettuce seed germination by water-soluble compounds from leaf and stem tissues could not be explained entirely by the total amount of identified glucosinolate degradation products (Brown and Morra 1996). This suggests either high toxicity for specific nonvolatile ITCs found in leaf and stem tissues or the participation of unidentified compounds.

Plant tissue extract phytotoxicity correlates with tissue amendment phytotoxicity, but residues are generally more effective inhibitors of seed germination than aqueous extracts (Mason-Sedun and Jessop 1988; Mason-Sedun et al. 1986). The greater inhibitory effect of residues suggests that something other than water-soluble toxins influences germination. Volatile ITCs are probably the major allelochemicals responsible for inhibitory effects on plants, although some have disputed the practical significance of these compounds in vivo (Bell and Muller 1973; Choesin and Boerner 1991).

Plant toxicity is illustrated by methyl ITC, often studied because of its use as a commercial soil fumigant. Methyl ITC is usually generated in situ from a precursor (e.g. dithiocarbamate), but may be applied directly (Miller 1988). The fumigant Vapam, which releases methyl ITC, was the only one of four soil fumigants found to be toxic to strawberry plants when applied as a drench (Eide 1959). Residues of methyl ITC must be degraded before planting commences because of phytotoxicity (Sirons 1973). Methyl ITC inhibits growth and germination of weeds such as pigweed, dandelion, lambsquarter, bermuda grass, 
purslane, crabgrass, quackgrass, spurge, fleabane, barnyard grass, fall panicum, common ragweed, stinkgrass, henbit, and carpetweed (Beekhuis 1975; Teasdale and Taylorson 1986).

Many weed seeds are killed while dormant, a capability distinguishing ITCs from other herbicides. Activity in the gas phase for propenyl ITC as well as methyl ITC was demonstrated by complete or severe germination inhibition of corn, soybeans, wheat, rapeseed, cucumber, carrot, alfalfa, dandelion, redroot pigweed, and barnyard grass at concentrations of $1 \mathrm{ppm}$ in the headspace of airtight containers (Vaughn and Boydston 1995). Although exact mechanisms of germination inhibition by ITCs are not known, evidence suggests interference with protein synthesis and possibly processes involved in the formation of phosphorylated sugars (Leblová-Svobodová and Koštír 1962). Benzyl ITC is a potent inhibitor of plant enzyme activity (Lykkesfeldt and Møller 1993).

ITCs express variable phytotoxicities, a property related to the remainder of the molecular structure. Benzyl ITC inhibits germination and growth of several weeds (Dale 1986; Powell and Spencer 1988; Wolf et al. 1984) at a rate lower than methyl ITC (Teasdale and Taylorson 1986). Two extremes of effectiveness were observed in wheat bioassays at ITC concentrations of $500 \mathrm{ppm}$; butyl ITC had no effect on germination, shoot, or root growth while phenylethyl ITC completely inhibited germination (Bialy et al. 1990). Propenyl, methyl, ethyl, phenyl, and benzyl ITCs were intermediate with respect to inhibition.

In addition to studies with pure compounds, organic solvent extracts of papaya shown to

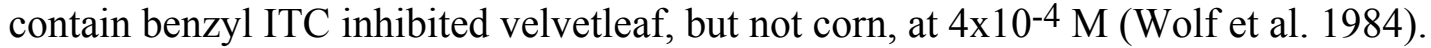
Similarly, $\mathrm{CHCl}_{3}$ extracts of mustard inhibited seedling growth of barley, rye, broccoli, and radish (Jiménez-Orsornio and Gliessman 1987). Barley and rye were most affected; inhibition of radish was not statistically significant. Ethyl acetate extracts of Rorippa indica contained 8-methylsulfinyloctyl, 9-methylsulfinylnonyl, 10-methylsulfinyldecyl, and the corresponding sulfonyl ITCs and inhibited lettuce germination by 90\% (Yamane et al. 1992). Only 10-methylsulfonyldecyl ITC was without activity toward germination and growth.

Inhibitory effects with pure compounds and organic extracts also occur in studies involving volatiles from glucosinolate-containing plant tissues. Volatiles produced from Brassica tissues were shown to inhibit germination and growth of lettuce, wheat, and barnyard grass (Echinochloa crusgalli) (Oleszek 1987). In a separate study, 22 volatile glucosinolate products consisting of ITCs and nitriles were identified in the headspace of chambers containing B. napus seed meal, root, and leaf and stem tissues (Brown and Morra 1995, 1996). Tissues producing those volatiles inhibited germination in bioassays, whereas no inhibition was observed when the same tissues were treated to hydrolyze glucosinolates and remove volatile glucosinolate products before bioassays were initiated. Comparison of headspace volatiles and extracts from the intact and hydrolyzed tissues revealed that ITCs were the most abundant products of intact tissues. The presence of other, nonglucosinolate derived volatiles could not explain inhibition since the same compounds were present in the headspace of intact and hydrolyzed tissues. Some volatile glucosinolate products have also been observed in the headspace of vessels containing B. campestris (1-methylpropyl and 4pentenyl ITC), B. juncea (1-methylpropyl and propenyl ITC), B. nigra (propenyl ITC), and $S$. alba (3-butenyl ITC and phenylethyl CN) (Tollsten and Bergström 1988). Propenyl ITC has 
been detected in headspace of cabbage (Chin and Lindsay 1993) and methyl thiocyanate as a volatile product from broccoli (Hansen et al. 1992).

The effects of volatile ITCs are short-lived. Benzyl ITC was very effective at inhibiting weed germination if the seeds were placed on fresh media; however, if seeds were placed on media two days old, very little difference was observed from the control (Dale 1986). In seed germination bioassays, $50 \%$ of the methyl ITC disappeared within 1-2 $\mathrm{d}$ and the remainder was almost completely gone in 5-7 d (Teasdale and Taylorson 1986).

Many of the overall effects on crop plants can be considered beneficial. Tarahumara Indians in northern Mexico claim that there are fewer weeds in plots after mustard is grown (Jimenez-Orsornio and Gliessman 1987). Ramirez-Villapudua and Munnecke (1987) noted that plots treated with cabbage amendments and solar heating were weed free for months. Potato yield was increased and weed biomass was reduced 50\%-96 \% after rapeseed was incorporated into the test plots (Boydston and Hang 1995). Palouse wheat farmers of the northwestern United States have claimed higher yields after rapeseed was included in the rotation. In Australia, Kirkegaard et al. (1994) measured greater wheat yields following Brassica crops compared to other break crops. Other beneficial effects may result from penetration of the soil by large taproots and suppression of pathogens. However, one potential benefit of glucosinolate-containing plants is weed control by inhibiting seed germination and seedling growth. To take advantage of allelochemic effects in weed suppression, we must consider the mechanisms of plant suppression, characterize the compounds and chemistry involved in this suppression, target weed species, and avoid negative effects on the crop. We must especially consider the potential negative consequences of phytoxicity when targeting pests of horticultural crops.

\section{B. Fungicidal and Bactericidal Activities}

Glucosinolate products may greatly influence fungal and bacterial populations. Although products were not identified, in the presence of myrosinase several alkyl and aryl glucosinolates were cytotoxic to Salmonella typhimurium (Tiedink et al. 1991). ITCs are among the most potent products and are suspected to be the major inhibitors of microbial activity. Benzyl ITC is sometimes used as an antibiotic to treat infections of the respiratory and urinary tracts (Mennicke et al. 1988). Bacteriostatic, bactericidal, and fungicidal effects of many ITCs are well documented (Table 3).

In many cases, microorganisms are differentially inhibited by the same ITC. For example, although methyl ITC is active against a broad range of organisms, dose responses vary tremendously among species. Munnecke et al. (1962) estimated the range of toxicity to Rhizoctonia as 110-1500 $\mu \mathrm{g}$ methyl ITC generated $\mathrm{h}^{-1}$; Myrothecium, 20-490 $\mu \mathrm{g} \mathrm{h}^{-1}$; and Pythium, 10-24 $\mathrm{g} \mathrm{h}^{-1}$. In general, gram-negative bacteria are less susceptible than grampositive bacteria to ITCs; some microorganisms avoid toxicity by degrading the inhibitory compound (Fenwick et al. 1983; Smelt et al. 1989). 
The toxicity and range of activity also vary with changes in the ITC R-group. Greater toxicity is often related to increased volatility (Lewis and Papavizas 1971; Munnecke and Martin 1964). Substituents in the R-group govern solubility, which in general is negatively correlated with activity (Drobnica et al. 1967a, 1967b); however, reasons for differences in toxicity are not always clear. Recent studies of Manici et al. (2000) indicate that ITCs produced from thiofunctionalized glucosinolates such as glucoiberin and glucoerucin are more fungitoxic against Pythium irregulare and Rhizoctonia solani than alkenyl glucosinolate products such as propenyl ITC. This research group proposes that species such as Eruca sativa, Iberis amara, and Rapistrum rugosum may be more effective in controlling fungal pathogens because they contain thiofunctionalized glucosinolates.

Glucosinolate products with nitrile character are biologically active, but effects are more limited than for ITCs. The yeast Nematospora sinecaula is inhibited by butyl thiocyanate at $40 \mu \mathrm{g} \mathrm{mL}^{-1}$ (Holley and Jones 1985) and modified thiocyanates are used to control slime mold in the paper industry (Beekhuis 1975; Wood 1975). However, tests against various microorganisms showed that 2-200 times as much thiocyanate was required to obtain equivalent growth inhibition compared to the corresponding ITC (Virtanen 1965; Walker et al. 1937). Propenyl CN did not inhibit Peronospora at concentrations $>1000 \mu \mathrm{g} \mathrm{mL}^{-1}$ (Greenhalgh and Mitchell 1976). A propenyl cyanide concentration approximately 40 times that of propenyl ITC was required for equivalent inhibition, but benzyl CN inhibited Nematospora at $<50 \mu \mathrm{g} \mathrm{mL}^{-1}$ (Holley and Jones 1985). Solutions of propenyl glucosinolate with myrosinase were more effective at inhibiting Leptosphaeria maculans at $\mathrm{pH} 7$ (where ITC should be the dominate product) than at $\mathrm{pH} 4$ (where the proportion of nitrile product is increased) (Mithen et al. 1986). The same authors showed mild inhibitory effects of 3indolylacetonitrile to L. maculans. 3-Indolylacetonitrile completely inhibited growth of Penicillium chrysogenum at $200 \mu \mathrm{g} \mathrm{g}^{-1}$ (Smissman et al. 1961).

Similarly, other products inhibit microbial activity and growth, though not to the extent of ITCs. OZTs have little effect on the growth of propionic bacteria (Rutkowski et al. 1972) and the fungal pathogen L. maculans (Mithen et al. 1986), but express some activity against Phoma lingam (Schnug and Ceynowa 1990) and Aphanomyces euteiches f. pisi (Smolinska et al. 1997a). 3-Indolylmethanol is quite inhibitory to L. maculans, but ascorbigen and diindolylmethane are only mildly inhibitory (Mithen et al. 1986).

Like OZTs, $\mathrm{SCN}^{-}$has little effect on propionic bacteria (Rutkowski et al. 1972) and the fungal pathogen L. maculans (Mithen et al. 1986). Ammonium thiocyanate inhibits bacterial growth in soil but stimulates fungi at concentrations $>250 \mu \mathrm{g} \mathrm{g}^{-1}$ (Smith et al. 1945). $\mathrm{SCN}^{-}$ inhibits nitrite forming organisms (Smith et al. 1945) and $\mathrm{SCN}^{-}$-containing amitrole-T inhibits nitrification (Van Schreven et al. 1970). Although the effects of $\mathrm{SCN}^{-}$are limited, $\mathrm{SCN}^{-}$often works synergistically with other chemicals. For example, use with certain peroxides produces bacteriocidal solutions, although neither is effective alone (Beekhuis 1975). Similarly, $\mathrm{SCN}^{-}$was more efficient in lysing cells when combined with other anions or lysozymes than when any agent was used alone at the same concentrations (Pollack et al. 1983). 
Activity of aqueous plant extracts against pathogens or other organisms has been observed. Aqueous extracts of mustard (B. campestris) inhibited Verticillium chlamydosporium (Owino et al. 1993) and those of cabbage root inhibited Glomus mosseae spore germination (Vierheilig and Ocampo 1990). B. napus seed meal extracts inhibited A. euteiches (Smolinska et al. 1997a), but slightly enhanced growth of a Propionibacterium (Rutkowski et al. 1972). Buffered seed homogenates of Brassica hirta (S. alba) inhibited growth of Nematospora by more than $99 \%$ (Holley and Jones 1985). Glucosinolates extracted from Brassica kaber and hydrolyzed in aqueous solution with myrosinase inhibited Glomus intraradices (Schreiner and Koide 1993b).

Suppression appears to be related, at least in part, to the solubility of compounds produced by glucosinolates in the tissue. 4-Hydroxybenzyl ITC has greater solubility than many ITCs and would be the most prominent glucosinolate product expected in B. hirta and B. kaber extracts. Several water-soluble glucosinolate products present in aqueous extracts of $B$. napus were inhibitory to A. euteiches (Smolinska et al. 1997a). In contrast, water extracts of cabbage tissues did not suppress Aphanomyces root rot of peas (Papavizas 1966). The dominant ITC in this tissue has low water solubility.

Volatiles from tissues or organic solvent extracts are often highly inhibitory toward microorganisms. These fractions are also most likely to contain highly active ITCs. Extracts of $B$. juncea (in which propenyl ITC is the most prominent product) made with $70 \%$ ethanol and added to growth media at $0.025 \%-0.8 \%$ were in several cases more inhibitory to bacteria than equivalent amounts of propenyl ITC (Kanemaru and Miyamoto 1990). Smaller amounts of other ITCs were also present in the extracts, possibly accounting for the greater toxicity. The authors suggest using mustard as a food preservative. Extracts $\left(\mathrm{CHCl}_{3}\right)$ of $\mathrm{B}$. kaber roots expressed antifungal activity toward Cladosporium cucumerinum and Glomus etunicatum (Schreiner and Koide 1993a). Volatiles from B. kaber were not inhibitory to $G$. intraradices, most likely because relatively nonvolatile 4-hydroxybenzyl ITC is the major glucosinolate product in these tissues. As might be expected from its glucosinolate profile, B. nigra volatiles were inhibitory toward this organism (Schreiner and Koide 1993b). Volatiles from $B$. nigra and B. juncea tissues severely inhibited Fusarium sambucinum (Mayton et al. 1996), from B. napus and B. juncea roots suppressed Gaeumannomyces graminis (Angus et al. 1994), and from B. napus meal completely inhibited A. euteiches (Smolinska 1997b). In all cases, volatile ITCs were implicated as the responsible agents. This effect of volatiles from plant tissues on microorganisms has been termed "biofumigation" (Angus et al. 1994; Kirkegaard et al. 1993).

Studies of pathogen inhibition by glucosinolate-derived allelochemicals have also been described for soils. Cabbage vapors passed through soil columns reduced Rhizoctonia solani contained within that soil (Lewis and Papavizas 1974). Volatiles emanating from cabbageamended soil that were passed through tubes containing Pythium ultimum and Sclerotium rolfsii cultures inhibited growth of the cultures, especially when warmed to $38^{\circ} \mathrm{C}$ (Gamliel and Stapleton 1993). Approximately one-third the incidence of Fusarium infection of oat crowns was observed when soils were covered with heavy $B$. campestris residue compared to light residue applications (Horricks 1969). Sealed vessels containing soil amended with leaf and stem tissue of nine cruciferous species markedly reduced populations of Fusarium 
oxysporum compared to untreated soil and soil amended with alfalfa, wheat straw, chicken manure, or steer manure (Ramirez-Villapudua and Munnecke 1988). Inhibition of Fusarium was diminished or not detectable when cabbage-amended soils were left uncovered, but tissue amendment in combination with solarization was more effective than either solarization or amendment alone (Ramirez-Villapudua and Munnecke 1987).

Detailed investigations of the toxicities of individual isothiocyanates to growth stages of Fusarium oxysporum pathogens in forest nurseries have been conducted in the laboratory. Bioassays with four $F$. oxysporum isolates were conducted using sealed containers in which $0.3 \mu \mathrm{L}$ of 2-propenyl, ethyl, buty, phenylethyl, benzyl, or phenyl isothiocyanate was allowed to volatilize. Propenyl and ethyl isothiocyanates were the most fungistatic of those compounds tested to mycelial growth. Sporulation and conidia viability were not affected by any of the isothiocyanates. However, the same concentrations of propenyl and ethyl isothiocyanates that only inhibited mycelial growth, completely suppressed conidia and chlamydospore germination of all isolates. Other glucosinolates releasing ethyl, benzyl, and phenethyl isothiocyanates were also fungitoxic to $F$. oxysporum conidia and chlamydospores. Changes in populations of the pathogen resulting from a green manure crop will only be achievable if conidia and chlamydospores are targeted, since decreased populations resulting from the direct inhibition of $F$. oxysporum mycelial growth seem unlikely. We concluded that the pathogenic $F$. oxysporum isolates typically infesting nursery soils in northern Idaho will be most suppressed by species of plants containing glucosinolates that release the highest concentrations of propenyl isothiocyanate such as Brassica carinata, B. nigra, and B. juncea (Smolinska et al., 2003).

Although the allelochemicals from glucosinolates are inhibitory to many organisms, incorporated organic matter may simultaneously stimulate microbial populations by providing increased amounts of carbon substrate. Incorporated B. napus residues were less stimulatory than corn residues to Fusarium root diseases in a forest nursery (James, personal communication 2002), but resulted in more disease than fallow treatments (James et al. 1996). This is a major obstacle to using meal amendments to control fungal pathogens in soil. Formulation technologies or amendment strategies must be developed to ensure that pathogen populations are not stimulated.

One of the more thoroughly studied pest inhibition systems includes the use of cruciferous amendments to control Aphanomyces root rot of peas and beans. The results indicate the successes and difficulties commonly encountered in research concerning the biological activity of glucosinolate-containing crops toward plant pests. In greenhouse studies of soils infested with the fungus, Papavizas (1966) tested leaf and stem amendments of several cruciferous plants, of which cabbage was the most effective. Controls contained no amendments. About $70 \%$ of the control plant roots were infected with Aphanomyces; soils amended with as little as $0.5 \%$ dried cabbage leaves showed approximately a tenfold reduction in root infection. The effects were still observed on plantings made 15 weeks after amendment. Interestingly, although Aphanomyces root rot was clearly suppressed, some amended soils actually had increases in Rhizoctonia root rot. 
We suspected that volatile components were the responsible agents, so we tried to analyze headspace vapors above amended soils using aqueous trapping reagents and GC (Lewis and Papavizas 1970). No ITCs were detected in this case, but in contrast to decomposing corn, the vapors included $\mathrm{CH}_{3} \mathrm{SH}$ (thiomethane), $\left(\mathrm{CH}_{3}\right)_{2} \mathrm{~S}$ (dimethyl sulfide), and $\left(\mathrm{CH}_{3}\right)_{2} \mathrm{~S}_{2}$ (dimethyl disulfide). Bioassays showed that these vapors were toxic to Aphanomyces, though much less so than ITC vapors which in some cases were 1000 times more inhibitory. Furthermore, these vapors could be trapped in aqueous solutions, which suppressed root rot only slightly (Lewis and Papavizas 1971; Papavizas and Lewis 1971).

Additional studies of microbial inhibition focused on conditions encountered in the field. In containerized plantings both inside and outside greenhouses, amendments of Brassicaceae tissues significantly reduced Aphanomyces root rot disease beyond fallow and wheatamended treatments by 32\%-38\% (Chan and Close 1987). When Brassicaceae crops were grown in soil instead of being introduced as amendments, reductions averaged $41 \%$. Davis (1988) found in field studies that wheat in rotation had very little effect on Aphanomyces, and that a greater reduction was observed when rapeseed varieties were used. However, neither cropping with rapeseed nor amending with rapeseed tissues resulted in reductions more significant than with oats. In other field studies, similar disease reductions to those observed with rapeseed also occurred with oats and corn (Papavizas and Lewis 1971; Parke and Rand 1989). Root rot severity was reduced in field tests using a white mustard (S. alba) green manure but no difference in yield was observed compared to fallow, perhaps because of reduced pea emergence in white mustard treated plots (Muehlchen et al. 1990). However, continuing a second cycle of peas and white mustard resulted in reduced root rot severity and increased yield in spite of a similar reduction in pea emergence. Careful study of the variables influencing allelochemical efficacy is needed to consistently and effectively control pests.

B. napus meal has been used for pest control in a limited number of studies. Anti-fungal activity against Cylindrocladium parasiticum has been reported (Bhardwaj et al. 1996). The investigators applied 1, 2, or $3 \mathrm{t} \mathrm{ha}^{-1}$ of $B$. napus meal to soil and compared $C$. parasiticum control in peanuts to control by Vapam. The University of Idaho supplied the meal to the investigators. All three rapeseed meal rates reduced disease incidence of Cylindrocladium black rot of peanuts. A maximum 70\% reduction in disease incidence (compared to an untreated control) occurred in the $3 \mathrm{tha}^{-1}$ treatment of peanut cultivar susceptible to the disease. Although glucosinolate concentration of the meal was not mentioned, the concentration was likely less than $50 \mu \mathrm{mol} \mathrm{g}{ }^{-1}$ and thus substantially below what is contained in mustard meals.

Attempts have been made to control other fungal pathogens using meal. Dandurand et al. (2000) used B. napus cv. "Dwarf Essex" meal in laboratory experiments to control Sclerotinia sclerotiorum and A. euteiches. A $100 \%$ reduction in carpogenic germination and a $33 \%$ reduction of myceliogenic germination of $S$. sclerotiorum occurred in soil amended with Dwarf Essex meal. A low glucosinolate B. napus meal (Stonewall) reduced carpogenic germination by $44 \%$ and had no effect on myceliogenic germination, indicating that glucosinolate hydrolysis products were critical to suppression. A. euteiches root rot of pea was reduced $77 \%$ by Dwarf Essex meal and was unaffected by low glucosinolate Stonewall 
meal. In all experiments meal was not homogeneously incorporated into the soil, but was placed on the bottom of the bioassay container and separated from the overlying soil by sterile fiberglass cloth.

In summary, fungal and bacterial pathogens can likely be controlled by glucosinolatecontaining meals. Previous research was conducted most often with B. napus meal containing glucosinolate concentrations less than $50 \mu \mathrm{mol} \mathrm{g}^{-1}$ tissue. Higher concentration glucosinolate meals will be more effective. Experimentation must be conducted to determine whether the additional carbon contributed from the meal exerts a growth-promoting effect on the fungal pathogens, thereby decreasing the pesticidal efficacy of the meal. Amendment techniques or formulations must be optimized to decrease growth promotion of the pathogen.

\section{Allelochemical Effects on Insects and Other Invertebrates}

As with other organisms, organic extracts of glucosinolate-containing plant tissues have marked effects on insects. Usually extracts are placed on a medium such as filter paper and the solvent is evaporated (controls contain solvent only). Lichtenstein et al. (1964) found root extracts of Brussels sprouts to be very toxic to Drosophila melanogaster, as demonstrated by $50 \%$ mortality in $10 \mathrm{~min}$. Macerated root tissue was quite toxic also; $50 \%$ mortality in $3 \mathrm{~h}$ for Drosophila and 50\% mortality in $24 \mathrm{~h}$ for the common housefly Musca domestica. Toxicity was in most cases strongly correlated with phenylethyl ITC content. Tissues that produced mortalities but did not possess phenylethyl ITC produce other ITCs.

Insecticidal activity of several ITCs has been demonstrated, especially for aromatic compounds (Åhman 1986; Borek et al. 1995b; Chew 1988a; Lichtenstein et al. 1962, 1964; Seo and Tang 1982; Wadleigh and Yu 1988). Borek et al. (1995b) tested the toxicities of six commercially available ITCs to eggs of the black vine weevil (Otiorhynchus sulcatus (F.)) and concluded that aromatic ITCs were most toxic. Later the same group of investigators showed using an expanded set of 12 ITCs and QSAR relationships that ITC polarity was most important in explaining observed toxicities (Borek et al. 1998). Using a linearstructure-activity relationship they predicted that the highest contact toxicities of ITCs to black vine weevil eggs will occur from glucosinolates producing ITCs with higher numbers of carbon atoms or those bearing sulfinyl, thio, or aromatic moieties.

Whitefringed weevil larvae (Naupactus leucoloma) were used as bioassay organisms to test the toxicity of volatile and nonvolatile glucosinolate hydrolysis products (Matthiessen and Shackleton 2000). Comparisons of the toxicity of two pure ITCs in the headspace of sealed containers showed that methyl ITC vapors were more toxic than phenylethyl ITC across a temperature range of $5^{\circ}-20^{\circ} \mathrm{C}$. The toxicity of volatiles from $B$. juncea meal (assumed to be propenyl ITC) were more toxic than those from $B$. napus meal when equal weights of the tissues were compared. Water-soluble products displayed no toxicity to weevil larvae.

In screening products to protect seedling corn from injury by southern corn root worm (Diabrotica undecimpunctata howardi), propenyl ITC killed the worm but also prevented the corn seeds from germinating (Landis and Gould 1988). Methyl ITC is mainly used to control 
various fungi that cause damping off and root rot, but is also used to control insects such as wireworms and symphilids, and nematodes (Beekhuis 1975; Mullins and Kirkbright 1987; Sirons 1973; Toba 1984; Worthing 1987). Propenyl ITC was the most effective of 57 volatile compounds tested against the wireworms Limonius californicus and Limonius canus, with an $\mathrm{LC}_{50}$ of $2.33 \mu \mathrm{g} \mathrm{mL}^{-1}$ (Lehman 1942). Rapeseed meal amended (3\% on a weight basis) to soil repelled wireworms (L. californicus), but in uncovered containers did not kill them (Brown et al. 1991). Maximum total ITC content of $301 \mathrm{nmol} \mathrm{g}^{-1}$ soil decreased rapidly. Subsequent testing using propenyl ITC in the same soil showed that wireworms were killed in lower but similar concentrations in capped vials $\left(\mathrm{LC}_{50}\right.$ range $211-238 \mathrm{nmol} \mathrm{g}^{-1}$ soil) and that propenyl ITC added to soil was more persistent than ITC produced from the rapeseed meal-amended soil in the previous test (Williams et al. 1993). However, glucosinolate products like ITCs are not always toxic to insects at concentrations found in plant tissues. In fact, ITCs can act as cues or even attractants influencing the behavior of certain insects (Finch and Skinner 1982; Pivnick et al. 1991; Rodman and Chew 1980; Traynier and Truscott 1991).

Other glucosinolate hydrolysis products have insecticidal properties as well. Organic thiocyanates have been used in insecticides to control weevils in grain and to produce quick knockdown of flying insects such as flies, and have a relatively low impact on mammals (Beekhuis 1975; Wood 1975). 3-Indolylacetonitrile, known more for its auxin-like activity on plants, also inhibits growth of insects (Smissman et al. 1961). $\mathrm{SCN}^{-}$is ineffective when used alone, but is insecticidal in combination with other chemicals (Beekhuis 1975). $\mathrm{SCN}^{-}$ was toxic to wireworms only at concentrations much higher than observed in rapeseed mealamended soil (McCaffrey et al. 1995).

Invertebrate plant pests other than insects are also potential targets. Winkler and Otto (1980) found that rotational plantings of rape or mustard in strawberries checked the spread of some nematodes, particularly Pratylenchus penetrans. Leguminosae, potato, or grass rotations did not alter nematode populations, although green manure applications of Leguminosae (peas, beans and vetch), rape, or mustard reduced nematode numbers. Similarly, growing rapeseed in soil and incorporating the tissue as a green manure significantly reduced populations of Meloidogyne chitwoodi compared to fallow (Mojtahedi et al. 1991), although results were not as clear in a study involving Meloidogyne incognita and Meloidogyne javanica (Johnson et al. 1992). In the presence of myrosinase, glucosinolates are toxic to Heterodera schachtii at concentrations of 0.5-5.0 $\mathrm{mg} \mathrm{mL}^{-1}$ (Lazzeri et al. 1993). Some varieties of Brassica crops are being offered commercially as "trap crops" for nematodes. Rather than killing the nematodes, Brassica plants interfere with nematode reproductive cycles. Biochemical mechanisms responsible for nematode resistance and suppression, although not well understood (Lazzeri et al. 1993), deserve further attention.

Rapeseed meal has been used as a soil amendment in an attempt to control nematodes. Investigators applied 1, 2, or $3 \mathrm{tha}^{-1}$ of $B$. napus meal to soil and compared control of the soybean cyst nematode (Heterodera glycines Ichinohe) in soybean to chemical control by aldicarb (Bhardwaj et al. 1966). The University of Idaho supplied the meal to the investigators. The results were ambiguous, and acceptable control was not achieved. Higher glucosinolate concentration meals are thus necessary to control this plant pest. 


\section{Management Considerations}

The evidence strongly supports the idea that glucosinolate degradation products are biologically active and have considerable potential for use in pest control strategies. However, many factors must be considered when these strategies are implemented if we are to take full advantage of this natural pesticidal activity. Release efficiency and release rate from plant tissues, susceptibility of the target species, effectiveness of the particular glucosinolate degradation product, soil texture, organic matter, $\mathrm{pH}$, moisture content, and effectiveness of the products in the aqueous and vapor phases all contribute to pesticide efficacy.

Understanding the processes and fates of the allelochemicals in soil is crucial for maximizing potential benefits in pest control and minimizing potential negative environmental impacts. Soils and soil/plant interactions may influence which products are formed and their effectiveness in the soil environment. Although additional work is necessary in this area, enough data have been collected to make some observations and generalizations concerning the behavior of several glucosinolate products in soil.

\section{A. Product Formation}

Conditions affecting product formation during glucosinolate degradation have most often been examined in isolated plant tissue systems. For pest control, however, we are particularly interested in what happens in soil. As discussed in previous sections, the plant's glucosinolate profile and characteristics of the solution in which hydrolysis takes place control qualitative aspects of product formation. When plant tissues are incorporated into soil, the soil's influence on product formation may be linked as much to its moisture content as other soil characteristics. Under drier conditions little soil solution is available to influence the reaction, and the effects of $\mathrm{pH}$ and metal ions on product formation could be determined solely by the reaction microenvironment of the plant tissue. However under more moist or wet conditions, the soil solution and soil colloids are much more likely to participate in reactions that alter product formation.

Glucosinolate products such as ITCs, $\mathrm{SCN}^{-}$, OZTs, and to a lesser extent nitriles are produced in soil amended with plant tissue (Brown et al. 1991, 1994). Nine glucosinolate degradation products - five ITCs, three nitriles, and one OZT - were identified in field soils extracted after a B. napus plow-down (Gardiner et al. 1999). The most abundant products were 2-phenylethyl ITC and benzenepropanitrile. ITCs have also been collected in the rhizospheres of a few plants (Tang and Takenaka 1983; Yamane et al. 1992), including $B$. napus (Kirkegaard et al., 2001).

A model system using propenyl glucosinolate and myrosinase amendments was used to investigate product formation in six soils at two moisture contents of field capacity $(0.033$ $\mathrm{MPa}$ ) and saturation. Propenyl ITC was produced as the dominant product regardless of soil characteristics (Borek et al. 1994). Only minor amounts of propenyl CN were detected. 
Sinigrin and myrosinase added to unbuffered aqueous soil extracts resulted in greater proportions of nitrile, and in some cases nitrile became the dominant product. Glucosinolate hydrolysis produces $\mathrm{H}^{+}$, decreasing solution $\mathrm{pH}$ as the reaction proceeds. Although this enhances nitrile formation in unbuffered extracts, soils provide a large buffering capacity that in effect prevents nitrile formation. None of these soils were more than moderately acidic ( $\mathrm{pH}$ of 5.65-8.3), so glucosinolate hydrolysis in wet acidic soils $(\mathrm{pH}<5$ ) may result in more nitrile formation. Conditions favoring production of ITCs could be advantageous for pest control since these are typically the most biologically active products.

Additionally, product release rates and efficiencies must be considered. Although lower in total glucosinolate content, root and shoot tissues of B. napus realeased volatile products more efficiently than did meal tissue (Brown and Morra 1995, 1996). The condition of the tissue is also important. Fresh tissues may release products more slowly than those physically disrupted before amendment by tissue crushing, air drying, freeze drying, or grinding. Lower maximum concentrations are thus likely to be produced from fresh tissue, but the period of release is potentially extended. Recent investigations indicate that maceration of green tissues is indeed necessary to maximize ITC release (Morra and Kirkegaard 2002). Such a limitation does not exist when using meal amendments as soil additives since the seed crushing procedure has resulted in extensive cellular disruption.

\section{B. Product Activity and Fate}

\section{Lifetimes}

Lifetimes of glucosinolate products in the environment are generally short, an advantage when considering environmental impact. ITCs remain in soil for a few days to a few weeks. Even in gas-tight containers, half-lives of methyl ITC in several soils were $0.5-50 \mathrm{~d}$ at $15^{\circ} \mathrm{C}$ (Smelt et al. 1989). Concentrations of methyl ITC in greenhouse air, where soil had been amended with metham-sodium, were reduced to less than $0.2 \%$ of the original amount by the third day (Van Den Berg et al. 1992). One week after a major spill of metham-sodium into the Sacramento River of California, neither metham-sodium nor the methyl ITC hydrolysis product was detectable (del Rosario et al. 1994). In a germination test $80 \%$ of the inhibitory capacity of propenyl ITC in soil was gone after 2 weeks (Bell and Muller 1973). Other research showed that the half-life of propenyl ITC in six soils was 20-60 h; propenyl CN had a longer half-life of 80-100 h. The average half-life in all six soils was $48 \mathrm{~h}$ for propenyl ITC and $96 \mathrm{~h}$ for propenyl CN (Borek et al. 1995a). Biological effects of volatile ITCs should be short-lived, especially in uncovered soils. The potential for negative environmental consequences is therefore quite small and is illustrated by the fact that no methyl ITC residues were detected in more than 200 surface water samples (Hogendoorn et al. 1992). However, a short residence time places limits on achieving effective pest control and may contribute to the variability observed in the suppression of soil-borne plant pests.

Lifetimes of allelochemicals produced in situ in plant tissue-amended soil differ from those of the respective pure chemicals amended to soil without plant tissue. Ninety percent of the maximum ITC in rapeseed meal-amended soil dissipated within $24 \mathrm{~h}$ (Brown et al. 1991), 
whereas only $60 \%$ of propenyl ITC amended in the form of an aqueous phase mixture to the same soil was lost in $24 \mathrm{~h}$ (Williams et al. 1993). This is consistent with the finding that an average of $30 \%$ propenyl ITC, when added in pure form, was lost in six soils during a $24 \mathrm{~h}$ period (Borek et al. 1995a). Accelerated dissipation of ITC thus occurs in the presence of plant tissue amendments, most likely because of sorption to the additional organic carbon.

Lifetime of $\mathrm{SCN}^{-}$in soil is also relatively short. Losses of $\mathrm{SCN}^{-}$in four soils were $40 \%-95 \%$ over a six-day period (Brown and Morra 1993). In contrast to ITC, however, $\mathrm{SCN}^{-}$produced in situ in rapeseed meal-amended soil dissipates more slowly, having an extended lifetime in the presence of such tissues (Brown and Morra 1993; Brown et al. 1991). Adding propenyl ITC along with solutions of $\mathrm{SCN}^{-}$to soil inhibited $\mathrm{SCN}^{-}$loss, demonstrating that combinations of glucosinolate products may alter the behavior of individual products in soil. In this case, propenyl ITC most likely inhibited microbial activity and the corresponding microbial degradation of $\mathrm{SCN}^{-}$.

\section{Volatilization}

ITC disappears via many routes; volatile losses are one major route. Unsealed bottles had much greater losses of methyl ITC than sealed bottles (Ashley et al. 1963). Thirty-four percent of the methyl ITC in spiked soil was recovered in an air stream passing through it, and nearly all of that within $10 \mathrm{~h}$ (Munnecke et al. 1962). Vapor pressures for methyl ITC have been reported as 13 and $20.7 \mathrm{~mm} \mathrm{Hg}$ at $20^{\circ} \mathrm{C}$, relatively low values for a fumigant (Sirons 1973; Smelt and Leistra 1974); thus, volatile losses may be less of a problem for ITCs than for some commercial products. However, volatilization is important for even distribution of fumigants in soil. Vapor pressures of various ITCs and nitriles vary widely, so large differences in soil fumigation resulting from glucosinolate hydrolysis products are expected.

Loss of ITC into the atmosphere is not desirable, since that amount of product is not available for pest inhibition. Volatile losses could also be of concern for health and environmental reasons. Photodissociation by sunlight appears to be one rapid and effective pathway for removing methyl ITC from the atmosphere, taking about $41 \mathrm{~h}$ (Alvarez and Moore 1994). This process would likely apply to other ITCs; however, questions remain as to the fate and impact of dissociation products (Geddes et al. 1995).

\section{Organic Matter}

Many fumigants are less effective in soil than in nonsoil systems. This is particularly true of ITCs. Propenyl ITC was about 193 times more toxic to wireworms than $\mathrm{CS}_{2}$ (carbon disulfide) in air, but was only about 29 times more toxic in a silt-loam soil (Lehman 1942). Similar results were found with methyl ITC compared to $\mathrm{CS}_{2}$ and other fumigants (Matthiesson et al. 1996). Phytotoxicity to wheat from Brassica residues or extracts was generally greater when wheat was grown in sand than in soil (Mason-Sedun and Jessop 1988). 
Sorption of ITCs to soil constituents is an important mechanism that decreases ITC effectiveness. Sorption of methyl ITC to soil increases with increasing organic matter content (Munnecke and Martin 1964; Smelt and Leistra 1974). As a result, much less methyl ITC is extractable from organic muck soils than from mineral soils (Sirons 1973). Although Ashley et al. (1963) determined that the disappearance of extractable methyl ITC was slowest in a peat soil amended with metham-sodium, amounts of extractable ITC could have been controlled by metham-sodium hydrolysis rates instead of ITC sorption. As generally observed for methyl ITC, increased propenyl ITC disappearance from soil is correlated with greater organic carbon contents and typically greater nitrogen contents (Borek et al. 1995a). This trend was not apparent for the corresponding nitrile. Faster ITC disappearance likely results from greater reactivity with nucleophilic groups commonly found in soil organic matter such as alcohols, phenols, thiols, carboxylic acids, and amines. These types of reactions may also explain reduced efficiency of volatile ITCs released from seed meal tissue compared to other plant tissues (Brown and Morra 1996). Amino groups in protein, contained in high concentration in rapeseed meal, readily react with ITCs (Björkman 1973; Kawakishi and Kaneko 1987) and reduce measured volatile concentrations.

\section{Temperature}

Methyl ITC sorption to soil is not greatly enhanced by increasing the temperature from $4^{\circ}$ to $30^{\circ} \mathrm{C}$ (Matthiessen et al. 1996), although elevated temperatures are correlated with increased amounts of ITC in the vapor phase and faster rates of disappearance from soil (Ashley et al. 1963; Borek et al. 1995a; Turner and Corden 1963). Increased temperature was also associated with a greater inhibitory effect toward pathogenic fungi in a covered cabbageamended soil (Gamliel and Stapleton 1993), probably because of more thorough fumigation. Greater concentrations of volatile thiomethane, dimethyl sulfide, and propenyl ITC were observed at elevated temperatures. Temperature influences the fate of nonvolatile products as well. For example, higher temperature generally increased disappearance rates of $\mathrm{SCN}^{-}$ in soil (Brown and Morra 1993).

\section{Water}

Aqueous solubilities control ITC partitioning in the three-phase soil system. Methyl ITC has reported solubilities in water of $7.6 \mathrm{mg} \mathrm{mL}^{-1}$ (Sirons 1973) and $8.9 \mathrm{mg} \mathrm{mL}^{-1}$ (Smelt and Leistra 1974) at $20^{\circ} \mathrm{C}$. Estimates of methyl ITC distribution between the vapor, aqueous, and solid phases of soil indicate that most of the ITC is in the aqueous phase under moist conditions, with a substantial amount retained in the solid phase (Smelt and Leistra 1974). Although ITC in solution still has biological activity, uneven distribution in soil is likely caused by localized concentrations and reduced diffusion (Leistra et al. 1974). This heterogeneity could contribute to variations in effectiveness. We do not know whether ITCs such as 4-hydroxybenzyl ITC with greater water solubility would have greater pesticidal activity than more volatile and less soluble ITCs under wet conditions. Methyl ITC was susceptible to leaching with high moisture in sandy soil (Frick et al. 1995), therefore, other ITCs may leach in permeable soils subjected to large water inputs. Henry's constants must therefore be determined for the ITCs of interest to better predict partitioning within the threephase S soil environment. 
Increased water content increases ITC longevity in soil. More methyl ITC was measured in headspace of soils with lower water contents and rates of disappearance were more rapid (Turner and Corden 1963). Although 30\% of applied methyl ITC was lost by volatilization under a drier moisture regime, very little vapor phase methyl ITC was lost during a wet regime (Frick et al. 1995). Increased water content increased the half-life of propenyl ITC (Borek et al. 1995a). Thus continually wet conditions, especially when combined with cold temperatures, could result in increased ITC lifetimes and perhaps increased potential for pest inhibition resulting from longer exposure times. This could also extend the risks of residual effects on subsequent plantings.

In contrast to ITC, increased soil moisture content accelerates the disappearance of propenyl CN (Borek et al. 1995a). The fates of ITCs and organic nitriles in soil, at least in the case of propenyl derivatives, appear to be controlled by different mechanisms. Propenyl CN is sorbed or reacts more quickly at the water phase than at the gas phase, which may indicate that the overall reaction rate for nitriles is controlled by the gas/water phase partition coefficient.

\section{Soil Texture}

Volatile losses are greatest from coarse textured soils, but texture is less important than factors such as organic carbon content. In a comparison of three soils, volatile loss of methyl ITC was greatest from a sandy loam $(0.67 \%$ organic matter, $8 \%$ clay); least volatilization occurred from a loam with more clay but also greater organic matter $(2.03 \%$ organic matter, $25 \%$ clay). The finest textured soil, a clay loam ( $0.55 \%$ organic matter, $40 \%$ clay), had intermediate losses of methyl ITC compared to the other two soils (Munnecke and Martin 1964). Extractable concentrations of methyl ITC obtained from sandy, clay, and loam soils amended with metham-sodium are similar for the first few hundred hours (Ashley et al. 1963). As such, evidence suggests that sorption to soil clay is not a major mechanism of disappearance for ITCs. In contrast, sorption to or degradative catalysis by inorganic soil constituents may play a role in $\mathrm{SCN}^{-}$disappearance from soil, particularly at higher temperatures (Brown and Morra 1993).

\section{7. $\mathrm{pH}$}

Soil $\mathrm{pH}$ influences the formation and disappearance of glucosinolate hydrolysis products, although effects on disappearance are not dramatic. Greater amounts of methyl ITC were trapped in headspace from soils adjusted to a higher than to a lower $\mathrm{pH}$ (Munnecke and Martin 1964), and additing lime to three soils tended to shorten residence times of methyl ITC in soil (Ashley et al. 1963). No correlation between soil $\mathrm{pH}$ and propenyl ITC or propenyl $\mathrm{CN}$ disappearance was observed for six soils ranging in $\mathrm{pH}$ from 4.35 to 9.10 (Borek et al. 1995a). Typical $\mathrm{pH}$ values of agricultural soils are thus not expected to greatly alter allelochemical residence times. 


\section{Microbial Activity}

Microbial degradation may also be responsible for the disappearance of glucosinolate hydrolysis products. Soil sterilized with heat and soil extracts sterilized by filtration or heating slowed the disappearance of methyl ITC in sealed bottles (Ashley et al. 1963). Accelerated loss of methyl ITC after successive soil applications has been demonstrated in field and laboratory studies (Smelt et al. 1989).

Although microbial degradation is suggested by these data, this is not a consistent observation. For example, attempts to sterilize soil by autoclaving or ethyleneoxide treatment did not change disappearance rates of propenyl ITC (Borek et al. 1995a). The same soil treatments increased propenyl CN half-life only slightly. In contrast to soils that appear to have enhanced degradation, a second treatment of fumigant to soil did not enhance ITC disappearance (Ashley et al. 1963) and two soils treated at least 13 times showed no increase in the ITC disappearance rate (Smelt et al. 1989). Similarly, five additions of propenyl ITC or propenyl $\mathrm{CN}$ during a period of $10 \mathrm{~d}$ failed to alter the half-lives of these chemicals (Borek et al. 1995a). No clear evidence demonstrates that biotic transformation controls the fate of ITCs in soil. The relative importance of microbial activity in the degradation of organic nitriles is also unclear, although biotic degradation is probable. Numerous microorganisms have been isolated that degrade aliphatic nitriles and a few that degrade aromatic nitriles (Nawaz et al. 1991, 1992).

Several bacteria have been identified that degrade $\mathrm{SCN}^{-}$(Betts et al. 1979; Happold et al. 1958; Katayama and Kuraishi 1978; Putilina 1961; Smith and Kelly 1988; Stafford and Callely 1969). SCN- is rapidly broken down, and a flush of growth after breakdown results from the added nitrogen source (especially for $\mathrm{NH}_{4} \mathrm{SCN}$ ). Even after temporary sterilization with $897 \mathrm{~kg} \mathrm{NH}_{4} \mathrm{SCN}$ ha-1 marked stimulation of plant growth began to occur after $69 \mathrm{~d}$ (Beekhuis 1975). Other investigations showed that autoclaving soils before incubation and adding $\mathrm{NaN}_{3}$ or propenyl ITC slowed $\mathrm{SCN}^{-}$disappearance (Brown and Morra 1993). Disappearance of $\mathrm{SCN}^{-}$was correlated with organic carbon content of soils when temperatures were at or below $30^{\circ} \mathrm{C}$. This suggests that $\mathrm{SCN}^{-}$losses are related to the amount of carbon available to support microbial activity rather than $\mathrm{SCN}^{-}$sorption to the organic carbon fraction of the soil.

Results for methyl ITC and propenyl ITC discussed throughout this section are not necessarily the same as for other ITCs because of the influence of the R group chemistry. Different $\mathrm{R}$ groups affect volatility and solubility, resulting in altered biological activities. As a consequence, individuals involved in efforts to develop plant varieties for pest control should consider glucosinolate type as well as total glucosinolate concentration. 


\section{Additional Allelochemicals}

Numerous other S-containing compounds, mainly volatiles, have been identified as secondary products of glucosinolates in cruciferous tissues. Methanethiol, dimethyl sulfide, and dimethyl disulfide are produced in cabbage-amended soils (Gamliel and Stapleton 1993). Although these compounds possess lower toxicities than ITCs (ITCs $>$ thiols $\cong$ thiocyanates $>$ sulfides), they are produced in larger amounts and for much longer periods than propenyl ITC (Gamliel and Stapleton 1993; Lewis and Papavizas 1971; Virtanen 1965; Walker et al. 1937). Greater total amounts and longer production times may compensate for lower toxicities, increasing the potential importance of these compounds in pest inhibition.

Several of these S-containing compounds may result from abiotic or biotic degradation of primary glucosinolate hydrolysis products. Two water soluble degradation products of 4methylthio-3-butenyl ITC, one identified as 2-thioxo-3-pyrrolidinecarbaldehyde, were fungicidal (Uda et al. 1993). Some smaller molecular weight products might be explained by the simple loss of a part of the molecule such as methanethiol from thioalkyl ITC (Uda et al. 1990). Other compounds, including $\mathrm{COS}, \mathrm{H}_{2} \mathrm{~S}$, and $\mathrm{CS}_{2}$ are formed from ITCs by a series of hydrolysis reactions (Bailey et al. 1961; Challenger 1959; Dateo et al. 1957). Alternatively, $\mathrm{H}_{2} \mathrm{~S}$ so generated might react with $\mathrm{CO}_{2}$ and produce COS (Shaw et al. 1980). Aerated and waterlogged soils amended with $\mathrm{SCN}^{-}$produced $\mathrm{COS}$ via an unknown mechanism (Minami and Fukushi 1981). Only COS was produced in a waterlogged soil amended with $\mathrm{SCN}^{-}$, although samples were monitored for $\mathrm{H}_{2} \mathrm{~S}, \mathrm{CH}_{3} \mathrm{SH}, \mathrm{CH}_{3} \mathrm{SCH}_{3}, \mathrm{CS}_{2}$, and $\mathrm{CH}_{3} \mathrm{SSCH}_{3}$ (Minami 1982). Bending and Lincoln (1999) suggest with respect to fresh tissues that other volatile $S$ compounds were likely to be as important in pest control as ITCs. Further information regarding reaction pathways would enhance our ability to predict and optimize pest control efficiency.

Other compounds besides products of glucosinolate degradation may be biologically active and thus contribute to pest inhibition. For example, S-containing indole compounds found in B. campestris and B. oleracea are not derived from glucosinolates and act as phytoalexins (Monde et al. 1991; Takasugi et al. 1988). In addition, phenolic compounds are sometimes suspected as biologically active agents in cruciferous plants (Kutácek 1964), a possibility since seed meals of some Brassica contain relatively higher phenolic compound concentrations than other sources (Shahidi and Naczk 1992). Given the ubiquitous nature of phenolics, biological activity may be related more to quality than quantity (Levin 1971; Singleton and Kratzser 1973). Although phenolics are often suggested to participate in plant defenses against infection, little work appears to have been done on the potential pesticidal activity of specific phenolics in Brassica seed meals.

Additional inhibitory compounds may be produced by breakdown of the S-containing amino acids methionine and cysteine. Compounds such as methanethiol, dimethyl disulfide, and dimethyl trisulfide are derived from the non-protein amino acid $S$-methyl-1-cysteinesulfoxide (SMCSO) via a methyl methanethiosulfinate intermediate (Chin and Lindsay 1994; Marks et al. 1992; Maruyama 1970; Ostermayer and Tarbell 1960). The intermediate is produced 
either enzymatically by cysteine sulfoxide lyase or nonenzymatically under acidic conditions. SMCSO constitutes $0.25 \%-2 \%$ (dry weight) of the tissue in Brassica plants (Gosden 1979; Marks et al. 1992), which indicates that contributions to pesticidal activity could be significant. Ensiled forage rape (B. napus) contained approximately $83 \%$ of the original SMCSO content, but only one-tenth the original glucosinolate content (Fales et al. 1987), suggesting SMCSO may be less susceptible to rapid degradation and thus remain available for longer time periods.

In some cases, methanethiosulfinate is proposed to react with $\mathrm{H}_{2} \mathrm{~S}$ to form thiols and sulfides (Chin and Lindsay 1994). Any $\mathrm{H}_{2} \mathrm{~S}$ produced from ITCs could thus react with SMCSO products to form yet additional allelochemicals. Optimal pest inhibition may require combined interactions of glucosinolate products, SMCSO products, and additional compounds produced by reactions between components of these two pools. Various products could be formed simultaneously or sequentially, with one suite of biologically active compounds replacing another during an extended period. Effects on nematodes have been observed to last several weeks (Santos and Mojtehedi, personal communication) suggesting the involvement of other compounds beyond the active lifetime of volatile ITCs.

\section{Glucosinolate Concentrations}

Yield data for many plant/soil/pest systems suggest that glucosinolate concentrations are, or border on being, sufficient for pest control. Efforts to develop plants with high glucosinolate levels for pest control are worthwhile. Since the traditional approach of plant breeders has been to select for reduced concentrations of glucosinolates, concentration increases are likely. Eventually perhaps, particular strains of plants with specific glucosinolate profiles could be developed for specific targets susceptible to the respective glucosinolate products.

Breeding may not be the only means to increase product concentration. Some limited increases in resistance have been achieved by applying synthetic ITC precursors to Brassica plants (Dawson et al. 1993; Griffiths et al. 1989). Methyl jasmonate and salicylic acid, other compounds that occur naturally, have been associated with increased levels of certain glucosinolates in leaves when applied to those tissues (Doughty et al. 1995; Kiddle et al. 1994). Perhaps glucosinolates could be applied to plant surfaces in a resistance strategy or to the soil (combined with myrosinase) for pest suppression. Although synthetic inputs would not be eliminated, reductions might be achieved by supplementing plowed-under plant tissues with low levels of commercial ITC-producing fumigants.

Although data are limited, we can look quantitatively at the question of glucosinolate concentrations and the potential to control plant pests. The amount of methyl ITC recommended for soil applications using sodium $\mathrm{N}$-methyldithiocarbamate can be estimated by assuming a $15.2 \mathrm{~cm}$ depth of incorporation, soil bulk density of $1.4 \mathrm{~g} \mathrm{~cm}^{-3}$, and $100 \%$ conversion to methyl ITC (Brown et al. 1991). Calculated values were 517-1294 nmol methyl ITC $\mathrm{g}^{-1}$ soil depending on the crop and type of control required. These are higher than the amount of ITC (301 $\mathrm{nmol} \mathrm{g}^{-1}$ soil) observed in soil amended with rapeseed mealamended at a rate of $3 \%(\mathrm{w}: \mathrm{w})$ (Brown et al. 1991). To kill 50\% of wireworms ( $L$. 
californicus), rapeseed meal had to be amended at a rate of $114 \mathrm{~g} \mathrm{~kg}^{-1}$ soil (Elberson et al. 1996), too high to be useful. However, the same level of control for black vine weevil (Otiorhynchus sulcatus) required only $19 \mathrm{~g}$ rapeseed seed meal kg-1 soil (Borek et al. 1996b).

The previous studies were performed with rapeseed meal having a glucosinolate concentration near 40-50 $\mu \mathrm{mol} \mathrm{g}^{-1}$ tissue. Complete release of glucosinolate to ITC has not been observed (Brown et al. 1991; Brown and Morra 1995). Instead, the data indicate that a maximum of $20 \%$ of the glucosinolate will be released as ITC from rapeseed meal (Brown et al. 1991). If we now assume similar release efficiencies for mustard meals that contain glucosinolate concentrations of $250 \mu \mathrm{mol} \mathrm{g}^{-1}$ tissue, we can estimate the amount of meal necessary to approach the recommendations application rates for commercially available ITC fumigants (517-1294 nmol methyl ITC $\mathrm{g}^{-1}$ soil). A 1\% (w:w) meal amendment to soil of a meal containing $250 \mu \mathrm{mol}$ glucosinolate $\mathrm{g}^{-1}$ tissue would result in the release of $500 \mathrm{nmol}$ ITC $\mathrm{g}^{-1}$ soil. We are now at the lower limit of what is considered necessary for soil sterilization. Doubling the amendment rate to $2 \%(\mathrm{w}: \mathrm{w})$ would increase predicted ITC release to $1000 \mathrm{nmol} \mathrm{g}^{-1}$ soil and thus achieve a concentration considered near the upper limit of that recommended for commercial fumigants. Thus, meals with glucosinolate concentrations in excess of $200 \mu \mathrm{mol} \mathrm{g}^{-1}$ tissue may indeed be effective in pest control at practical tissue amendment rates.

\section{E. Timing}

Length of exposure to the allelochemical is one variable associated with timing. Lewis and Papavizas (1971) showed in sealed containers that concentrations failing to kill microorganisms in $2 \mathrm{~d}$ might kill them in 4-6 d. Evidence indicates similar results with insects and seeds (Lichtenstein et al. 1962, 1964; Pieczarka and Warren 1960). Dormant seeds making up the seed bank in soil and exposed to root exudates over a period of time could be more susceptible to inhibition than introduced seeds exposed to root exudates for only a short time.

Another important variable is the time when initial exposure occurs; in other words, the time when the target organism is introduced to the glucosinolate-containing tissue. Pea seeds planted immediately after soil amendment with cabbage did not germinate. Peas planted 3 weeks later showed some reduction of growth if fresh leaves were used, but not if air-dried leaves were used. Plantings after 7 weeks showed no growth reduction or slight growth enhancement (Papavizas 1966). Only fresh cabbage juice inhibited lactic acid (Leuconostoc mesenteroides) bacterial growth (Kyung and Fleming 1994). Inhibition of germination and plant growth by ITCs was most effective when the chemicals were applied to seeds or applied within the first 3 d of the germination period (Leblová-Svobodová and Koštír 1962).

Timing maximal glucosinolate product formation with a susceptible life stage of the target organism may be necessary. Glucosinolate concentrations in plants usually start out low, climb with fluctuations to some maximum, then drop off near the time of plant senescence (Freer et al. 1989; Griffiths et al. 1991; Macfarlane-Smith and Griffiths 1988). Aqueous extracts of wild mustard were most effective at inhibiting growth when extracts were made 
during the bolting and flowering stage (Jiménez-Orsornio and Gliessman 1987). Coplantings of Brassica plants with other plants do not inhibit seed germination or plant growth (Bell and Muller 1973; Choesin and Boerner 1991), perhaps because plant stages susceptible to inhibition are past by the time sufficient glucosinolate products are present. In the case of coplanting with two Brassica species, planting wild mustard with broccoli resulted in higher broccoli yields, but wild mustard planted before broccoli inhibited broccoli yield (JiménezOrsornio and Gliessman 1987). In a consistent fashion, insects and microorganisms may be more susceptible at certain stages in their life cycle. Relatively sudden releases and higher concentrations of products from amendments timed to susceptible stages of an organism's life cycle would be most effective.

\section{F. Additional Benefits}

Other benefits may be obtained by using glucosinolate-containing plants in pest control strategies. For example, soil structure is improved by use of organic amendments and high root development like that in oilradish and mustard is important to prevent soil erosion and nitrate leaching. Reports in the literature also indicate that B. napus is efficient at absorbing phosphorus from deficient soils (Grinsted et al. 1982; Hedley et al. 1982b). In addition, plant tissue amendments can serve as nutrient sources and high protein-containing rapeseed meal may be used as a supplementary nitrogen source (Johansson and Ascard 1994; Kücke 1993). Carbon to nitrogen ratios of B. juncea, S. alba, and B. napus meals range from 7 to 10 (Morra and Johnson-Maynard 2003). Mineralizing the meal will thus provide a substantial amount of plant available $\mathrm{N}$ and no immobilization. Biofumigating compost with seed meal would thus add nitrogen to the mix and simultaneously reduce unwanted weed seeds and disease pathogens. 


\section{Crushing and Extraction Technology}

Current methods of cold pressing the meal result in residual oil of 5\%-10\% on a weight basis. Residual oil may help trap hydrophobic ITCs, prevent volatile losses, and increase pesticidal effectiveness. However, residual oil may also decrease the release efficiency of ITC from the meal into the soil and decrease its effectiveness. The overall impact of residual oil in the meal will vary with the ITC and its respective hydrophobicity. The effect of the oil on pest control has never been determined.

Commercial crushing facilities produce temperatures in the seed and seed meal that may deactivate myrosinase. Temperatures are increased on purpose to maximize oil extraction or unintentionally if an extrusion process follows crushing. The maximum temperature at which myrosinase integrity is maintained during a commercial crushing procedure has not been determined.

Current research is focused on using the meal as a carrier for the pesticide. The meal will also provide plant nutrients in addition producing ITC for pesticide control. However, the meal will also provide a carbon source for fungi and potentially increase pathogen problems. Extracting the ITC before soil application may circumvent this problem.

Techniques have been developed for extracting propenyl isothiocyanate from B. juncea meal using a commercially available unit. A commercial enterprise has been started by Mr. Peter Fergeson (Peter_I.M. Ferguson@eol.ieaust.org.au) in NSW Australia to extract propenyl ITC using a unit built by Flavourtech (33 Lenehan Rd., Griffith, NSW 2680, Australia). The ITC is then marketed to Japanese companies that use it as a food additive. Using a similar approach for producing pesticides seems feasible. 


\section{Allergenic Reactions}

Although the compounds are produced by plants, human and animal toxicity is still a concern if alternative pest control strategies are to be implemented. Do natural toxic substances in plants have advantages over synthetic pesticides? In contrast to a new synthetic pesticide, much information about the toxicology of these products is already known because of the importance of cruciferous crops in human nutrition and animal diets.

When used as a primary food source, glucosinolate-containing plant material clearly has deleterious effects. Feeding kale to livestock can reduce fertility and induce goiter (Johnston and Jones 1966). Diets of crambe meal caused early death to rats (Daxenbichler et al. 1966), and in separate tests, rats fed crambe meal and rapeseed meal exhibited symptoms similar to rats with nitriles in their rations (Van Etten and Tookey 1979). Livestock poisoning has been commonly reported when animals are fed excessive cruciferous plant material (Kingsbury 1964).

ITCs are general biocides whose activity results from interaction with proteins. They interact nonspecifically and irreversibly with proteins and amino acids to form stable products by reacting with sulfhydryl groups (Fenwick et al. 1983; Kawakishi and Kaneko 1985; Ware 1983), disulfide bonds (Kawakishi et al. 1983), and amines (Kawakishi and Kaneko 1987; Wood 1975). Reaction with terminal amino groups is the basis of the well-known Edman degradation for amino acid sequencing of proteins. ITCs inactivate enzymes in vitro, but the actual effects in vivo may be controlled by accessibility (Wood 1975).

Numerous studies concerning ITC toxicities have been performed. Contact of ITCs with skin and mucous membranes (respiratory tract) cause irritation, and many are considered lachrimators. At $20-50 \mathrm{mg} \mathrm{kg}^{-1}$ body weight propenyl ITC produced epithelial hyperplasia, stomach ulcers, and minor inflammatory foci in the livers of dogs, but did not show similar effects in rats even at $500 \mathrm{mg} \mathrm{kg}^{-1}$ body weight (Hall 1973). Antithyroid effects are attributed to ITCs, although this may be caused by metabolic conversion of the ITCs to $\mathrm{SCN}^{-}$ . An oral $\mathrm{LD}_{50}$ in rats for methyl ITC is listed as $175 \mathrm{mg} \mathrm{kg}^{-1}$ (Worthing 1987) and $339 \mathrm{mg}$ $\mathrm{kg}^{-1}$ for propenyl ITC (Wood 1975). Subcutaneous $\mathrm{LD}_{50}$ values are considerably lower at 50 $\mathrm{mg} \mathrm{kg}^{-1}$ for methyl ITC and $80 \mathrm{mg} \mathrm{kg}^{-1}$ for propenyl ITC (Wood 1975). The $\mathrm{LC}_{50}$ of methyl ITC at $96 \mathrm{~h}$ is $0.13 \mathrm{mg} \mathrm{L}^{-1}$ for bluegill and $0.37 \mathrm{mg} \mathrm{L}^{-1}$ for trout and carp (Worthing 1987).

Mammalian systems metabolize and eliminate ITCs fairly rapidly. Less than 5\% of a dose of propenyl ITC was retained by rats and mice $24 \mathrm{~h}$ after administration (Ioannou et al. 1984). ITCs administered both orally and by injection in rats and mice are primarily detoxified by glutathione and excreted as $S$-( $N$-methylthiocarbamoyl)mercapturic acids (Lam et al. 1993; Ioannou et al. 1984; Mennicke et al. 1983). Detoxification and excretion of benzyl ITC in humans is similar (Mennicke et al. 1988).

ITC attack of DNA and cancer cell induction seem to be unimportant in describing the mode of toxicity. Mutagenicity tests are sometimes positive, but often negative (Fenwick et al. 
1983; Ioannou et al. 1984; Musk and Johnson 1993). Chronic administration of propenyl ITC to rats and mice caused papillary growths in bladders of male rats only (related to more concentrated metabolite excretion), but did not cause tumors (Ioannou et al. 1984). There is in fact evidence that ITCs are anticarcinogenic (Mossoba et al. 1989; Fimognari et al. 2004). Glucosinolate-containing cruciferous vegetables such as cabbage, broccoli, and Brussels sprouts are correlated with reduced incidence of cancer (Graham et al. 1978). Tumors were inhibited in mice and rats that were given ITCs both before and after administering known carcinogens (Fenwick et al. 1983; Wattenberg 1977, 1981). Short-term chemical mechanisms appear to be involved in the suppression, such as high toxicity toward cancer cells (Nastruzzi et al. 1996), but longer term induction of enzyme systems that fight cancer in the body are also implicated (Institute of Food Technologists 1993). A potent inducer of protective enzymes is 4-methylsulfinylbutyl ITC found in broccoli (Zhang, et al. 1992, 1994). Thus, if ITC is consumed in normal dietary levels, it may be more beneficial than harmful.

Toxicological implications of glucosinolate hydrolysis must also include the possibility of OZT formation. The most common OZT, 5-vinyl-2-oxazolidinethione, is often referred to as "goitrin" because of its ability to induce goiter in the thyroid gland. High-protein rapeseed meal has limited use as a cattle feed, in part because the glucosinolate precursor of goitrin is present in large amounts. Other information on biological activity is relatively scarce, although OZTs interfere with a few enzymatic processes. For example, OZTs prevent the oxidation of trimethylamine (Fenwick et al. 1983) and goitrin moderately inhibits dopamine $\beta$-hydroxylase (Zenker et al. 1988). OZT toxicities to mice reported in the form of $\mathrm{LD}_{50}$ values range from 1260 to $1415 \mathrm{mg} \mathrm{kg}^{-1}$ (Van Etten and Tookey 1979). There is some susceptibility to nitrosation in the presence of nitrite (Lüthy et al. 1984), suggesting the possible formation of carcinogenic compounds under conditions encountered in the stomach. General toxicity appears to be relatively low, but further investigation of OZT toxicities seems appropriate.

Toxicity of other organic products, including nitriles, epithionitriles, and thiocyanates is likely related to the cyano group. Cyanide salts and gas inactivate certain enzyme systems, especially those involved in cellular respiration such as cytochrome oxidase (Johnston 1987; Sittig 1985). Similarities in the metabolism of organic nitriles and cyanide include increased urinary excretion of $\mathrm{SCN}^{-}$, detection of $\mathrm{CN}^{-}$in tissues, and depressed cytochrome oxidase activity (Duncan 1991). Toxicities of organic nitriles vary but are generally lower than cyanide salts and hydrogen cyanide. Toxicity seems particularly pronounced towards the liver (hepatotoxic) and kidney (Dietz et al. 1991; Duncan 1991; Fenwick et al. 1983; Van Etten et al. 1969). The $\mathrm{LD}_{50}$ in rats for ethyl CN (propanenitrile) is $50-100 \mathrm{mg} \mathrm{kg}^{-1}$ (Sittig 1985); for 1-cyano-2-hydroxy-3-butene, values of $170 \mathrm{mg} \mathrm{kg}^{-1}$ and $200 \mathrm{mg} \mathrm{kg}^{-1}$ have been reported (Fenwick et al. 1983; Tookey et al. 1980). Unsaturated nitriles appear to be less toxic than saturated nitriles. For example, rat oral $\mathrm{LD}_{50}$ 's exceeded $600 \mathrm{mg} \mathrm{kg}^{-1}$ for 3butenyl $\mathrm{CN}$ (4-pentenenitrile) and $720 \mathrm{mg} \mathrm{kg}^{-1}$ for benzonitrile, although acetonitrile (methyl $\mathrm{CN}$ ) is an exception with a reported oral $\mathrm{LD}_{50}$ in rats of $3030-6500 \mathrm{mg} \mathrm{kg}^{-1}$ (Dietz et al. 1991; Smiley 1979). 
Thiocyanate and epithionitrile toxicities appear similar to nitrile toxicities. Low molecular weight thiocyanates, including benzyl and phenyl, respond to the same antidotes for poisoning as does cyanide (Wood 1975). Alkyl thiocyanates are generally more active than aromatic thiocyanate, and toxicity decreases with increasing molecular weight (Wood 1975). For 1-cyano-3,4 epithiobutane, mortality in rats occurred after ingestion of $180 \mathrm{mg} \mathrm{kg}{ }^{-1}$ (Dietz et al. 1991) and an $\mathrm{LD}_{50}$ of $109 \mathrm{mg} \mathrm{kg}^{-1}$ has been reported (Fenwick et al. 1983). An $\mathrm{LD}_{50}$ range of 178-240 mg kg-1 was estimated for 1-cyano-2-hydroxy-3,4 epithiobutane (Van Etten et al. 1969).

Although the $\mathrm{LD}_{50}$ reported for 3-indolylacetonitrile in rats is $255 \mathrm{mg} \mathrm{kg}^{-1}$, indolyl products such as 3-indolylmethanol stimulate enzymatic systems involved in detoxification of xenobiotics and the inhibition of cancer (Loub et al. 1975). Protective activity, however, is less dramatic than with ITCs. Results of several experiments are somewhat mixed depending on the system examined and the specific conditions (McDanell et al. 1988), making it difficult to assess actual impact. In one study conducted with trout, 3-indolylmethanol administered after exposure to aflatoxin $\mathrm{B}_{1}$ actually enhanced carcinogenesis. However, 3indolylmethanol, as well as several ITCs, OZTs, and nitriles, were not teratogenic in rats (Fenwick at al. 1983).

$\mathrm{SCN}^{-}$is generally less toxic than either ITCs or organic cyano compounds. In fact, biological systems often metabolically detoxify cyanides by rhodanese-catalyzed conversion to $\mathrm{SCN}^{-}$, which is then readily excreted (exogenous sulfur is needed and thus thiosulfate is administered as part of the antidote for cyanide poisoning). Rhodanese is widely distributed in nature (Tabatabai and Singh 1976). As a result, $\mathrm{SCN}^{-}$was considered nontoxic and was used for a time as a drug to reduce blood pressure. However, side effects of $\mathrm{SCN}^{-}$caused its use to be dropped.

$\mathrm{SCN}^{-}$toxicity to rats is similar to benzonitrile with a reported $\mathrm{LD}_{50}$ for $\mathrm{NaSCN}$ of $765 \mathrm{mg}$ $\mathrm{kg}^{-1}$. Dogs are more susceptible than rats or mice to $\mathrm{SCN}^{-}$(Wood 1975). The process of cyanide conversion to $\mathrm{SCN}^{-}$is apparently in metabolic equilibrium, and adding $\mathrm{SCN}^{-}$to biological systems produces cyanide. However, this alone does not account for its acute toxicity (Wood 1975). $\mathrm{SCN}^{-}$interacts with proteins, and is listed as the most effective anion in the Hofmeister series for destabilizing protein structure (Voet and Voet 1990; Wood 1975). It may act as a noncompetitive inhibitor with many enzymes, and penetrates cell membranes (Wood 1975). $\mathrm{SCN}^{-}$is a pseudohalogen that acts as a competitor with iodine and thus may cause goiter. Unlike goiter caused by OZT, goiter resulting from $\mathrm{SCN}^{-}$can be corrected by adding iodine to the diet.

Effects of specific glucosinolate degradation products on individual organisms vary and are not always known. In sufficient quantity many of these compounds are highly toxic. Even with plant tissues, irritation of skin from excessive handling or a negative respiratory reaction might occur. However, exposure to amounts encountered in pest control strategies with plant tissues is likely to be minimal. The action of the toxins is direct and "up front." There do not appear to be serious, more subtle, negative long-term impacts on human health such as cancer or birth defects. Indeed, we have probably ingested many of these compounds in low levels for thousands of years, most of the time presumably without detriment. 


\section{Registration}

Products derived from mustard meal or meal-containing glucosinolates have been registered for a variety of purposes (Table 4). EPA has granted an "Exemption From the Requirement of Tolerance to Isothiocyanate as a Component of Food Grade Oil of Mustard" (Federal Register 1966). The most relevant products in the current discussion include mustard meal (B. juncea), currently marketed in Australia as a snail and slug killer and meadowfoam (Limnanthes alba) meal marketed in the United States as a soil amendment in horticulture. Meadowfoam meal is marketed by Natural Plant Products as Limnax ${ }^{\mathrm{TM}}$, AlbaGro ${ }^{\mathrm{TM}}$, and AlbaAide $^{\mathrm{TM}}$. EPA approved pesticides containing propenyl ITC as an active ingredient are marketed by Champon Natural Products (Champon Millenium Chemicals, Inc. 11112 Split Rail Lane, Fairfax Station, VA 22039; Phone: 703-426-8424; E-mail:

champon@ix.netcom.com; website: www.champon.com). A number of other products containing propenyl isothiocyanate as an active ingredient have been approved by the EPA for various pests (Table 4). Thus, the precedent for EPA approval of products containing propenyl ITC as an active ingredient has been set. Additional ITCs contained in other meals other than $B$. juncea most likely will require greater testing before it can be approved by the EPA. 


\section{Genetics and Interspecific Hybridization}

Canola or rapeseed (Brassica napus L.) is a member of the Brassicaceae family. Canola is the term used to describe Brassicaceae cultivars that contain erucic acid less than $2 \%$ of the total fatty acid content and less than $30 \mu \mathrm{mol}$ per gram of total glucosinolates in oil-free meal (Arnoldo et al. 1992). Rapeseed is used to describe oilseed $B$. napus with high (>40\%) erucic acid content in the oil. Traditionally rapeseed cultivars also contained high (80-120 $\mu \mathrm{mol}$ per gram of total glucosinolates in oil-free meal) glucosinolate content in the seed meal, although new rapeseed cultivars have seed meal comparable to canola.

Early records indicate that canola (rapeseed) was cultivated in India more than 3,000 years ago. It was later introduced to China and Japan (Shahidi 1990). The exact center of origin for $B$. napus is uncertain; however, it may have had multiple areas of origin in Europe within overlapping ranges of the diploid parental taxa (B. rapa and B. oleracea) (Warwick and Francis 1994). The main phytogeographical zones for B. napus are the Euro-Siberian, and the Irano-Turanian regions (Warwick and Francis 1994). The main regions of canola cultivation are parts of Asia (China, India, Indonesia), Europe, the Americas (mainly Canada), parts of Africa, and Australasia.

\section{A. Taxonomy, Genomic Constitutions, and Relationships}

The origins of amphidiploid B. napus, B. carinata, and B. juncea were suggested by $\mathrm{U}$ (1935), based on interspecific hybridizations and chromosome counts (Figure 3). This triangle arrangement of species indicates that cultivated canola, B. napus $(\mathrm{n}=19$, AACC genome), originated as a result of natural hybridization between $B$. oleracea $(\mathrm{n}=9, \mathrm{CC}$ genome) and B. rapa ( $\mathrm{n}=10$, AA genome) (U 1935; McNaughton 1976). This has been confirmed by later studies using different techniques, including flavonoid composition (Dass and Nybom 1967) and seed protein serology (Vaughan 1977). Song et al. (1988) used RFLPs to study the genomic constitution of diploid and amphidiploid species, and concluded that amphidiploid B. napus has evolved through different combinations of the diploid morphotypes (B. rapa and B. oleracea) and that phylogenetic origins may be common mechanisms for the natural occurrence of amphidiploids in Brassica, which confirmed that B. napus is an interspecific hybrid derived from B. rapa and B. oleracea. The authors suggested that the $\mathrm{C}$ genome component is larger in the cultivated $B$. napus lines, since these plants were closer to the $\mathrm{C}$ genome than the $\mathrm{A}$ genome in the phylogenetic tree.

\section{B. Oil and Seed Meal Characteristics and Inheritance}

The major fatty acids of Brassica species oil are palmitic (16:0), stearic (18:0), oleic (18:1), linoleic (18:2), linolenic (18:3), eicosenoic (20:1) and erucic acids (22:1). Some mustard species also have relatively high concentrations of nervonic acid (24:1). Canola oil must, by definition, not exceed more than $2 \%$ erucic acid content. In contrast, industrial rapeseed oil is usually very high (40\%-50\%) in erucic acid content. Laboratory animals that eat diets with a high proportion of oil containing high erucic acid levels perform poorly. Also, high erucic acid levels in human 
diets can cause abnormality of fat utilization in the heart and skeletal muscles, with undesirable changes in the tissue of the myocardium (Roine et al. 1960). Other reports from Canada and Europe have confirmed these changes and have shown that they do not occur with diets containing canola type oil with a low erucic acid content (Abdellatif et al. 1970). In canola, reduced erucic acid content is almost always associated with high oleic acid content, which is almost as effective in reducing cardiovascular risk as is the long-touted polyunsaturated linoleic acid (Ackman 1990).

Linolenic acid is very unstable and is easily oxidized to give unpleasant smelling substances. Canola oil contains 8\%-12\% linolenic acid, although cultivars can be developed with reduced levels (DeBonte 1994). In contrast, a high percentage of linoleic acid in edible oil is desirable (Scarisbrick and Daniels 1986). Canola oil is relatively low in this nutritionally valuable fatty acid, and an increase would improve its dietary value (Holmes 1980). Nutritionally, linoleic acid (vitamin F) is an important and essential polyunsaturated fatty acid that also reduces cholesterol content in the blood and is an essential component of cell membranes (Scarisbrick and Daniels 1986).

Yellow mustard ( $S$. alba) contains considerably higher erucic acid levels than are suitable as an edible oil. Also, yellow mustard does not produce high enough erucic acid levels to be valuable for industrial purposes (Carlson and Van Dyne 1992). In addition, yellow mustard is low in linoleic acid and has higher linolenic acid than would be desirable in edible oil.

Since the early 1960s, many researchers have investigated the inheritance of erucic acid content in several Brassica species. In B. napus, erucic and eicosenoic acid content are controlled by the genotype of the developing embryo and not by the sporophyte (Dorrel and Downey 1964; Harvey and Downey 1964; Kondra and Stefansson 1965; Stefansson and Hougen 1964). Erucic acid content in B. napus is controlled by a two gene-pair-system acting in an additive manner (Downey and Craig 1964; Kondra and Stefansson 1965; Stefansson and Hougen 1964). Jönsson (1977a, 1977b) found that erucic acid content in B. napus is controlled by a series of multiple alleles. Levels of 5\%-10\%, 20\%-35\%, and more than 35\% erucic acid content are controlled by alleles at one, one or two, and two loci, respectively.

Very few studies have been carried out to examine the inheritance of fatty acid profiles in S. alba (Rafiullah 1994). Rafiullah used a 4x4 half diallel cross to determine the inheritance of fatty acid profile as quantitative characteristics. The results indicated that erucic and oleic acids had greater additive genetic variation than dominant genetic variation, and that erucic acid was controlled by additive and nonadditive genes with some degree of linkage and or epistasis in $S$. alba. However, these studies were conducted by chemically analyzing field open pollinated seed. This could add serious bias to the results because of outcrossing. Tang et al. (1995) found that erucic acid content in yellow mustard has a large quantitative component with a few major dominant alleles.

Traditional rapeseed cultivars (where canola cultivars were derived) all had relatively high concentrations of glucosinolates in the seed that adversely affected the quality of the meal as livestock feed. When glucosinolate compounds are enzymatically degraded, they produce toxic compounds that can cause metabolic disturbances when fed to nonruminant livestock (Kondra 
and Stefansson 1970). High glucosinolate levels needed therefore to be reduced in rapeseed cultivars to avoid these detrimental effects on animals consuming the meal (Josefsson 1972).

A tremendous breeding effort was made to develop low-glucosinolate rapeseed (canola). The cultivar "Bronowsky" was the original, and only, source of low glucosinolates in B. napus and $B$. rapa. The genes that affect the early stages of biosynthesis of the major glucosinolates apparently control biosynthesis of glucosinolates in Bronowsky. This cultivar had low levels of glucosinolates in 1968 but was unadapted (Jönsson 1977a; Josefsson and Appelqvist 1968; Kondra and Downey 1969; Kondra and Stefansson 1970). However, the cultivars "Tower" and "Erglu" were developed relatively quickly by a backcross procedure to combine low levels of glucosinolates with low levels of erucic acid (Stefansson and Kondra 1975).

In contrast to canola, yellow mustard seed has traditionally been selected for condiment mustard powders. Mustard pungency is associated with high content of glucosinolates and their hydrolysis products (Holmes 1980). Therefore, past breeding efforts in this species have been aimed at increasing glucosinolate levels rather than making any attempt to reduce the content of glucosinolates in the seed.

Very few studies have examined the inheritance of glucosinolates in yellow mustard. This is mainly because very little genetic variation has been found for this trait within the species. Glucosinolate content of $S$. alba seeds produced from the same parent from both self- and crosspollinations were similar, showing that inheritance of glucosinolates is maternally controlled (Kondra and Stefansson 1970; Love et al. 1990). F $F_{2}$ seed of reciprocal crosses contained both 2propenyl and 3-butenyl glucosinolates, indicated nuclear genes controlled their formation. Love et al. (1990) also concluded that the synthesis of both 2-propenyl and 3-butenyl glucosinolates were controlled by multiple additive alleles at the same loci. More recently a single recessive allele has been identified (Brown et al. 2002) that completely blocked 3-hydroxybenzyl glucosinolate in yellow mustard seed meal.

\section{Interspecific and Intergeneric Crosses in Brassicaceae}

Substantial literature discusses intergeneric cross compatibility within the family Brassicacae. $B$. napus has been combined with several species of Diplotaxis and Eruca by sexual crosses and embryo rescue (Batra et al. 1990; Ringdahl et al. 1987), and with various other Brassica species (Glimelius et al. 1990; Jourdan et al. 1989a; Sjodin and Glimelius 1989). Other intergeneric Brassica hybrids produced include various combinations of B. juncea, B. campestris, Diplotaxis, Eruca, Raphanus, Moricandia, and Trachystoma (e.g. Agnihotri et al. 1990a, 1990b; Bing et al. 1996; Chevre et al. 1997; Kirti et al. 1992; Metz et al. 1997; Sikdar et al. 1990; Takahata and Takeda 1990; Toriyama et al. 1987a, 1987b). These hybrids generally showed some degree of fertility in crosses and have a range of chromosome numbers in their progeny.

Agnihotri et al. (1990a, 1990b) reported on the production of B. napus $\times$ Raphanobrassica and $B$. napus $\times$ Eruca using controlled crossing followed by embryo rescue. Lefol and Darmency (1993) studied spontaneous and manual interspecfic and intergeneric crosses between $B$. napus and two weedy relatives, $B$. adpressa and $R$. raphanistrum. They were 
able to obtain hybrids that showed superior vegetative development compared to the weed parent; the backcrosses to the parents also produced seed. In their studies on interspecific crosses, Nishiyama et al. (1991) found that many of these crosses produced wrinkled or empty seed because of poor endosperm development. However, crosses between B. napus and $B$. campestris and between $B$. napus and $B$. nigra spontaneously produced a few true $\mathrm{F}_{1}$ seeds (Nishiyama et al. 1991). Sucessful intergeneric hybridization between B. napus and $S$. alba have recently been reported (Brown et al. 1994, 1997). The result of this latter hybrid combination prompted further investigation of $B$. napus $\mathrm{x} S$. alba hybrids with elevated glucosinolate content for use as biofumigants.

Kerlan et al. (1992) studied the potential for interspecific hybrid production between $B$. napus and five related species (B. oleracea L. var capitate, B. oleracea L. var acephala, $B$. nigra L. Koch, B. adpressa L., R. raphanistrum L., and $S$. arvensis). Under optimal conditions with in vitro ovary culture, hybrid plants were obtained in all species cross combinations and more hybrids were obtained when canola was used as the female.

Eber et al. (1994) reported that spontaneous hybridization between male sterile B. napus and $B$. adpressa and $R$. raphanistrum where the pollen fertility of hybrids was $0 \%-30 \%$.

In a study involving six B. napus and four S. arvensis lines (Bing et al. 1995), no hybrids were obtained from any cross. When ovule culture was used, one hybrid from $B$. napus $\times S$. arvensis was obtained but was highly sterile. The authors concluded that the crossing between and transfer of genes from B. napus to $S$. arvensis would be remote even under favorable conditions. 


\section{Recommendations}

Meals with isothiocyanate-producing glucosinolate concentrations in excess of $200 \mu \mathrm{mol} \mathrm{g}$ tissue will most effectively control a wide variety of plant pests. The target is to produce in

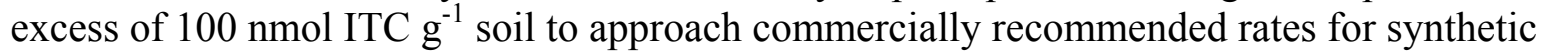
ITC pesticides. This should be possible assuming glucosinolate to ITC release efficiencies of $20 \%$. Consideration should be given to increasing the release efficiency of the ITC from the meal using physical methods of processing the meal or through the addition of adjuvants. Absolute ITC amounts and release efficiencies must be determined for the meals of interest to confirm that we indeed are producing ITC in excess of $100 \mathrm{nmol} \mathrm{g}^{-1}$ soil. Meals must be tested against specific target organisms and phytotoxic effects on the crop plant must be determined. Fungal pathogens will be the most difficult to control because carbon added to the soil in the form of meal may enhance growth of the pathogen. Insects, nematodes, and weeds will be more easily controlled, and commercialization of a final product with acceptable efficacy is likely. Different ITCs express different toxicities as a result of direct effects on the plant pest as well as differential sorption and reaction with soil colloids. Bioassay results obtained in the absence of soil must therefore be confirmed within the soil environment. Predictions of ITC pesticidal activity should be approached in the same fashion as commercial pesticides by determining organic carbon partition coefficients, Henry's constants, and half-lives. These parameters will vary with the ITC, and pesticidal activity can be optimized by selecting ITCs with the greatest potential for efficacy. The potential to introduce thiofunctionalized glucosinolates into species by way of breeding efforts may improve pesticidal efficacy of the meal. Additional benefits from the meal such as $\mathrm{N}$ release may increase the advantages of using meal amendments in cropping strategies. Effort should be devoted to quantifying the nutrient benefits of meal amendment since such benefits may be just as important to the consumer as pesticidal activity. 


\section{LITERATURE CITED}

Abdellatif, A.M.M. and Vles, R.O. Physical Effects of Rapeseed Oil and Canola Oil in Rats. In: Proc. International Conference on Rapeseed and Rapeseed Products, St. Adele, Canada. 1970, pp. 423-431.

Ackman, R.G. Canola Fatty Acid - An Ideal Mixture for Health, Nutrition and Food Use. In: Canola and Rapeseed Production, Chemistry, Nutrition and Processing. Shahidi, F (Eds). van Nostrand Reinhold, NY. 1990.

Agnihotri, A., Gupta, B., Lakshmikumaran, M.S., Shivanna, K.R., Prakash, S., and Jagannathan, V. Production of Eruca-Brassica Hybrids by Embryo Rescue. Plant Breeding 1990a, 104, 281-289.

Agnihotri, A., Shivanna, K.R., Raina, S.N., Lakshimikumaran, M., Prakash, S., and Jagannathan, V. Production of Brassica napus $\times$ Raphanobrassica Hybrids by Embryo Rescue: An Attempt to Introduce Shattering Resistance into B. napus. Plant Breeding 1990b, 104, 292-299.

Åhman, I. Toxicities of Host Secondary Compounds to Eggs of the Brassica Specialist Dasineura brassicae. J. Chem Ecol. 1986, 12, 1481-1488.

Al-Shehbaz, I.A. and Al-Shammary, K.I. Distribution and Chemotaxonomic Significance of Glucosinolates in Certain Middle-Eastern Cruciferae. Biochem. Systemat. Ecol. 1987, 15, 559-569.

Alvarez, R.A. and Moore, C.B. Quantum Yield for Production of $\mathrm{CH}_{3} \mathrm{NC}$ in the Photolysis of $\mathrm{CH}_{3} \mathrm{NCS}$. Science 1994, 263, 205-207.

Andersen, A.S. and Muir, R.M. Auxin Activity of Glucobrassicin. Phys. Plantarum 1966, 19, 1038-1048.

Angus, J.F., Gardner, P.A., Kirkegaard, J.A., and Desmarchelier, J.M. Biofumigation: Isothiocyanates Released from Brassica Roots Inhibit Growth of the Take-All Fungus. Plant and Soil 1994, 162, 107-112.

Arnoldo, M., Baszcynski, C.L. Bellemare, G., Brown, G., Carlson, J., Gillespie, B., Huang, B., MacLean, N., MacRae, W.D., Rayner, G., Rozakis, S., Westecott, M., and Kemble, J.G. Evaluation of Transgenic Canola Plants under Field Conditions. Genome 1992, 35, 58-63.

Ascard, J. and Jonasson, T. White Mustard Meal Interesting for Weed Control. In Weeds and Weed Control. Reports. 32nd Swedish Crop Protection Conference. Swedish University of Agricultural Sciences: Uppsala 1991; pp. 139-155.

Ashley, M.G., Leigh, B.L., and Lloyd, L.S. The Action of Metham-Sodium in Soil. J. Sci. Food Agric. 1963, 14, 153-161. 
Bailey, S.D., Bazinet, M.L., Driscoll, J.L., and McCarthy, A.I. The Volatile Components of Cabbage. J. Food Sci. 1961, 26, 163-170.

Bartlet, E., Parsons, D., Williams, I.H., and Clark, S.J. The Influence of Glucosinolates and Sugars on Feeding by the Cabbage Stem Flea Beetle, Psyliodes chrysocephala. Ent. Exp. Appl. 1994, 73, 77-83.

Batra V, Prakash, S., and Shivanna, K.R. Intergeneric Hybridization between Diplotaxis siifolia, a Wild Species and Crop Brassicas. Theor. Appl. Genet. 1990, 80, 537-541.

Bäuerle, R., Wagner, H., and Schraudolf, H. Distribution of 4-methoxy-3-indolylmethylglucosinolate (4-methoxy-glucobrassicin) in Brassicaceae. Experientia 1986, 42, 86.

Beekhuis, H.A. Technology and Industrial Applications. In Chemistry and Biochemistry of Thiocyanic Acid and Its Derivatives. Newman, A.A., Ed.; Academic Press: London 1975; pp. 222-255.

Bell, D.T. and Muller, C.H. Dominance of California Annual Grasslands by Brassica nigra. Amer. Midl. Nat. 1973 90, 277-299.

Bending, G.D., and Lincoln, S.D. Characterisation of Volatile Sulphur-Containing Compounds Produced during Decomposition of Brassica juncea Tissues in Soil. Soil Biol. Biochem. 1999, 31, 695-703.

Betts, P.M., Rinder, D.F., and Fleeker, J.R. Thiocyanate Utilization by an Arthrobacter. Can. J. Microbiol. 1979, 25, 1277-1282.

Bhardwaj, H.L., Hamama, A.A., Porter, D.M., and Resse, P.F., Jr. Rapeseed Meal as a Natural Pesticide. In Progress in New Crops. ASHS Press, Arlington, VA, J. Janick, Ed., pp. 615-619.

Bialy, Z., Oleszek, W., Lewis, J., and Fenwick, G.R. Allelopathic Potential of Glucosinolates (Mustard Oil Glycosides) and Their Degradation Products against Wheat. Plant and Soil 1990, 129, 277-281.

Bing, D.J., Downey, R.K., and Rakow, G.F.W. An Evaluation of the Potential of Intergeneric Gene Transfer between Brassica napus and Sinapis arvensis. Plant Breeding 1995, 114, 481484.

Bing D.J., Downey, R.K., and Rakow, G.F.W. Assessment of Transgenic Escape from Brassica rapa (B. campestris) into B. nigra or Sinapis arvensis. Plant Breeding 1996, 115, 1-4.

Birch, A.N.E. Field and Glasshouse Studies on Components of Resistance to Root Fly Attack in Swedes. Ann. Appl. Biol. 1988, 113, 89-100. 
Birch, A.N.E., Griffiths, D.W., Hopkins, R.J., Macfarlane-Smith, W.H., and McKinlay, R.G. Glucosinolate Responses of Swede, Kale, Forage and Oilseed Rape to Root Damage by Turnip Root Fly (Delia floralis) Larvae. J. Sci. Food Agric. 1992, 60, 1-9.

Björkman, R. Interaction between Proteins and Glucosinolate Isothiocyanates and Oxazolidinethiones from Brassica napus Seed. Phytochemistry 1973, 12, 1585-1590.

Björkman, R. Properties and Function of Plant Myrosinases. In The Biology and Chemistry of the Cruciferae. Vaughan, J.G., MacLeod, A.J., and Jones, B.M.G. Ed.; Academic Press: London 1976, pp. 191-205.

Blau, P.A., Feeny, P., and Contardo, L. Allylglucosinolate and Herbivorous Caterpillars: A Contrast in Toxicity and Tolerance. Science 1978, 200, 1296-1298.

Bodnaryk, R.P. Effects of Wounding on Glucosinolates in the Cotyledons of Oilseed Rape and Mustard. Phytochemistry 1992, 31, 2671-2677.

Bodnaryk, R.P. and Palaniswamy, P. Glucosinolate Levels in Cotyledons of Mustard, Brassica juncea L. and Rape, B. napus L. Do Not Determine Feeding Rates of Flea Beetle, Phyllotreta cruciferae (Goeze). J. Chem. Ecol. 1990, 16, 2735-2746.

Bones, A., and Slupphaug, G. Purification, Characterization and Partial Amino Acid Sequencing of $\beta$-thioglucosidase from Brassica napus. J. Plant Physiol. 1989, 134, 722-729.

Bones, A.M. Distribution of $\beta$-thioglucosidase Activity in Intact plants, Cell and Tissue Cultures and Regenerant Plants of Brassica napus. J. Exp. Bot. 1990, 41, 737-744.

Borek, V., Morra, M.J., Brown, P.D., and McCaffrey, J.P. Allelochemicals Produced during Sinigrin Decomposition in Soil. J. Agric. Food Chem. 1994, 42, 1030-1034.

Borek, V., Morra, M.J., Brown, P.D., and McCaffrey, J.P. Transformation of the Glucosinolate-Derived Allelochemicals Allyl Isothiocyanate and Allyl Nitrile in Soil. $J$. Agric. Food Chem. 1995a, 43, 1935-1940.

Borek, V., Elberson, L.R., McCaffrey, J.P., and Morra, M.J. Toxicity of Aliphatic and Aromatic Isothiocyanates to Eggs of the Black Vine Weevil (Coleoptera: Curculionidae). J. Econ. Entomol. 1995b, 88, 1192-1196.

Borek, V., and Morra, M.J. Unpublished data, 2003. Soil \& Land Resources Division, University of Idaho, Moscow ID 83844.

Borek, V., Morra, M.J., and McCaffrey, J.P. Myrosinase Activity in Soil Extracts. Soil Sci. Soc. Am. J. 1996a, 60, 1792-1797. 
Borek, V., Elberson, L.R., McCaffrey, J.P., and Morra, M.J. Toxicity of Isothiocyanates Produced by Glucosinolates in Brassicaceae Species to Black Vine Weevil Eggs. J. Econ. Entomol. 1998, 46, 5318-5323.

Boydston, R.A. and Hang, A. Rapeseed (Brassica napus) Green Manure Crop Suppresses Weeds in Potato (Solanum tuberosum). Weed Technol. 1995, 9, 669-675.

Brown, A.P., Brown, J., Thill, D.C., Brammer, T.A., and Nair, H.S. Gene Transfer between Canola (Brassica napus and Brassica campestris) and Related Weed Species. In Rapeseed Today and Tommorrow. 9th International Rapeseed Congress. Cambridge, UK 4-7 July 1995, pp. 1445-1447.

Brown, A.P., Brown, J., Davis, J.B., and Erickson, D.A. Intergeneric Hybridization between Yellow Mustard and Related Canola Species. American Society of Agronomy $86^{\text {th }}$ Annual Meeting. Seattle, WA, November 13-18, 1994.

Brown, J., Brown, A.P., Davis, J.B., and Erickson, D.A. Intergeneric Hybridization between Brassica napus L. and Sinapis alba L. Euphytica. 1997, 93, 163-168.

Brown, P.D. and Morra, M.J. Ion Chromatographic Determination of $\mathrm{SCN}^{-}$in Soils. J. Agric. Food Chem. 1991, 39, 1226-1228.

Brown, P.D. and Morra, M.J. Fate of Ionic Thiocyanate ( $\left.\mathrm{SCN}^{-}\right)$in Soil. J. Agric. Food Chem. 1993, 41, 978-982.

Brown, P.D. and Morra, M.J. Glucosinolate-Containing Plant Tissues as Bioherbicides. $J$. Agric. Food Chem. 1995, 43, 3070-3074.

Brown, P.D. and Morra, M.J. Hydrolysis Products of Glucosinolates in Brassica napus Tissues as Inhibitors of Seed Germination. Plant and Soil 1996, 181, 307-316.

Brown, P.D. and Morra, M.J. Control of Soil-Borne Plant Pests Using GlucosinolateContaining Plants. Adv. Agron. 1997, 61, 167-231.

Brown, P.D., Morra, M.J., and Borek, V. Gas Chromatography of Allelochemicals Produced during Glucosinolate Degradation in Soil. J. Agric. Food Chem. 1994, 42, 2029-2034.

Brown, P.D., Morra, M.J., McCaffrey, J.P., Auld, D.L., and Williams, L. III. Allelochemicals Produced during Glucosinolate Degradation in Soil. J. Chem. Ecol. 1991, 17, 2021-2034.

Campbell, A.G. A Germination Inhibitor and Root-Growth Retarder in Chou Moellier (Brassica oleracea var.). Nature 1959, 183, 1263-1264.

Carlson, D.G., Daxenbichler, M.E., Tookey, H.L., Kwolek, W.F., Hill, C.B., and Williams, P.H. Glucosinolates in Turnip Tops and Roots: Cultivars Grown for Greens and/or Roots. J. Amer. Soc. Hort. Sci. 1987, 112(1), 179-183. 
Carlson, K.D. and Van Dyne, D.L. Industrial Uses for High Erucic Acid Oils from Crambe and Rapeseed. 1992, Printed at the University of Missouri, October 1992.

Chae, Y.M. and Tabatabai, M.A. Colorimetric Determination of Allyl Isothiocyanate. Analyt. Lett. 1983, 16, 1197-1206.

Challenger, F. The Natural Mustard Oil Glucosides and the Related Isothiocyanates and Nitriles. In Aspects of the Organic Chemistry of Sulphur. Academic Press: New York, 1959, pp. 115-161.

Chan, M.K.Y. and Close, R.C. Aphanomyces Root Rot of Peas 3. Control by the Use of Cruciferous Amendments. N.Z.J. Agric. Res. 1987, 30, 225-233.

Chevre A-M., Eber, F. Baranger, A., and Renard, B. Gene Flow from Transgenic Crops. Nature 1997, 389, 924.

Chew, F.S. Biological Effects of Glucosinolates. In Biologically Active Natural Products: Potential Use in Agriculture;. Cutler, H.G., Ed. American Chemical Society: Washington, D.C. $1988 \mathrm{a}$, pp. 155-181.

Chew, F.S. Searching for Defensive Chemistry in the Cruciferrae, or, Do Glucosinolates Always Control Interactions of Cruciferae with Their Potential Herbivores and Symbionts? No! In Chemical Mediation of Coevolution. Spencer, K.C. Ed., American Institute of Biological Sciences, 1988b, pp. 81-112.

Chiang, M.S., Chong, C., Chevrier, G., and Crete, R. Glucosinolates in Clubroot-Resistant and -Susceptible Selections of Broccoli. HortScience 1989, 24, 665-666.

Chin, H.W. and Lindsay, R.C. Volatile Sulfur Compounds Formed in Disrupted Tissues of Different Cabbage Cultivars. J. Food Sci. 1993, 58, 835-841.

Chin, H.W. and Lindsay, R.C. Mechanisms of Formation of Volatile Sulfur Compounds Following the Action of Cysteine Sulfoxide Lyases. J. Agric Food Chem. 1994, 42, 15291536.

Chisholm, H. Biosynthesis of 3-Methoxycarbonylpropyl-Glucosinolate in an Erysimum Species. Phytochemistry 1973, 12, 605-608.

Choesin, D.V. and Boerner, R.E.J. Allyl Isothiocyanate Release and the Allelopathic Potential of Brassica napus (Brassicaceae). Amer. J. Bot. 1991, 78, 1083-1090.

Chong, C., and Bible, B. Variation in Thiocyanate Content of Radish Plants during Ontogeny. J. Amer. Soc. Hort. Sci. 1974, 99(2), 159-162. 
Chong, C., Chiang, M.S., and Crete, R. Thiocyanate Ion Content in Relation to Clubroot Disease Severity in Cabbages. HortScience 1981, 16, 663-664.

Clossais-Besnard, N. and Larher, F. Physiological Role of Glucosinolates in Brassica napus. Concentration and Distribution Pattern of Glucosinolates among Plant Organs during a Complete Life Cycle. J. Sci. Food Agric. 1991, 56, 25-38.

Cole, R. A. Isothiocyanates, Nitriles and Thiocyanates as Products of Autolysis of Glucosinolates in Cruciferae. Phytochemistry. 1976, 15, 759-762.

Cole, R.A. Volatile Components Produced during Ontogeny of Some Cultivated Crucifers. $J$. Sci. Food Agric. 1980, 31, 549-557.

Dale, J.E. Decline in Phytotoxicity of Benzyl Isothiocyanate Formulated as Granules. Weed Sci. 1986, 34, 325-327.

Dandurand, L.-M., Mosher, R.D., and Knudsen, G.R. Combined Effects of Brassica napus seed meal and Trichoderma harzianum on Two Soilborne Plant Pathogens. Can. J.

Microbiol. 2000, 46, 1051-1057.

Dass, H. and Nybom, H. The Relationships between Brassica nigra, B. campestris, $B$. oleracea, and Their Amphidiploid Hybrids Studied by Means of Numerical Chemotaxonomy. Can. J. Genet. Cytol. 1967, 9, 880-890.

Dateo, G.P., Clapp, R.C., MacKay, D.A.M., Hewitt, E.J., and Hasselstrom, T. Identification of the Volatile Sulfur Components of Cooked Cabbage and the Nature of the Precursors in the Fresh Vegetable. Food Res. 1957, 22, 440-447.

Daun, J.K. Glucosinolate Analysis in Rapeseed and Canola - an Update. J. Jpn. Oil Chem. Soc. (Yakagaku) 1986, 35, 426-434.

Davis, D. Host Fungitoxicants in Selective Pathogenicity of Fusarium oxysporum. Phytopathology 1964, 54, 290-293.

Davis, J.B. Winter Rapeseed (Brassica napus L.) with Differential Levels of Glucosinolate Evaluated as a Green Mnaure Crop to Suppress Aphanomyces Root Rot of Peas (Pisumpisum sativum L.). Master's Thesis 1988: University of Idaho.

Dawson, G.W., Doughty, K.J., Hick, A.J., Pickett, J.A., Pye, B.J., Smart, L.E., and Wadhams, L.J. Chemical Precursors for Studying the Effects of Glucosinolate Catabolites on Diseases and Pests of Oilseed Rape (Brassica napus) or Related Plants. Pestic. Sci. 1993, 39, 271-278.

Daxenbichler, M.E., Spencer, G.F., Carlson, D.G., Rose, G.B., Brinker, A.M., and Powell, R.G. Glucosinolate Composition of Seeds from 297 Species of Wild Plants. Phytochemistry 1991, 30, 2623-2638. 
Daxenbichler, M.E., Van Etten, C.H., and Wolff, I.A. (S)- and (R)-1-Cyano-2-Hydroxy-3Butene from Myrosinase Hydrolysis of Epi-Progoitrin and Progoitrin. Biochemistry 1966, 5, 692-697.

DeBonte, L. Commercial Production of Low Polyunsaturated Canola Oils. 1994. In Proceedings of the Pacific Northwest Canola Conference, November 9-11, Spokane, Washington, 1994. pp. 57-59.

Delaveau, P.G. and Kjaer, A. The Mustard Oils of Dentaria pinnata Lmk. Acta Chem. Scand. 1963, 17, 2562-2563.

del Rosario, A., Remoy, J., Soliman, V., Dhaliwal, J., Dhoot, J., and Perera, K. Monitoring for Selected Degradation Products Following a Spill of Vapam into the Sacramento River. $J$. Environ. Qual. 1994, 23, 279-286.

Dietz, H.M., Panigrahi, S., and Harris, R.V. Toxicity of Hydrolysis Products from 3-Butenyl Glucosinolate in Rats. J. Agric. Food Chem. 1991, 39, 311-315.

Dorrel, D.C. and Downey, R.K. The Inheritance of Erucic Acid Content in Rapeseed (Brassica campestris). Can. J. Plant Sci. 1964, 44, 499-504.

Doughty, K.J., Kiddle, G.A., Pye, B.J., Wallsgrove, R.M., and Pickett, J.A. Selective Induction of Glucosinolates in Oilseed Rape Leaves by Methyl Jasmonate. Phytochemistry 1995, 38, 347-350.

Doughty, K.J., Porter, A.J.R., Morton, A.M., Kiddle, G., Bock, C.H., and Wallsgrove, R. Variation in the Glucosinolate Content of Oilseed Rape (Brassica napus L.) Leaves. II. Response to Infection by Alternaria brassicae (Berk.) Sacc. Ann. Appl. Biol. 1991, 118, 469477.

Downey, R.K. and Craig, B.M. Genetic Control of Fatty Acid Biosynthesis in Rapeseed (Brassica napus L.). JAOCS 1964, 41, 475-478.

Drobnica, L., Zemanová, M., Nemec, P., Antoš, K., Kristián, P., Štullerová, A., Knoppová, V., and Nemec, P. Jr. Antifungal Activity of Isothiocyanates and Related Compounds. I. Naturally Occurring Isothiocyanates and Their Analogues. Appl. Microbiol. 1967a, 15, 701-709.

Drobnica, L., Zemanová, M., Nemec, P., Kristián, P., Antoš, K., and Hulka, A. Antifungal Activity of Isothiocyanates and Related Compounds. II. Mononuclear Aromatic Isothiocyanates. Appl. Microbiol. 1967b, 15, 710-717.

Duncan, A.J. Glucoinolates. In Toxic Substances in Crop Plants. D’Mello, J.P.F., Duffus, C.M., and Duffus, J.H. Ed.; The Royal Society of Chemistry: Cambridge 1991, pp. 126-147. 
Durham, P.L. and Poulton, J.E. Enzymic Properties of Purified Myrosinase from Lepedium sativum Seedlings. Z. Naturforsch. 1990. 45c, 173-178.

Dustman, R.B. and Duncan, I.J. Effect of Certain Thiocyanate Sprays on Foliage and Fruit in Apples. Plant Physiol. 1940, 15, 343-349.

Eagles, J., Fenwick, G.R., Gmelin, R., and Rakow, D. The Chemical Ionization Mass Spectra of Glucosinolates (Mustard Oil Glycosides) and Desulphoglucosinolates. A Useful Aid for Structural Analysis. Biomed. Mass Spec. 1981, 8, 265-269.

Eber, F. Chèvre, A.M. Baranger, A., Vallée, P., Tanguy, X., and Renard, M. Spontaneous Hybridization between a Male-Sterile Oilseed Rape and Two Weeds. Theor. Appl. Genet. 1994, $88,2-368$.

Eide, P.M. Soil Fumigation to Control Weevil Grubs in Strawberries. J. Econ. Entom. 1959, 52, 3-5.

Elberson, L.R., Borek, V., McCaffrey, J.P., and Morra, M.J. Toxicity of Rapeseed MealAmended Soil to Limonius californicus (Mann.) (Coleoptera: Elateridae) wireworms. $J$. Agric. Entomol. 1996, 13, 323-330.

Elfakir, C., Lafosse, M., Viaud, M.C., and Dreux, M. New Artificial Standards for the HPLC Analysis of Natural Glucosinolates. J. High Res. Chromatog. 1992, 15, 392-398.

Elliott, M.C. and Stowe, B.B. A Novel Sulphonated Natural Indole. Phytochemistry 1970, 9, 1629-1632.

Elliott, M.C. and Stowe, B.B. Distribution and Variation of Indole Glucosinolates in Woad (Isatis tinctoria L.). Plant Physiol. 1971, 48, 498-503.

Erickson, J.M. and Feeny, P. Sinigrin: A Chemical Barrier to the Black Swallowtail Butterfly, Papilio polyxenes. Ecology 1974, 55, 103-111.

Ettlinger, M.G. and Kjaer, A. Sulfur Compounds in Plants. In Recent Advances in Phytochemistry Volume 1. Mabry, T.J., Ed.; Appleton-Century-Crofts: New York 1968, pp. 59-144.

Ettlinger, M.G. and Lundeen, A.J. The Structures of Sinigrin and Sinalbin: An Enzymatic Rearrangement. J. Am. Chem. Soc. 1956, 78, 4172-4173.

Fahey, J.W., Zalcmann, A.T., and Talalay, P. The Chemical Diversity and Distribution of Glucosinolates and Isothiocyanates among Plants. Phytochemistry 2001, 56, 5-51.

Fales, S.L., Gustine, D.L., Bosworth, S.C., and Hoover, R.J. Concentrations of Glucosinolates and $S$-Methylcysteine Sulfoxide in Ensiled Rape (Brassica napus L.) J. Dairy Sci. 1987, $70,2402-2405$. 
Falk, A., Xue, J., Lenman, M., and Rask, L. Sequence of a cDNA Clone Encoding the Enzyme Myrosinase and Expression of Myrosinase in Different Tissues of Brassica napus. Plant Sci. 1992, 83, 181-186.

Falk, A., Ek, B., and Rask, L. Characterization of a New Myrosinase in Brassica napus. Plant Mol. Biol. 1995a. 27, 863-874.

Falk, A., Taipalensuu, J., Ek, B., Lenman, M., and Rask, L. Characterization of Rapeseed Myrosinase-Binding Protein. Planta 1995b, 195, 387-395.

Federal Register, May 20 1966, Vol. 61, Number 98.

Fenwick, G.R., Heaney, R.K., and Mullin, W.J. Glucosinolates and Their Breakdown Products in Food and Food Plants. Crit. Rev. Food Sci. Nutr. 1983, 18, 123-201.

Fimognari, C., Nüsse, M., Iori, R., Cantelli-Forti, G., and Hrelia, P. The New Isothiocyanate 4-(methylthio)butylisothiocyanate selectively affects cell-cycle progression and apoptosis of human leukemia cells. Invest. New Drugs 2004, 22, 119-129.

Finch, S. and Skinner, G. Trapping Cabbage Root Flies in Traps Baited with Plant Extracts and with Natural and Synthetic Isothiocyanates. Ent. Exp. Appl. 1982, 31, 133-139.

Freeman, G.G. and Mossadeghi, N. Studies on Relationship between Water Regime and Flavour Strength in Watercress (Rorippa nasturtium-aquaticum (L) Hayek), Cabbage (Brassica oleracea capitata) and Onion (Allium cepa). J. Hort. Sci. 1973, 48, 365-378.

Freer, J.B.S., Ogilvy, S.E., Evans, E.J., Bilsborrow, P.E., Rawlinson, C.J., Milford, G.F.J., and Fieldsend, J.K. The Effects of Time and Method of Harvest on Seed Yield and Glucosinolate Concentration of Winter Oilseed Rape. Aspects Appl. Biol. 1989, 23, 145-150.

Frick, A., Zebarth, B.J., and Szeto, S.Y. Leaching and Volatilization of the Soil Fumigant Methylisothiocyanate: Influence of Soil Water Regime. In Proceedings of the Pacific Division, American Association for the Advancement of Science; 76th Annual Meeting, Program with Abstracts. Pacific Division, AAAS Publications: San Francisco 1995, p. 35.

Gaind, K.N., Gandhi, K.S., Juneja, T.R., Kjaer, A., and Nielsen B.J. 4,5,6,7-Tetrahydroxydecyl Isothiocyanate Derived from a Glucosinolate in Capparis grandis. Phytochemistry 1975, 14, 1415-1418.

Gamliel, A. and Stapleton, J.J. Characterization of Antifungal Volatile Compounds Evolved from Solarized Soil Amended with Cabbage Residues. Phytopathology 1993, 83, 899-905.

Gardiner, J.B., Morra, M.J., Eberlein, C., Brown, P.D, and Borek, V. Allelochemicals Released in Soil Following Incorporation of Rapeseed (Brassica napus) Green Manures. $J$. Agric. Food Chem. 1999, 47, 3837-3842. 
Geddes, J.D., Miller, G.C., and Taylor, G.E. Gas Phase Photolysis of Methyl Isothiocyanate. Environ. Sci. Technol. 1995, 29, 2590-2594.

Gil, V. and MacLeod, A.J. The Effects of $\mathrm{pH}$ on Glucosinolate Degradation by a Thioglucoside Glucohydrolase Preparation. Phytochemistry 1980, 19, 2547-2551.

Gilbert, J. and Nursten, H. E. Volatile Constituents of Horseradish Roots. J. Sci. Food Agric. 1972, 23, 537-539.

Glen, D.M., Jones, H., and Fieldsend, J.K. Damage to Oilseed Rape Seedlings by the Field Slug Deroceras reticulatum in Relation to Glucosinolate Concentration. Ann. Appl. Biol. 1990, 117 197-207.

Glenn, M.G., Chew, F.S., and Williams, P.H. Hyphal Penetration of Brassica (Cruciferae) Roots by a Vesicular-Arbuscular Mycorrhizal Fungus. New Phytol. 1985, 99, 463-472.

Glenn, M.G., Chew, F.S., and Williams, P.H. Influence of Glucosinolate Content of Brassica (Cruciferae) Roots on Growth of Vesicular-Arbuscular Mycorrhizal Fungi. New Phytol. 1988, 110, 217-225.

Glimelius K., Fahleson, J. Landren, M. Sjodin, C., and Sundberg, E. Improvements of the Brassica Crops by Transfer of Genes from Alien Species via Somatic Hybridization. In Progress in Plant Cellular and Molecular Biology (Nijkamp HJJ, Van Der Plas, L.H.W. and Van Aartrijk, J., Eds.). Kluwer Acad Press. 1990, pp. 299-304.

Gosden, A.F. An Automated Procedure for the Estimation of $S$-Methylcysteine Sulphoxide in Kale. J. Sci. Food Agric. 1979, 30, 892-898.

Graham, S., Dayal, H., Swanson, M., Mittelman, A., and Wilkinson, G. Diet in the Epidemiology of Cancer of the Colon and Rectum. J. Natl. Cancer Inst. 1978, 61, 709-714.

Greenhalgh, J.R. and Mitchell, N.D. The involvement of Flavour Volatiles in the Resistance to Downy Mildew of Wild and Cultivated Forms of Brassica oleracea. New Phytol. 1976, 77, 391-398.

Gressel, J.B. and Holm, L.G. Chemical Inhibition of Crop Germination by Weed Seeds and the Nature of Inhibition by Abutilon theophrasti. Weed Res. 1964, 4, 44-53.

Griffiths, D.C., Hick, A.J., Pye, B.J., and Smart, L.E. The Effects on Insect Pests of Applying Isothiocyanate Precursors to Oilseed Rape. Asp. Appl. Biol. 1989, 23, 359-364.

Griffiths, D.W., Bradshaw, J.E., Taylor, J., and Gemmell, D.J. Effect of Cultivar and Harvest Date on the Glucosinolate and S-Methylcysteine Sulphoxide Content of Swedes (Brassica napus ssp rapifera). J. Sci. Food Agric. 1991, 56, 539-549. 
Grinsted, M.J., Hedley, M.J., White, R.E., and Nye, P.H. Plant-Induced Changes in the Rhizosphere of Rape (Brassica napus var. Emerald) Seedlings. I. pH Change and the Increase in P Concentration in the Soil Solution. New Phytol. 1982, 91, 19-29.

Grob, K. Jr., and Matile P. H. Vacoular Location of Glucosinolates in Horseradish Root Cells. Plant Sci. Lett. 1979, 14, 327-335.

Grob, K. Jr. and Matile P. Capillary GC of Glucosinolate-Derived Horseradish Constituents. Phytochemistry 1980, 19, 1789-1793.

Grümmer, G. and Beyer, H. The Influence Exerted by Species of Camelina on Flax by Means of Toxic Substances. In The Biology of Weeds. Harper, J.L., Ed.; Blackwell Scientific Publications: Oxford 1960, pp. 153-157.

Hall, R.L. Toxicants Occurring Naturally in Spices and Flavors. In Toxicants Occurring Naturally in Foods. National Academy of Sciences: Washington, D.C. 1973; pp. 449-476.

Hammond, K.E. and Lewis, B.G. Variation in Stem Infections Caused by Aggressive and Non-Aggressive Isolates of Leptosphaeria maculans on Brassica napus Var. Oliefera. Plant Path. 1987, 36, 53-65.

Hanley, A.B., Heaney, R.K., and Fenwick, G.R. Improved Isolation of Glucobrassicin and Other Glucosinolates. J. Sci. Food Agric. 1983, 34, 869-873.

Hansen, M., Buttery, R.G., Stern, D.J., Cantwell, M.I., and Ling, L.C. Broccoli Storage under Low-Oxygen Atmosphere: Identification of Higher Boiling Volatiles. J. Agric. Food Chem. 1992, 40, 850-852.

Hansen, M., Møller, P., Sørensen, H., and de Trejo, M.C. Glucosinolates in Broccoli Stored under Controlled Atmosphere. J. Am. Soc. Hort. Sci. 1995, 120, 1069-1074.

Happold, F.C., Jones, G.L., and Pratt, D.B. Utilization of Thiocyanate by Thiobacillus thioparus and T. thiocyanoxidans. Nature 1958, 182, 266-267.

Harper, S.H.T. and Lynch, J.M. The Role of Water-Soluble Components in Phytotoxicity from Decomposing Straw. Plant and Soil 1982, 65, 11-17.

Harvey, B.L. and Downey, R.K. The Inheritance of Erucic Acid Content in Rapeseed (Brassica napus). Can. J. Pl. Sci. 1964, 44, 104-111.

Hasapis, X. and MacLeod, A.J. Effects of Metal Ions on Benzylglucosinolate Degradation in Lepidium sativum Seed Autolysates. Phytochemistry 1982, 21, 559-563.

Hedley, M.J., Nye, P.H., and White, R.E. Plant-Induced Changes in the Rhizosphere of Rape (Brassica napus var. Emerald) Seedlings. II. Origins of the pH Change. New Phytol. 1982a, 91, 31-44. 
Hedley, M.J., White, R.E., and Nye, P.H. Plant-induced Changes in the Rhizosphere of Rape (Brassica napus var. Emerald) Seedlings. III. Changes in $L$ Value, Soil Phosphate Fractions and Phosphatase Activity. New Phytol. 1982b, 91, 45-56.

Heijbroek, W. The Influence of Resistant Cruciferous Green Manure Corps on Beet Cyst Nematodes. Mededeling Nr. 8. Instituut voor Rationele Suikerproductie: Nederland 1982.

Hill, C.B., Williams, P.H., Carlson, D.G., and Tookey, H.L. Variation in Glucosinolates in Oriental Brassica Vegetables. J. Amer. Soc. Hort. Sci. 1987, 112(2), 309-313.

Hogendoorn, E.A., Verschraagen, C., Brinkman, U.A.T., and Van Zoonen, P. Coupled Column Liquid Chromotography for the Trace Determination of Polar Pesticides in Water Using Direct Large-Volume Injection: Method Development Strategy Applied to Methyl Isothiocyanate. Anal. Chim. Acta. 1992, 268, 205-215.

Hogge, L.R., Reed, D.W., Underhill, E.W., and G.W. Haughn. HPLC Separation of Glucosinolates from Leaves and Seeds of Arabidopsis thaliana and Their Identification Using Thermospray Liquid Chromatography/Mass Spectrometry. J. Chromatog. Sci. 1988, 26, 551-556.

Höglund, A., Lenman, M., and Rask, L. Myrosinase Is Localized to the Interior of Myrosin Grains and Is Not Associated to the Surrounding Tonoplast Membrane. Plant Sci. 1992, 85, 165-170.

Holley, R.A. and Jones, J.D. The Role of Myrosinase in the Development of Toxicity toward Nematospora in Mustard Seed. Can. J. Bot. 1985, 63, 521-526.

Holmes, M.R.J. Nutrition of Oilseed Rape Crop. 1980, Applied Scientific Publishing Ltd., London, UK.

Hooker, W.J., Walker, J.C., and Smith, F.G. Toxicity of Beta-Phenethyl Isothiocyanate to Certain Fungi. Am. J. Bot. 1943, 30, 632-637.

Horricks, J.S. Influence of Rape Residue on Cereal Production. Can. J. Plant Sci. 1969, 49, 632-634.

Hughes, M.N. General Chemistry. In Chemistry and Biochemistry of Thiocyanic Acid and Its Derivatives. Newman, A.A., Ed.; Academic Press: London 1975, pp. 1-67.

Ilgen, B. and Stamp, P. Root Development in Seedlings of Oilradish, White Mustard and Pea. J. Agron. Crop Sci. 1992, 169, 122-127.

Institute of Food Technologists. Potential Mechanisms for Food-Related Carcinogens and Anticarcinogens. Food Tech. 1993, 47(2), 105-118. 
Ioannou, Y.M., Burka, L.T., and Matthews, H.B. Allyl Isothiocyanate: Comparative Disposition in Rats and Mice. Tech. Appl. Pharm. 1984, 75, 173-181.

Iori, M.M., Leoni, O., Marchi, A. In Vitro Activity of Glucosinolate-Derived Isothiocyanates against Postharvest Fruit Pathogens. Ann. Appl. Biol. 1993, 123, 155-164.

Isshiki, K., Tokuoka, K., Mori, R., and Chiba, S. Preliminary Examination of Allyl Isothiocyanate Vapor for Food Preservation. Biosci. Biotechniol. Biochem. 1992, 56, 1476-1477.

Itoh, H., Yoshida, R., Mizuno, T., Kudo, M., Nikuni, S., and Karki, T. Study on the Contents of Volatile Isothiocyanate of Cultivars of Brassica Vegetables. Rept. Natl. Food Res. Inst. 1984, 45, 33-41.

James, R.L. Personal communication, 2002. USDA Forest Service, 3815 Schreiber Way, Coeur d'Alene, ID 83814.

James, R.L., Page-Dumroese, D.S., Kimball, S.K., and Omi, S. Effects of Brassica Cover Crop, Organic Amendment, Fallowing, and Soil Fumigation on Production of Bareroot Douglas-Fir Seedlings--USDA Forest Service Nursery, Coeur d'Alene, Idaho. 1996, USDA Forest Service, Northern Region, Forest Health Protection Report 96-5.

Jessop, R.S. and Stewart, L.W. Effects of Crop Residues, Soil Type and Temperature on Emergence and Early Growth of Wheat. Plant Soil 1983, 74, 101-109.

Jiménez-Orsornio, J.J. and Gliessman, S.R. Allelopathic Interference in a Wild Mustard (Brassica campestris L.) and Broccoli (Brassica oleracea L. var. italica) Intercrop Agroecosystem. In Allelochemicals: Role in Agriculture and Forestry. American Chemical Society: Washington, D.C. 1987, pp. 262-288.

Johansson, H. Ogräsbekämpning I Grönsaksodling med Vitsenapsexpeller - en Naturlig Herbicid. SLU Info/Trädgård Rapporter 371. Swedish University of Agricultural Sciences: Alnarp 1992.

Johansson, H. and Ascard, J. Ogräsbekämpning med Senapsexpeller Bland Träd och Buskar. Försök med Äpple- och Plommonträd, Svarta Vinbär, Prydnadsbuskar och Gräs. SLU Info/Trädgård Rapporter 379. Swedish University of Agricultural Sciences: Alnarp 1994.

Johnson, A.W., Golden, A.M., Auld, D.L., and Sumner, D.R. Effects of Rapeseed and Vetch as Green Manure Crops and Fallow on Nematodes and Soil-Borne Pathogens. J. Nematol. 1992, 24, 117-126.

Johnston, F.J. Cyanide. In Encyclopedia of Science and Technology. McGraw-Hill: New York 1987, pp. 621.

Johnston, T.D. and Jones, D.I.H. Variations in the Thiocyanate Content of Kale Varieties. $J$. Sci. Food Agric. 1966, 17, 70-71. 
Jones, C.E. Crop Rotation for the Control of Wild Oats in Wheat. In Proceedings 6th Australian Society of Agronomy Conference UNE Armidale, February 1992. 1992, pp. 438441.

Jönsson, R. Erucic-acid heredity in rapeseed (Brassica napus L. and Brassica campestris L.) Hereditas 1977a, 86, 159-170.

Jönsson, R. Breeding for improved oil and meal quality in rape (Brassica napus L.) and turnip rape (Brassica campestris L.). Hereditas 1977b, 87, 205-218.

Josefsson, E. Content of Rhodanidogenic Glucosides in Some Brassica Crops. J. Sci. Food Agric. 1967a, 18, 492-495.

Josefsson, E. Distribution of Thioglucosides in Different Parts of Brassica Plants. Phytochemistry 1967b, 6, 1617-1627.

Josefsson, E. Content of $p$-Hydroxybenzylglucosinolate in Seed Meals of Sinapis alba as Affected by Heredity, Environment and Seed Part. J. Sci. Food Agric. 1970a, 21, 94-97.

Josefsson, E. Glucosinolate Content and Amino Acid Composition of Rapeseed (Brassica napus) Meal as Affected by Sulphur and Nitrogen Nutrition. J. Sci. Food Agric. 1970b, 21, 98-103.

Josefsson, E. Nutritional Value and Use of Rapeseed Meal. In Rapeseed, L.A. Appelqvist and R. Ohlson (ed.). Elsevier Publishing Co., New York. 1972.

Josefsson, E., and Appelqvist, L.Å. Glucosinolates in Seed of Rape and Turnip Rape as Affected by Variety and Environment. J. Sci. Food Agric. 1968, 19, 564-570.

Jourdan P.S., Earle, E.D., and Mutschler, M.A. Synthesis of Male Sterile, Triazine-Resistant Brassica napus by Somatic Hybridization between Cytoplasmic Male Sterile B. oleracea and Atrazine-Resistant B. campestris. Theor. Appl. Genet. 1989, 78, 445-455.

Ju, H.Y., Bible, B.B., and Chong, C. Influence of Ionic Thiocyanate on Growth of Cabbage, Bean, and Tobacco. J. Chem. Ecol. 1983, 8, 1255-1262.

Ju, H.Y., Chong, C., and Bible, B.B. Influence of Boron Nutrition on Glucosinolates and Reducing Sugars of Turnip. Can. J. Plant Sci. 1982, 62, 1037-1042.

Kanemaru, K. and Miyamoto, T. Inhibitory Effects on the Growth of Several Bacteria by Brown Mustard and Allyl Isothiocyanate. Nip. Shok. Kogyo Gak. 1990, 37, 823-829.

Kasting, R., Pittman, U.J., Horricks, J.S., Downey, R.K., and Dubetz, S. Toxin from the Straw Residue of Rape. Abstracts of technical papers presented at the annual meeting of the Canadian Society of Agronomy 1973. Can. J. Plant Sci. 1974, 54, 447. 
Katayama, Y. and Kuraishi, H. Characteistics of Thiobacillus thioparus and Its Thiocyanate Assimilation. Can. J. Microbiol. 1978, 24, 804-810.

Kawakishi, S., Goto, T., and Namiki, M. Oxidative Scission of the Disulfide Bond of Cystine and Polypeptides by the Action of Allyl Isothiocyanate. Agric. Biol Chem. 1983, 47, 20712076.

Kawakishi, S. and Kaneko, T. Interaction of Oxidized Glutathione with Allyl Isothiocyanate. Phytochemistry 1985, 24, 715-718.

Kawakishi, S. and Kaneko, T. Interaction of Proteins with Allyl Isothiocyanate. J. Agric. Food Chem. 1987, 35, 85-88.

Kerlan, M.C., Chèvre, A.M. Eber, F. Baranger, A., and Renard, M. Risk Assessment of Outcrossing of Transgenic Rapeseed to Related Species: I. Interspecific Hybrid Production under Optimal Conditions with Emphasis on Pollination and Fertilization. Euphytica 1992, $62,145-153$.

Kiddle, G.A., Doughty, K.J., and Wallsgrove, R.M. Salicylic Acid-Induced Accumulation of Glucosinolates in Oilseed Rape (Brassica napus L.) Leaves. J. Exp. Bot. 1994, 45, 13431346.

Kingsbury, J.M. Poisonous Plants of the United States and Canada. 1964, Prentice Hall, New York.

Kirkegaard, J.A., Gardner, P.A., Angus, J.F., and Koetz, E. Effect of Brassica Break Crops on the Growth and Yield of Wheat. Aust. J. Agric. Res. 1994, 45, 529-545.

Kirkegaard, J.A., Gardner, P.A., Desmarchelier, J.M., and Angus, J.F. Biofumigation - Using Brassica Species to Control Pests and Diseases in Horticulture and Agriculture. In Proceedings 9th Australian Research Assembly on Brassicas (Wagga Wagga). Wrather, N. and Mailer, R. Eds., 1993, pp. 77-82.

Kirkegaard, J.A., Smith, B.J., and Morra, M.J. Biofumigation: Soil-Borne Pest and Disease Suppression by Brassica roots. In Proceedings of the 6th Symposium of the International Society of Root Research November 11-15, 2001; Nagoya, Japan. Japanese Society for Root Research (JSRR), Nagoya, Japan, 2001, pp. 416-417.

Kirti P.B., Narasimhulu, S.B., Prakash, S., and Chopra, V.P. Production and Characterization of Intergeneric Somatic Hybrids of Trachystoma ballii and Brassica juncea. Plant Cell Rep. 1992, $11,90-92$.

Kjaer, A. Naturally Derived Isothiocyanates (Mustard Oils) and Their Parent Glucosides. In Progress in the Chemistry of Organic Natural Products; Zechmeister, L., Ed., SpringerVerlag: Vienna 1960, pp. 122-176. 
Kjaer, A. Glucosinolates in the Cruciferae. In The Biology and Chemistry of the Cruciferae; Vaughan, J.G., Macleod, A.J., and Jones, B.M.G., Eds., Academic Press: London 1976, pp. 207-219.

Kjaer, A. and Christensen, B.W. Isothiocyanates XL. Glucosisaustricin, a Novel Glucoside Present in Seeds of Sisymbrium austriacum Jacq. Acta Chemica Scand. 1962a, 16, 71-77.

Kjaer, A. and Christensen, B.W. Isothiocyanates XLI. Glucobenzsisaustricin, a New Glucoside Present in Seeds of Sisymbrium austriacum Jacq. Acta Chemica Scand. 1962b, 16, 83-86.

Kjaer, A. and Conti, J. Isothiocyanates V. The Occurrence of Isopropyl Isothiocyanate in Seeds and Fresh Plants of Various Cruciferae. Acta Chem. Scand. 1953, 7, 1011-1012.

Kjaer, A. and Conti, J. Isothiocyanates VII. A Convenient Synthesis of Erysoline ( $\delta$ Methylsulphonylbutyl Isothiocyanate). Acta Chem Scand. 1954, 8, 295-298.

Kjaer, A and Gmelin, R. Isothiocyanates XI. 4-Methylthiobutyl Isothiocyanate, a New Naturally Occurring Mustard Oil. Acta Chem. Scand. 1955, 9, 542-544.

Kjaer, A and Gmelin, R. Isothiocyanates XIX. L(-)-5-Methylsulphinylpentyl Isothiocyanate, the Aglucone of a New Naturally Occurring Glucoside (Glucoalyssin). Acta Chem. Scand. 1956, 10, 1100-1110.

Kjaer, A., Gmelin, R., and Jensen, R.B. Isothiocyanates XV.p-Methoxybenzyl Isothiocyanate, a New Natural Mustard Oil occurring as Glucoside (Glucoaubrietin) in Aubrietia Species. Acta Chem. Scand. 1956a, 10, 26-31.

Kjaer, A., Gmelin, R., and Jensen, R.B. Isothiocyanates XXI. (-)-10-Methylsulphinyldecyl Isothiocyanate, a New Mustard Oil Present as a Glucoside (Glucocamelinin) in Camelina Species. Acta Chem. Scand. 1956b, 10, 1614-1619.

Kjaer, A., Gmelin, R., and Larsen, I. Isothiocyanate XIII. Methyl Isothiocyanate, a New Naturally Occurring Mustard Oil, Present as Glucoside (Glucocapparin) in Capparidaceae. Acta Chem. Scand. 1955, 9, 857-858.

Kjaer, A. and Larsen, I. Isothiocyanate IX. The Occurrence of Ethyl Isothiocyanate in Nature. Acta Chem. Scand. 1954, 8, 699-701.

Kjaer, A. and Larsen, P.O. Non-Protein Amino-Acids, Cyanogenic Glycosides, and Glucosinolates. In Biosynthesis; Geissman, T.A. Ed., The Chemical Society: London 1973, pp. 71-105.

Kjaer, A., Madsen J.Ø., Maeda, Y., Ozawa, Y., and Uda, Y. Volatiles in Distillates of Fresh Radish of Japanese and Kenyan Origin. Agric. Biol. Chem. 1978, 42, 1715-1721. 
Kjaer, A., Malver, O., El-Menshaw, B., and Reisch, J. Isothiocyanates in Myrosinase-Treated Seed Extracts of Moringa peregrina. Phytochemistry 1979, 18, 1485-1487.

Kjaer, A. and Schuster, A. Glucosinolates in Erysimim hieracifolium L.; Three New, Naturally Occurring Glucosinolates. Acta Chem. Scand. 1970, 24, 1631-1638.

Kjaer, A. and Schuster, A. Glucosinolates in Capparis flexuosa of Jamaican Origin. Phytochemistry 1971, 10, 3155-3160.

Kjaer, A. and Schuster, A. Glucosinolates in Seeds of Arabis hirsuta (L.) Scop.: Some New, Naturally Derived Isothiocyanates. Acta Chem. Scand. 1972, 26, 8-14.

Kjaer, A. and Schuster, A. $\omega$-Methylthioalkylglucosinolates and Some Oxidized Congeners in Seeds of Erysimum rhaeticum. Phytochemistry 1973, 12, 929-933.

Kjaer, A. and Thomsen, H. Isothiocyanates XLII. Glucocleomin, a New Natural Glucoside, Furnishing (-)-5-Ethyl-5-methyl-2-oxazolidinethione on Enzymic Hydrolysis. Acta Chem. Scand. 1962, 16, 591-598.

Kjaer, A. and Thomsen, H. Isothiocyanate-producing Glucosides in Species of Capparidaceae. Phytochemistry 1963a, 2, 29-32.

Kjaer, A. and Thomsen, H. Gluconorcappasalin, a Thioglucoside Producing 5-Oxoheptyl Isothiocyanate on Enzymic Hydrolysis. Acta Chem. Scand. 1963b, 17, 561-562.

Kjaer, A. and Wagnières. 3-Methyl-3-butenylglucosinolate, a New Isothiocyanate-Producing Thioglucoside. Acta Chem. Scand. 1965, 19 1989-1991.

Kondo, H., Kawaguchi, T., Naoshima, Y., and Nozaki, H. Changes in Volatile Components of Rape Seeds (Brassica napus L.) during Germination. Agric. Biol. Chem. 1985, 49, $217-$ 219.

Kondra, Z.P. and Stefansson, B.R. Inheritance of Erucic Acid and Eicosenoic Acid Content in Rapeseed Oil (B. napus). Can. J. Genet. Cyto. 1965, 7, 505-510.

Kondra, Z.P. and Stefansson, B.R. Inheritance of the Major Glucosinolates of Rapeseed (Brassica napus) meal. Can. J. Pl. Sci. 1970, 50, 643-647.

Koritsas, V.M., Lewis, J.A., and Fenwick, G.R. Accumulation of Indole Glucosinolates in Psylliodes chroysocephala L. -Infested, or -Damaged Tissues of Oilseed Rape (Brassica napus L.). Experientia 1989, 45, 493-495.

Koritsas, V.M., Lewis, J.A., and Fenwick, G.R. Glucosinolate Responses of Oilseed Rape, Mustard and Kale to Mechanical Wounding and Infestation by Cabbage Stem Flea Beetle. Ann. Appl. Biol. 1991, 118, 209-221. 
Kücke, M. The Efficiency of Rapeseed Oil Cake as Fertilizer. Agribiol. Res. 1993, 46, 269276.

Kutácek, M. Glucobrassicin a Potential Inhibitor of Unusual Type Affecting the Germination and Growth of Plants; Mechanism of Its Action. Biol. Plantarum 1964, 6, 88-98.

Kyung, K.M. and Fleming, H.P. Antibacterial Activity of Cabbage Juice against Lactic Acid Bacteria. J. Food Sci. 1994, 59, 125-129.

Lam, W.W., Kim, J.H., Sparks, S.E., Quistad, G.B., and Casida, J.E. Metabolism in Rats and Mice of the Soil Fumigants Metham, Methyl Isothiocyanate, and Dazomet. J. Agric. Food Chem. 1993, 41, 1497-1502.

Lammerink, J., MacGibbon, D.B., and Wallace, D.B. Effect of the Cabbage Aphid (Brevicoryne brassicae) on Total Glucosinolate in the Weed of Oilseed Rape (Brassica napus). New Zea. J. Agric. Res. 1984, 27, 89-92.

Landis, D.A. and Gould, F. Screening for Phyto-Protectants to Guard Corn Seeds/Seedlings from Southern Corn Rootworm Feeding Injury. J. Entomol. Sci. 1988, 23, 201-211.

Larsen, P.O. Glucosinolates. In The Biochemistry of Plants, 7, Secondary Plant Products; Conn E.E., Ed., Academic Press: New York 1981, pp. 501-525.

Lazzeri, L., Tacconi, R., and Palmieri, S. In Vitro Activity of Some Glucosinolates and Their Reaction Products toward a Population of the Nematode Heterodera schachtii. J. Agric. Food Chem. 1993, 41, 825-829.

Leather, G.R. Weed Control Using Allelopathic Crop Plants. J. Chem. Ecol. 1983, 9, 983989.

Leblová-Svobodová, S. and Koštír, J. Action of Isothiocyanates on Germinating Plants. Experientia 1962, 18, 554-555.

Lefol, E., and Darmency, H. Risk of Intergeneric Gene Transfer from Transgenic Canola to Wild Weedy Relatives. In Proc. Eighth Crucifer Genetics Workshop. Saskatoon, SK. July 21-24 1993, p. 56.

Lehman, R.S. Laboratory Tests of Organic Fumigants for Wireworms. J. Econ. Entomol. 1942, 35, 659-661.

Lenman, M., Rödin, J., Josefsson, L., and Rask, L. Immunological Characterization of RapeSeed Myrosinase. Eur. J. Biochem. 1990, 194, 747-753.

Lenman, M., Falk, A., Rödin, J., Höglund, A., Ek., B., and Rask, L. Differential Expression of Myrosinase Gene Families. Plant Physiol. 1993a. 103, 703-711. 
Lenman, M., Falk, A., Xue, J., and Rask, L. Characterization of a Brassica napus Myrosinase Psuedogene: Myrosinases Are Members of the BGA Family of B-Glycosidases. Plant Mol. Biol. 1993b, 21, 463-474.

Leistra, M., Smelt, J.H., and Nollen, H.M. Concentration-Time Relationships for Methyl Isothiocyanate in Soil after Injection of Metham-Sodium. Pestic. Sci. 1974, 5, 409-417.

Levin, D.A. Plant Phenolics: An Ecological Perspective. Amer. Naturalist 1971, 105, $157-$ 181.

Lewis, J.A. and Papavizas, G.C. Evolution of Volatile Sulfur-Containing Compounds from Decomposition of Crucifers in Soil. Soil Biol. Biochem. 1970, 2, 239-246.

Lewis, J.A. and Papavizas, G.C. Effect of Sulfur-Containing Volatile Compounds and Vapors from Cabbage Decomposition on Aphanomyces euteiches. Phytopathology 1971, 61, 208-214.

Lewis, J.A. and Papavizas, G.C. Effect of Volatiles from Decomposing Plant Tissues on Pigmentation, Growth, and Survival of Rhizoctonia solani. Soil Sci. 1974, 118, 156-163.

Lichtenstein, E.P., Morgan, D.G., and Mueller, C.H. Naturally Occurring Insecticides in Cruciferous Crops. J. Agric. Food Chem. 1964, 12, 158-161.

Lichtenstein, E.P., Strong, F.M., and Morgan, D.G. Identification of 2-Phenylethylisothiocyanate as an Insecticide Occurring Naturally in the Edible Part of Turnips. Agric. Food Chem. 1962, 10, 30-33.

Loub, W.D., Wattenberg, L.W., and Davis, D.W. Aryl Hydrocarbon Hdroxylase Induction in Rat Tissues by Naturally Occurring Indoles of Cruciferous Plants. J. Natl. Cancer Inst. 1975, $54,985-987$.

Louda, S.M., Farris, M.A., and Blua, M.J. Variation in Methylglucosinolate and Insect Damage to Cleome serrulata (Capparaceae) along a Natural Soil Moisture Gradient. $J$. Chem. Ecol. 1987, 13, 569-581.

Louda, S.M. and Rodman, J.E. Concentration of Glucosinolates in Relation to Habitat and Insect Herbivory for the Native Crucifer Cardamine cordifolia. Biochem. Sys. Ecol. 1983, 11 199-207.

Love, H.K., Rakow, G. Raney, J.P., and Downey, R.K. Genetic Control of 2-Propenyl and 3-Butenyl Glucosinolate Synthesis in Mustard. Can. J. Pl. Sci. 1990, 70, 425-429.

Lovett, J.V. and Duffield, A.M. Allelochemicals of Camelina sativa. J. Appl. Ecol. 1981, 18, 283-290. 
Lovett, J.V. and Jackson, H.F. Allelopathic Activity of Camelina sativa (L.) Crantz in Relation to Its Phyllosphere Bacteria. New Phytol. 1980, 86, 273-277.

Lüthy, B. and Matile, P. The Mustard Oil Bomb: Rectified Analysis of the Subcellular Organisation of the Myrosinase System. Biochem. Physiol. Pflanzen 1984, 179, 5-12.

Lüthy, J., Carden, B., Friederich, U., and Bachmann, M. Goitrin - a Nitrosatable Constituent of Plant Foodstuffs. Experientia 1984, 40, 452-453.

Lykkesfeldt, J. and Møller, B.L. Synthesis of Benzylglucosinolate in Tropaeolum majus L. Isothiocyanates as Potent Enzyme Inhibitors. Plant Physiol. 1993, 102, 609-613.

Macfarlane-Smith, W.H., and Griffiths, D.W. A Time-Course Study of Glucosinolates in the Ontogeny of Forage Rape (Brassica napus L). J. Sci. Food Agric. 1988, 43, 121-134.

Macfarlane-Smith, W.H., Griffiths, D.W., and Boag, B. Overwinter Variation in Glucosinolate Content of Green Tissue of Rape (Brassica napus) in Response to Grazing by Wild Rabbit (Oryctolagus cuniculus). J. Sci. Food Agric. 1991, 56, 511-521.

MacLeod, A.J. and Nussbaum, M.L. The Effects of Different Horticultural Practices on the Chemical Flavour Composition of Some Cabbage Cultivars. Phytochemistry 1977, 16, 861865.

MacLeod, A.J., Panesar, S.S., and Gil, V. Thermal Degradation of Glucosinolates. Phytochemistry 1981, 20, 997-980.

MacLeod, A.J. and Rossiter, J.T. The Occurrence and Activity of Epithiospecifier Protein in Some Cruciferae Seeds. Phytochemistry 1985, 24, 1895-1898.

MacLeod, A.J. and Rossiter, J.T. Isolation and Examination of Thioglucoside Glucohydrolase from Seeds of Brassica napus. Phytochemistry 1986, 25, 1047-1051.

Mailer, R.J. and Pratley, J.E. Field Studies of Moisture Availability Effects on Glucosinolate and Oil Concentration in the Seed of Rape (Brassica napus L.) and Turnip Rape (Brassica rapa L. var. silvestris (Lam.) Briggs). Can J. Plant Sci. 1990, 70, 339-407.

Manici, L.M., L. Lazzeri, G. Baruzzi, O. Leoni, S. Galletti, and S. Palmieri. Suppressive Activity of Some Glucosinolate Enzyme Degradation Products on Pythium irregulare and Rhizoctonia solani in Sterile Soil. Pest Manag. Sci. 2000, 56, 921-926.

Marks, H.S., Hilson, J.A., Leichtweis, H.C., and Stoewsand, G.S. S-Methylcysteine Sulfoxide in Brassica Vegetables and Formation of Methyl Methanethiosulfinate from Brussels Sprouts. J. Agric. Food Chem. 1992, 40, 2098-2101.

Maruyama, F.T. Identification of Dimethyl Trisulfide as a Major Aroma Component of Cooked Brassicaceous Vegetables. J. Food Sci. 1970, 35, 540-543. 
Mason-Sedun, W. and Jessop, R.S. Differential Phytotoxicity among Species and Cultivars of the Genus Brassica to Wheat. II. Activity and Persistence of Water-Soluble Phytotoxins from Residues of the Genus Brassica. Plant and Soil 1988, 107, 69-80.

Mason-Sedun, W., Jessop, R.S., and Lovett, J.V. Differential Phytotoxicity among Species and Cultivars of the Genus Brassica to Wheat. I. Laboratory and Field Screening of Species. Plant and Soil 1986, 93, 3-16.

Matthiessen, J.N., Desmarchelier, J.M., Vu, L.T., and Shackleton, M.A. Comparative Efficacy of Fumigants against Hatchling Whitefringed Beetle Larvae. J. Econ. Entom. 1996, $89,1372-1378$.

Matthiessen, J.N. and Shackleton, M.A. Advantageous Attributes of Larval Whitefringed Weevil, Naupactus leucoloma (Coleoptera:Curculionidae) for Bioassaying Soil Fumigants, and Responses to Pure and Plant-Derived Isothiocyanates. Bull. Entomol. Res. 2000, 90, 349355.

Mayton, H.S., Oliver, C., Vaughn, S.F., and Loria, R. Correlation of Fungicidal Activity of Brassica Species with Allyl Isothiocyanate Production in Macerated Leaf Tissue.

Phytopathology 1996, 86, 267-271.

McCaffrey, J.P., Williams, L. III, Borek, V., Brown, P.D., and Morra, M.J. Toxicity of Ionic Thiocyanate-Amended Soil to the Wireworm, Limonius californicus (Coleoptera:

Elateridae). J. Econ. Entomol. 1995, 88, 793-797.

McCloskey, C. and Isman, M.B. Influence of Foliar Glucosinolates in Oilseed Rape and Mustard on Feeding and Growth of the Bertha Armyworm, Mamestra configurata Walker. J. Chem. Ecol. 1993, 19, 249-266.

McDanell, R, McLean, A.E.M., Hanley, A.B., and Fenwick, G.R. Chemical and Biological Properties of Indole Glucosinolates (Glucobrassicins): A Review. Fd. Chem. Toxic. 1988, 26, 59-70.

McGregor, D.I., Mullin, W.J., and Fenwick, G.R. Analytical Methodology for Determining Glucosinolate Composition and Content. J. Assoc. Off. Anal. Chem. 1983, 66, 825-849.

McNaughton, I.H. Swedes and Rapes. Evolution of Crop Plants. N.M. Simmonds, ed. Longman Group Limited. London. 1972, pp. 53-56.

McKay, A.F., Garmaise, D.L., Gaudry, R., Baker, H.A., Paris, G.Y., Kay, R.W., Just, G.E., and Schwartz, R. Bacteriostats. II. The Chemical and Bacteriostatic Properties of Isothiocyanates and Their Derivatives. J. Amer. Chem. Soc. 1959, 81, 4328-4335.

Mennicke, W.H., Görler, K., and Krumbiegel, G. Metabolism of Some Naturally Occurring Isothiocyanates in the Rat. Xenobiotica 1983, 13, 203-207. 
Mennicke, W.H., Görler, K., Krumbiegel, G., Lorenz, D., and Rittmann, N. Studies on the Metabolism and Excretion of Benzyl Isothiocyanate in Man. Xenobiotica 1988, 18, 441-447.

Metz P.L., Jacobsen, E. Nap, J.P., Pereira, A., and Stiekema, W.J. The Impact on Biosafety of the Phosphinothricin-Tolerance Transgene in Inter-Specific B. rapa $\mathrm{x}$ B. napus Hybrids and Their Successful Backcrosses. Theor. Appl. Gen. 1997, 95, 442-452.

Migirab, S. El., Berger, Y., and Jadot, J. Isothiocyanates, Thiourees et Thiocarbamates Isoles de Pentadiplandra Brazzeana. Phytochemistry 1977, 16, 1719-1721.

Milford, G.F.J., Porter, A.J.R., Fieldsend, J.K., Miller, C.A., Leach, J.E., and Williams, I.H. Glucosinolates in Oilseed Rape (Brassica napus) and the Incidence of Pollen Beetles (Meligethes aeneus). Ann. Appl. Biol. 1989, 115, 375-380.

Miller, D.B. Determination of Methylisothiocyanate by an HPLC Trapping and Derivatization Procedure. $L C$ GC 1988, 6, 842-846.

Minami, K. Volatilization of Sulfur from Paddy Soils. Jap. Agric. Res. Quart. 1982, 15, 167171.

Minami, K. and Fukushi, S. Volatilization of Carbonyl Sulfide from Paddy Soils Treated with Sulfur-Containing Substances. Soil Sci. Plant Nutr. 1981, 27, 339-345.

Minchinton, I., Sang, J., Burke, D., and Truscott, R.J.W. Separation of Desulphoglucosinolates by Reversed-Phase High-Performance Liquid Chromatography. J. Chromatog. 1982, $247,141-148$.

Mithen, R. Leaf Glucosinolate Profiles and Their Relationship to Pest and Disease Resistance in Oilseed Rape. Euphytica 1992, 63, 71-83.

Mithen, R.F., Lewis, B.B., Heaney, R.K., and Fenwick, G.R. Resistance of Leaves of Brassica Species to Leptosphaeria maculans. Trans. Br. Mycol. Soc. 1987, 88, 525-531.

Mithen, R.F., Lewis, B.G., and Fenwick, G.R. In Vitro Activity of Glucosinolates and Their Products against Leptosphaeria maculans. Trans. Br. mycol. Soc. 1986, 87, 433-440.

Mojtahedi, H., Santo, G.S., Hang, A.N., and Wilson, J.H. Suppression of Root-Knot Nematode Populations with Selected Rapeseed Cultivars as Green Manure. J. Nematol. 1991, 23, 170-174.

Monde, K., Sasaki, K., Shirata, A., and Takasugi, M. Brassicanal C and Two Dioxindoles from Cabbage. Phytochemistry 1991, 30, 2915-2917.

Morra, M.J. and Johnson-Maynard, J. Unpublished data, 2003. Soil \& Land Resources Division, University of Idaho, Moscow ID 83844. 
Morra, M.J. and Kirkegaard, J.A. Isothiocyanate Release from Soil-Incorporated Brassica Tissues. Soil Biol. Biochem. 2002, 34, 1683-1690.

Mossoba, M.M., Shaw, G.J., Andrzejewski, D., Sphon, J.A., and Page, S.W. Application of Gas Chromatography/Matrix Isolation/Fourier Transform Infrared Spectrometry to the Identification of Glucosinolates from Brassica Vegetables. J. Agric. Food Chem. 1989, 37, 367-372.

Muehlchen, A.M., Rand, R.E., and Parke, J.L. Evaluation of Crucifer Green Manures for Controlling Aphanomyces Root Rot of Peas. Plant Disease 1990, 74, 651-654.

Mullins, F.G.P. and Kirkbright, G.F. Determination of Sodium N-Methyldithiocarbamate (Metham-Sodium) and Methyl Isothiocyanate in Aqueous Samples by High-Performance Liquid Chromatography Using a Micellar Mobile Phase. Analyst 1987, 112, 701-703.

Munnecke, D.E., Domsch, K.H., and Eckert, J.W. Fungicidal Activity of Air Passed through Columns of Soil Treated with Fungicides. Phytopathology 1962, 52, 1298-1306.

Munnecke, D.E. and Martin, J.P. Release of Methylisothiocyanate from Soils Treated with Mylone (3,5-dimethyl-tetrahydro-1,3,5,2H-thiadiazine-2-thione). Phytopathology 1964, 54, 941-945.

Musk, S.R.R. and Johnson, I.T. The Clastrogenic Effects of Isothiocyanates. Mutat. Res. 1993, 300, 111-117.

Nastruzzi, C., Cortesi, R., Esposito, E., Menegatti, E., Leoni, O., Iori, R., and Palmieri, S. In vitro Cytotoxic Activity of Some Glucosinolate-Derived Products Generated by Myrosinase Hydrolysis. J. Agric. Food Chem. 1996, 44, 1014-1021.

Nawaz, M.S., Franklin, W., Campbell, W.L., Heinze, T.M., and Cerniglia, C.E. Metabolism of Acrylonitrile by Klebsiella pneumoniae. Arch. Microbiol. 1991, 156, 231-238.

Nawaz, M.S., Heinze, T.M., and Cerniglia, C.E. Metabolism of Benzonitrile and Butyronitrile by Klebsiella pneumoniae. Appl. Environ. Microbiol. 1992, 58, 27-31.

Nishiyama, I., Sarashima, M., and Matsuzawa, Y. Critical Discussion on Abortive Interspecific Crosses in Brassica. Plant Breed. Z Pflanzenzucht. 1991, 107, 288-302.

Oleszek, W. Allelopathic Effects of Volatiles from Some Cruciferae Species on Lettuce, Barnyard Grass and Wheat Growth. Plant and Soil 1987, 102, 271-273.

Oleszek, W., Ascard, J., and Johansson, H. Cruciferae as Alternative Plants for Weed Control in Sustainable Agriculture. In Abstract Book from the International Symposium "Allelopathy in Sustainable Agriculture, Forestry and Environment." Narwal, S.S., Tauro, P., Dhaliwal, G.S., and Prakash, J., Ed.; Indian Society of Allelopathy: New Delhi 1994, p. 160. 
Olsen, O. and Sørensen, H. Isolation of Glucosinolates and the Identification of $o-(\alpha-\mathrm{L}-$ Rhamnopyranosyloxy)benzylglucosinolate from Reseda odorata. Phytochemistry 1979, 18, 1547-1552.

Olsen, O. and Sørensen, H. Glucosinolates and Amines in Reseda Media. Phytochemistry 1980, 19, 1783-1787.

Olsen, O., Rasmussen, K.W., and Sørensen, H. Glucosinolates in Sesamoides canescens and S. pygmaea: Identification of 2-( $\alpha$-L-Arabinopyranosyloxy)-2-Phenylethylglucosinolate. Phytochemistry 1981, 8, 1857-1861.

Ostermayer, F. and Tarbell, D.S. Products of Acidic Hydrolysis of S-Methyl-L-Cysteine Sulfoxide; the Isolation of Methyl Methanethiolsulfonate, and Mechanism of the Hydrolysis. J. Am. Chem. Soc. 1960, 82, 3752-3755.

Owino, P.O., Waudo, S.W., and Sikora, R.A. Biological Control of Meloidogyne javanica in Kenya: Effect of Plant Residues, Benomyl and Decomposition Products of Mustard (Brassica campestris). Nematologica 1993, 39, 127-134.

Papavizas, G.C. Suppression of Aphanomyces Root Rot of Peas by Cruciferous Soil Amendments. Phytopathology 1966, 56, 1071-1075.

Papavizas, G.C. and Lewis, J.A. Effect of Amendments and Fungicides on Aphanomyces Root Rot of Peas. Phytopathology 1971, 61, 215-220.

Park, K.W., Hwang, S.K., Choi, S.J., and Kim, Y.S. Effect of Thiocyante Ion and Boron on the Germination of Several Vegetable Crops. Chem Abst. 1983, 99, 83659q.

Parke, J.L. and Rand R.E. Incorporation of Crucifer Green Manures to Reduce Aphanomyces Root Rot of Snap Beans. Annu. Rep. Bean Improv. Coop. 1989, 32, 105-106.

Patrick, Z.A., Toussoun, T.A., and Snyder, W.C. Phytotoxic Substances in Arable Soils Associated with Decomposition of Plant Residues. Phytopathology 1963, 53, 152-161.

Pawlowski, S.H., Riegert, P.W., and Krzymanski, J. Use of Grasshoppers in Bioassay of Thioglucosides in Rapeseed (Brassica napus). Nature 1968, 220, 174-175.

Paxman, P.J. and Hill, R. Thiocyanate Content of Kale. J. Sci. Food Agric. 1974, 25, 323328.

Perkins, L.A.., Peterson, C.L., and Auld, D.L. Durability Testing of Transesterified Winter Rape Oil (Brassica napus L.) as Fuel in Small Bore, Multi-Cylinderr, DI, CI Engines. SAE Technical Paper Series, 911764. SAE International: Warrendale, PA, USA 1991. 
Peterson, C.L., Auld, D.L., and Korus, R.A. Winter Rape Oil Fuel for Diesel Engines: Recovery and Utilization. J. Amer. Oil Chem. Soc. 1983, 60, 1579-1587.

Petroski, R.J. and Kwolek, W.F. Interactions of a Fungal Thioglucoside Glucohydrolase and Cruciferous Plant Epithiospecifier Protein to Form 1-Cyanoeptihioalkanes: Implications of an Allosteric Mechanism. Phytochemistry 1985, 24, 213-216.

Petroski, R.J. and Tookey, H.L. Interactions of Thioglucoside Glucohydrolase and Epithiospecifier Protein of Cruciferous Plants to Form 1-Cyanoepithioalkanes. Phytochemistry 1982, 8 1903-1905.

Phipps, P.M. Control of Cylindrocladium Black Rot of Peanut with Soil Fumigants Having Methyl Isothiocyanate as the Active Ingredient. Plant Disease 1990, 74, 438-441.

Pieczarka, S.J. and Warren, G.F. The Influence of Concentration of Fumigant and Time of Exposure on the Killing of Dormant Imbibed Seeds. Weeds 1960, 8, 612-615.

Pivnick, K.A., Reed, D.W., Millar, J.G., and Underhill, E.W. Attraction of Northern False Chinch Bug Nysius niger (Heteroptera: Lygaeidae) to Mustard Oils. J. Chem. Ecol. 1991, 17, 931-941.

Pocock, J.J., Heaney, R.K., Wilkinson, A.P., Beaumont, J.E., Vaughan, J.G., and Fenwick, G.R. Changes in Myrosinase Activity and Isoenzyme Pattern, Glucosinolate Content and the Cytology of Myrosin Cells in the Leaves of Heads of Three Cultivars of English White Cabbage. J. Sci. Food Agric. 1987, 41, 245-257.

Pollack, J.J., Goodman, H., Elsey, P.K., and Iacono, V. Synergism of Lysozyme, Proteases and Inorganic Monovalent Anions in the Bacteriolysis of Oral Streptococcus mutans GS5. Chem. Abst. 1983, 99, 20967m.

Powell, R.G. and Spencer, G.F. Phytochemical Inhibitors of Velvetleaf (Abutilon theophrasti) Germination as Models for New Biorational Herbicides. In Biologically Active Natural Products: Potential Use in Agriculture. Cutler, H.G. Ed., American Chemical Society: Washington, D.C., 1988, pp. 211-229.

Putilina, N.T. Bacteria of Sewage Waters of Coke Factories Oxidizing Thiocyanide and Cyanide Compounds. Mikrobiologiya 1961, 30, 294-298.

Quinsac, A., Ribaillier, D., Elfakir, C., Lafosse, M., and Dreux, M. A New Approach to the Study of Glucosinolates by Isocratic Liquid Chromatography. Part 1. Rapid Determination of Desulfated Derivatives of Rapeseed Glucosinolates. J. Assoc. Off. Anal. Chem. 1991, 74, 932-939.

Rafiullah, S. Use of Diallel Analysis to Determine the Inheritance of Agronomic and Quality Traits in Yellow Mustard (Brassica hirta (L) Moench). 1994, Ph.D. Dissertation, University of Idaho 19. 
Ramirez-Villapudua, J. and Munnecke, D.E. Control of Cabbage Yellows (Fusarrium oxysporum f. sp. conglutinans) by Solar Heating of Field Soils Amended with Dry Cabbage Residues. Plant Disease 1987, 71, 217-221.

Ramirez-Villapudua, J., and Munnecke, D.E. Effect of Solar Heating and Soil Amendments of Cruciferous Residues on Fusarrium oxysporum f. sp. conglutinans and Other Organisms. Phytopathology 1988, 78, 289-295.

Ringdahl E.A., McVetty, P.B.E., and Sernyk, A.L. Intergeneric Hybridization of Diplotaxis spp. with Brassica napus: A Source of New CMS Systems? Can. J. Plant Sci. 1987, 67, 239-243.

Röbbelen, G. and Theis, W. Variation in Rapeseed Glucosinolates and Breeding for Improved Meal Quality. In Brassica Crops and Wild Allies Biology and Breeding (S. Tsunoda, K Hinata, and C. Gómez-Campo, Eds.), Japan Scientific Societies Press, Tokyo 1980, pp. 285-299.

Rodman, J.E. and Chew, F.S. Phytochemical Correlates of Herbivory in a Community of Native and Naturalized Cruciferae. Phytochem. Sys. Ecol. 1980, 8, 43-50.

Roine, P., Uksila, E., Teir, H., and Ropola, J. Histopathological Changes in Rats and Pigs Fed Rapeseed Oil. Zeitschrift fur Ernahrungswissenschaft 1960, 1, 118-124.

Rosa, E.A.S., Heaney, Fenwick, G.R., and Portas, C.A.M. Glucosinolates in Crop Plants. Hort. Rev. 1997, 19, 99-215.

Rutkowski, A., Bielecka, M., Kornacka, D., Kozlowska, H., and Roezniakowa, B. Rapeseed Meal XX. Influence of Toxic Compounds of Rapeseed Meal on the Technological Properties of Propionic Acid Bacteria. Can. Inst. Food Sci. Technol. J. 1972, 5, 67-71.

Sang, J.P., Minchinton, I.R., Johnstone, P.K., and Truscott, R.J.W. Glucosinolate Profiles in the Seed, Root and Leaf Tissue of Cabbage, Mustard, Rapeseed, Radish and Swede. Can. J. Plant Sci. 1984, 64, 77-93.

Scarisbrick, D.H. and Daniels, R.W. Oilseed Rape. Williams Collins \& Sons Co. Ltd., 1986.

Schnug, E. and Ceynowa, J. Phytopathological Aspects of Glucosinolates in Oilseed Rape. $J$. Agron. Crop Sci. 1990, 165, 319-328.

Schraudolf, H. and Bäuerle, R. ${ }^{1} \mathrm{~N}$-Acetyl-3-Indolylmethylglucosinolate in Seedlings of Tovaria pendula Ruiz et Pav. Z. Naturforsch. 1986, 41c, 526-528.

Schreiner, R.P. and Koide, R.T. Antifungal Compounds from the Roots of Mycotrophic and Non-Mycotrophic Plant Species. New Phytol. 1993a, 123, 99-105. 
Schreiner, R.P. and Koide, R.T. Mustards, Mustard Oils and Mycorrhizas. New Phytol. 1993b, 23, 107-113.

Seo, S.T. and Tang, C.S. Hawaiian Fruit Flies (Diptera: Tephritidae): Toxicity of Benzyl Isothiocyanate against Eggs or 1st Instars of Three Species. J. Econ. Entomol. 1982, 75, 1132-1135.

Shahidi, F. and Naczk, M. An Overview of the Phenolics of Canola and Rapeseed: Chemical, Sensory and Nutritional Significance. J. Am. Oil. Chem. Soc. 1992, 69, 917-924.

Shaw, G.J., Andrzejewski, D., Roach, J.A.G., and Sphon, J.A. Separation and Identification of Glucosinolates from Brassica Vegetables Using High-Performance Capillary Gas Chromatography (GC)-Positive-Ion Chemical Ionization Mass Spectrometry (PICIMS) and GC-PICIMS/MS. J. Agric. Food Chem. 1989, 37, 372-378.

Shaw, P.E., Ammons, J.M., and Braman, R.S. Volatile Sulfur Compounds in Fresh Orange and Grapefruit Juices: Identification, Quantitation, and Possible Importance to Juice Flavor. J. Agric. Food Chem. 1980, 28, 778-781.

Shahidi, F. Rapeseed and Canola: Global Production and Distribution. In Canola and Rapeseed. Production, Chemistry, Nutrition and Processing Technology. F. Shahidi, Ed., Van Nostrand Reinhold: New York, 1990, pp. 3-13.

Sikdar S.R., Chatterjee, S. Das, and Sen, S.K. "Erussica," the Intergeneric Fertile Somatic Hybrid Developed through Protoplast Fusion between Eruca sativa Lam. and Brassica juncea L. Czern. Theor. Appl. Genet. 1990, 79, 561-567.

Singleton, V.L. and Kratzer, F.H. Plant Phenolics. In Toxicants Occurring Naturally in Foods. National Academy of Sciences: Washington, D.C. 1973, pp. 309-345.

Sirons, G.J. Gas-Liquid Chromatographic Determination of Methyl Isothiocyanate in Soils. J. Assoc. Off. Anal. Chem. 1973, 56, 41-44.

Sittig, M. Handbook of Toxic and Hazardous Chemicals and Carcinogens. Noyes Publications: Park Ridge, N.J., 1985.

Sjodin C. and Glimelius, K. Brassica naponigra, a Somatic Hybrid Resistant to Phoma lingam. Theor. Appl. Genet. 1989, 77, 651-656.

Smelt, J.H., Crum, S.J.H., and Teunissen, W. Accelerated Transformation of the Fumigant Methyl Isothiocyanate in Soil after Repeated Application of Metham-Sodium. J. Environ. Sci. Health 1989, B24, 437-455.

Smelt, J.H. and Leistra, M. Conversion of Metham-Sodium to Methyl Isothiocyanate and Basic Data on the Behaviour of Methyl Isothiocyanate in Soil. Pestic. Sci. 1974, 5, 401-407. 
Smiley, R.A. Nitriles. In Encyclopedia of Chemical Technology. John Wiley and Sons: New York 1979, pp. 888-909.

Smissman, E.E., Beck, S.D., and Boots, M.R. Growth Inhibition of Insects and a Fungus by Indole-3-Acetonitrile. Science 1961, 133, 462.

Smith, N.R., Dawson, V.T., and Wenzel, M.E. The Effect of Certain Herbicides on Soil Microorganisms. Soil Sci. Soc. Proc. 1945, 10 197-201.

Smith, N.A. and Kelly, D.P. Isolation and Physiological Characterization of Autotrophic Sulphur Bacteria Oxidizing Dimethyl Disulphide as Sole Source of Energy. J. Gen. Microbiol. 1988, 134, 1407-1417.

Smolinska, U., Morra, M.J., Knudsen, G.R., and Brown, P. D. Toxicity of Glucosinolate Degradation Products from Brassica napus Seed Meal towards Aphanomyces euteiches F. sp. Pisi. Phytopathology 1997a, 87, 77-82.

Smolinska, U., Knudsen, G.R., Morra, M.J., and Borek, V. Inhibition of Aphanomyces euteiches F. sp. pisi by volatiles produced by hydolysis of Brassica napus seed meal. Plant Dis. 1997b, 81, 288-292.

Smolinska, U., Morra, M.J., Knudsen, G.R., and James, R.L. Isothiocyanates Produced by Brassicaceae Species as Inhibitors of Fusarium oxysporum. Plant Dis. 2003, 87, 407-412.

Sørensen, H. Glucosinolates: Structure-Properties-Function. In Canola and Rapeseed. Shahidi, F., Ed., Van Nostrand Reinhold: New York 1990, pp. 149-172.

Song, K.M., Osborn, T.C., and Williams, P.H. Brassica Taxonomy Based on Nuclear Restriction Fragment Length Polymorphisms (RFLPs). Theor. Appl. Genet. 1988, 75, 784-794.

Sosulski, F.W. and Dabrowski, K.J. Determination of Glucosinolates in Canola Meal and Protein Products by Desulfation and Capillary Gas-Liquid Chromatography. J. Agric. Food Chem. 1984, 32, 1172-1175.

Stafford, D.A. and Callely, A.G. The Utilization of Thiocyanate by a Heterotrophic Bacterium. J. Gen. Microbiol. 1969, 55, 285-289.

Stahmann, M.A., Link, K.P., and Walker, J.C. Mustard Oils in Crucifers and Their Relation to Resistance to Clubroot. J. Agric. Res. 1943, 67, 40-63.

Stefansson, B.R., and Hougen, F.W. Selection of Rape Plants (Brassica napus) with Seed Oil Practically Free of Erucic Acid. Can. J. Plant Sci. 1964, 44, 359-364.

Stefansson, B.R., and Kondra, Z.P. Tower Summer Rape. Can. J. Pl. Sci. 1975, 55, 343-344. 
Stewart, W.S. A Plant Growth Inhibitor and Plant Growth Inhibition. Bot. Gaz. 1939, 101, 91-108.

Stiehl, B. and Bible, B.B. Reaction of Crop Species to Thiocyanate Ion Toxicity. HortScience 1989, 24, 99-101.

Strayer, R.C., Blake, J.A., and Craig, W.K. Canola and High Erucic Rapeseed Oil as Substitutes for Diesel Fuel: Preliminary Tests. J. Amer. Oil Chem. Soc. 1983, 60, 1587-1592.

Tabatabai, M.A. and Singh, B.B. Rhodanese Activity in Soils. Soil Sci. Soc. Am. J. 1976, 40, 381-385.

Taipalensuu, J., Falk, A., and Rask, L. A Wound- and Methyl Jasmonate-Inducible Transcript Coding for a Myrosinase-Associated Protein with Similarities to an Early Nodulin. Plant Physiol. 1996, 110, 483-491.

Takasugi, M., Monde, K., Katsui, N., and Shirata, A. Novel Sulfur-Containing Phytoalexins from the Chinese Cabbage Brassica campestris L. ssp. pekinensis (Cruciferae). Bull. Chem. Soc. Jpn. 1988, 61, 285-289.

Takahata Y, and Takeda, T. Intergeneric (Intersubtribe) Hybridization between Moricandia arvensis and Brassica A and B Genome Species by Ovary Culture. Theor. Appl. Genet. 1990, $80,38-42$.

Tang, C. and Takenaka, T. Quantitation of a Bioactive Metabolite in Undisturbed Rhizosphere - Benzyl Isothiocyanate from Carica papaya L. J. Chem. Ecol. 1983, 9, 1247-1253.

Tang, J.H., Brown, J., and Davis, J.B. Developing Canola Quality Cultivars in Yellow Mustard (Sinapis alba). In Proc. Pacific Northwest Canola Conference, Coeur d'Alene, Idaho, November 5-7 1995.

Teasdale, J.R. and Taylorson, R.B. Weed Seed Response to Methyl Isothiocyanate and Metham. Weed Sci. 1986, 34, 520-524.

Thangstad, O.P., Iversen, T.-H., Slupphaug, G., and Bones, A. Immunocytochemical Localization of Myrosinase in Brassica napus L. Planta 1990, 180, 245-280.

Thangstad, O.P., Evjen, K., and Bones, A. Immunogold-EM Localization of Myrosinase in Brassicaceae. Protoplasma. 1991, 161, 85-93.

Tiedink, H.G.M., Malingré, C.E., van Broekhoven, L.W., Jongen, W.M.F., Lewis, J., and Fenwick, G.R. Role of Glucosinolates in the Formation of $N$-Nitroso Compounds. J. Agric. Food Chem. 1991, 39, 922-926.

Toba, H.H. Metham-Sodium for Control of Wireworm Larvae. J. Agric. Entomol. 1984, 1, 392-396. 
Tollsten, L. and Bergström, G. Headspace Volatiles of Whole Plants and Macerated Plant Parts of Brassica and Sinapis. Phytochemistry 1988, 27, 2073-2077.

Tommerup, I.C. Development of Infection by a Vesicular-Arbuscular Mycorrhizal Fungus in Brassica napus L. and Trifolium subterraneum L. New Phytol. 1984, 98, 487-495.

Tookey, H.L., Van Etten, C.H., and Daxenbichler, M.E. Glucosinolates. In Toxic Constituents of Plant Foodstuffs. Liener, I.E. Ed.; Academic Press: New York 1980, pp. 103-142.

Toriyama K., Hinata, K. and Kameya, T. Production of Somatic Hybrid Plants, "Brassicomoricandia" through Protoplast Fusion between Moricandia arvensis and Brassica oleracea. Plant Sci. 1987a, 48, 123-128.

Toriyama K., Kameyta, T., and Hinata, K. Selection of a Universal Hybridizer in Sinapis turgida Del. and Regeneration of Plantlets from Somatic Hybrids with Brassica Species. Planta 1987b, 170, 308-313.

Traynier, R.M.M. and Truscott, R.J.W. Potent Natural Egg-Laying Stimulant for Cabbage Butterfly Pieris rapae. J. Chem. Ecol. 1991, 17, 1371-1380.

Truscott, R.J.W., Johnstone, P.K., Minchinton, I.R., and Sang, J.P. Indole Glucosinolates in Swede (Brassica napobrassica L. Mill). J. Agric. Food Chem. 1983, 31, 863-867.

Turner, N.J. and Corden, M.E. Decomposition of Sodium N-Methyldithiocarbamate in Soil. Phytopathology 1963, 53, 1388-1394.

U, N. Genome Analysis in Brassica with Special Reference to the Experimental Formation of B. napus and Peculiar Mode of Fertilization. Jap. J. Bot. 1935, 7, 389-452.

Uda, Y., Kurata, T., and Arakawa, N. Effects of $\mathrm{pH}$ and Ferrous Ion on the Degradation of Glucosinolates by Myrosinase. Agric. Biol. Chem. 1986a, 50, 2735-2740.

Uda, Y., Kurata, T., and Arakawa, N. Effects of Thiol Compounds on the Formation of Nitriles from Glucosinolates. Agric. Biol. Chem. 1986b, 50, 2741-2746.

Uda, Y., Matsuoka, H., Shima, H., Kumagami, H., and Maeda, Y. Antimicrobial Activity of Water-Soluble Products Derived from Radish Mustard Oil and Identification of an Active Component Therein. Nip. Shok. Kogyo Gak. 1993, 40, 801-806.

Uda, Y., Ozawa, Y., Oshima, T., and Kawakishi, S. Identification of Enolated 2-Thioxo-3Pyrrolidinecarbaldehyde, a New Degradation Product of 4-Methylthio-3-butenyl Isothiocyanate. Agric. Biol. Chem. 1990, 54, 613-617.

Underhill, E.W. and Kirkland, D.F. A New Thioglucoside, 2-Methylpropylglucosinolate. Phytochemistry 1972, 11, 2085-2088. 
Underhill, E.W. and Wetter, L.R. Biosynthesis of Mustard Oil Glucosides: Sodium Phenylacetothiohydroximate and Desulfobenzylglucosinolate, Precursors of Benzylglucosinolate in Tropaeolum majus L. Plant Physiol. 1969, 44, 584-590.

Van Den Berg, F., Leistra, M., Roos, A..H., and Tuinstra, L.G.M.Th. Sampling and Analysis of the Soil Fumigants 1,3-Dichloropropene and Methyl Isothiocyanate in the Air. Wat. Air Soil Poll. 1992, 61, 385-396.

Van Etten, C.H., Daxenbichler, M.E., and Wolff, I.A. Natural Glucosinolates (Thioglucosides) in Foods and Feeds. J. Agric. Food Chem. 1969, 17, 483-491.

Van Etten, C.H. and Tookey, H.L. Chemistry and Biological Effects of Glucosinolates. In Herbivores, Their Interaction with Secondary Plant Metabolites, Rosenthal, G.A. and Janzen, D.H., Eds., Academic Press: New York 1979, pp. 471-500.

Van Etten, C.H. and Wolff, I.A. Natural Sulfur Compounds. In Toxicants Occurring Naturally in Foods. National Academy of Sciences: Washington, D.C. 1973, pp. 210-234.

Van Schreven, D.A., Lindenbergh, D.J., and Koridon, A. Effect of Several Herbicides on Bacterial Populations and Activity and the Persistence of These Herbicides in Soil. Plant and Soil 1970, 33, 513-532.

Vaughn, S.F. and Boydston, R.A. Phytotoxicity of Brassica spp. Volatiles to Weed and Crop Seed Germination and Growth. In WSSA Abstracts. Kupatt, C.C. Ed.; Weed Science Society of America: Champaign, IL 1995, p. 55.

Vaughan, J.G. A Multidisciplinary Study of the Taxonomy and Origin of Brassica Crops. BioSci. 1977, 27, 35-40.

Vera, C.L., McGregor, D.I., and Downey, R.K. Detrimental Effects of Volunteer Brassica on Production of Certain Cereal and Oilseed Crops. Can. J. Plant Sci. 1987, 67, 983-995.

Vierheilig, H. and Ocampo, J.A. Effect of Isothiocyanates on Germination of Spores of G. mosseae. Soil Biol. Biochem. 1990, 22, 1161-1162.

Virtanen, A.I. Studies on Organic Sulphur Compounds and Other Labile Substances in Plants. Phytochemistry 1965, 4, 207-228.

Visentin, M., Tava, A., Iori, R., and Palmieri, S. Isolation and Identification of trans-4(Methylthio)-3-Butenyl Glucosinolate from Radish Roots (Raphanus sativus L.). J. Agric. Food Chem. 1992, 40, 1687-1691.

Voet, D. and Voet, J.G. Biochemistry. John Wiley and Sons: New York 1990. 
Von Qualen, R.H., Abney, T.S., Huber, D.M., and Schrieber, M.M. Effects of Rotation, Tillage, and Fumigation on Premature Dying of Soybeans. Plant Disease 1989, 73, 740-744.

Waddington, J. Growth of Barley, Bromegrass, and Alfalfa in the Greenhouse in Soil Containing Rapeseed and Wheat Residues. Can. J. Plant Sci. 1978, 58, 241-248.

Waddington, J. and Bowren, K.E. Effects of Crop Residues on Production of Barley, Bromegrass and Alfalfa in the Greenhouse and of Barley in the Field. Can. J. Plant Sci. 1978, 58, 249-255.

Wadleigh, R.W. and Yu, S.J. Detoxification of Isothiocyanate Allelochemicals by Glutathione Transferase in Three Lepidopterous Species. J. Chem. Ecol. 1988, 14, 1279-1288.

Walker, J.C., Morell, S., and Foster, H.H. Toxicity of Mustard Oils and Related Sulfur Compounds to Certain Fungi. Amer. J. Bot. 1937, 24, 536-541.

Ware, G.W. Pesticides, Theory and Application. Freeman: San Francisco 1983.

Warwick, S.I., and Francis, A. Guide to the Wild Germplasm of Brassica and Allied Crops V. Life History and Geographical Data for Wild Species in the Tribe Brassicaceae (Cruciferae). 1994, Technical Bulletin 1994-2E. Centre for Land and Biological Research, Agriculture Canada.

Wattenberg, L.W. Inhibition of Carcinogenic Effects of Polycyclic Hydrocarbons by Benzyl Isothiocyanate and Related Compounds. J. Natl. Cancer Inst. 1977, 58, 395-398.

Wattenberg, L.W. Inhibition of Carcinogen-Induced Neoplasia by Sodium Cyanate, tertButyl Isocyanate, and Benzyl Isothiocyanate Administered Subsequent to Carcinogen Exposure. Cancer Res. 1981, 41, 2991-2994.

Wetter, L.R. and Dyck, J. Preparation of Highly Purified 3-Butenyl- and 2-Hydroxy-3Butenylglucosinolates. Can. J. Anim. Sci. 1973, 53, 625-626.

Whittaker, R.H. and Feeny, P.P. Allelochemics: Chemical Interactions between Species. Science 1971, 171, 757-770.

Williams, L. III, Morra, M.J., Brown, P.D. and McCaffrey, J.P. Toxicity of Allyl Isothiocyanate-Amended Soil to Limonius californicus (Mann.) (Coleoptera: Elateridae) Wireworms. J. Chem. Ecol. 1993, 19, 1033-1046.

Winkler, H. and Otto, G. Replant Losses with Strawberries and Suggestions for Their Reduction. Hort. Abst. 1980, 50, 344 (4090).

Witczak, Z.J. Monosaccharide Isothiocyanates and Thiocyanates: Synthesis, Chemistry, and Preparative Applications. Adv. Carbohyd. Chem. Biochem. 1986, 44, 91-145. 
Wolf, R.B., Spencer, G.F., and Kwolek, W.F. Inhibition of Velvetleaf (Abutilon theophrasti) Germination and Growth by Benzyl Isothiocyanate, a Natural Toxicant. Weed Sci. 1984, 32, 612-615.

Wood, J.L. Biochemistry. In Chemistry and Biochemistry of Thiocyanic Acid and Its Derivatives; Newman, A.A., Ed., Academic Press: London 1975, pp. 156-221.

Worthing, C.R., (Ed.). The Pesticide Manual. British Crop Protection Council: Thornton Heath, UK 1987.

Wu, Y.F. and Basler, E. Effects of Ammonium Thiocyanate on Carbohydrate Metabolism in the Cotton Plant. Weed Sci. 1969, 17, 362-365.

Xue, J., Pihlgren, U., and Rask, L. Temporal, Cell-Specific, and Tissue-Preferential Expression of Myrosinase Genes during Embryo and Seedling Development in Sinapis alba. Planta 1993, 191, 95-101.

Yamane, A., Fujikura, J., Ogawa, H., and Mizutani, J. Isothiocyanates as Allelopathic Compounds from Rorippa indica Hiern. (Cruciferae) Roots. J. Chem. Ecol. 1992, 18 1941-1954.

Zhang, Y., Kensler, T.W., Cho, C.G., Posner, G.H., and Talalay, P. Anticarcinogenic Activities of Sulforaphane and Structurally Related Synthetic Norbornyl Isothiocyanates. Proc. Natl. Acad. Sci. USA 1994, 91, 3147-3150.

Zhang, Y., Talalay, P., Cho, C.G., and Posner, G.H. A Major Inducer of Anticarcinogenic Protective Enzymes from Broccoli: Isolation and Elucidation of Structure. Proc. Natl. Acad. Sci. USA 1992, 89, 2399-2403.

Zenker, N., Hubbard, L.S., and Wright, J. Inhibition of Dopamine ß-Hydroxylase by Goitrin, a Natural Antithyroid Compound. J. Nat. Prod. 1988, 51, 862-865. 
Table 1. Naturally Occurring Glucosinolates

\begin{tabular}{|c|c|c|c|c|}
\hline$R=$ & trivial name & plant & part $^{a}$ & Reference. \\
\hline methyl $\mathrm{CH}_{3}$ & glucocapparin & $\begin{array}{l}\text { various Capparis } \\
\text { various Cleome }\end{array}$ & $\begin{array}{l}\mathrm{s} \\
\mathrm{s} \\
\mathrm{s}\end{array}$ & $\begin{array}{l}\text { Kjaer and Thomsen 1963a } \\
\text { Kjaer et al. } 1955 \\
\text { Kjaer and Thomsen 1963a }\end{array}$ \\
\hline ethyl $\mathrm{CH}_{3} \mathrm{CH}_{2}$ & glucolepdiin & Lepidium menziesii & $\mathrm{s}$ & Kjaer and Larsen 1954 \\
\hline 2-methylethyl (isopropyl) $\left(\mathrm{CH}_{3}\right)_{2} \mathrm{CH}$ & glucoputranjivin & $\begin{array}{l}\text { Brassica napobrassica } \\
\text { Cochlearia officinalis } \\
\text { Lunaria biennis } \\
\text { Moringa peregrina }\end{array}$ & $\begin{array}{l}r \\
s \\
s\end{array}$ & $\begin{array}{l}\text { Shaw et al. } 1989 \\
\text { Kjaer and Conti } 1953 \\
\text { Kjaer and Conti } 1953 \\
\text { Kjaer et al. } 1979\end{array}$ \\
\hline propyl $\mathrm{CH}_{3} \mathrm{CH}_{2} \mathrm{CH}_{2}$ & & Brassica oleraceae & I & MacLeod and Nussbaum 1977 \\
\hline 1-methylpropyl $\mathrm{CH}_{3} \mathrm{CH}_{2}\left(\mathrm{CH}_{3}\right) \mathrm{CH}$ & glucocochlearin & $\begin{array}{l}\text { Brassica napobrassica } \\
\text { Brassica campestris (B. rapa) } \\
\text { Dentaria pinnata }\end{array}$ & $\begin{array}{l}r \\
\mathrm{I}, \mathrm{r} \\
\mathrm{r}\end{array}$ & $\begin{array}{l}\text { Shaw et al. } 1989 \\
\text { Carlson et al. } 1987 \\
\text { Delaveau and Kjaer } 1963\end{array}$ \\
\hline 2-methylpropyl $\mathrm{CH}_{3}\left(\mathrm{CH}_{3}\right) \mathrm{CHCH}_{2}$ & & $\begin{array}{l}\text { Armoracia lapathifolia } \\
\text { Brassica napus } \\
\text { Conringia orientalis } \\
\text { Moringa peregrina }\end{array}$ & $\begin{array}{l}r \\
r \\
s \\
\text { l } \\
s\end{array}$ & $\begin{array}{l}\text { Grob and Matile } 1980 \\
\text { Gilbert and Nursten } 1972 \\
\text { Brown and Morra } 1995 \\
\text { Underhill and Kirkland } 1972 \\
\text { Kjaer et al. } 1979\end{array}$ \\
\hline butyl $\mathrm{CH}_{3}\left(\mathrm{CH}_{2}\right)_{3}$ & & $\begin{array}{l}\text { Armoracia lapathifolia } \\
\text { Capparis flexuosa }\end{array}$ & $\begin{array}{l}r \\
l\end{array}$ & $\begin{array}{l}\text { Grob and Matile } 1980 \\
\text { Kjaer and Schuster } 1971\end{array}$ \\
\hline 2-methylbutyl $\mathrm{CH}_{3} \mathrm{CH}_{2}\left(\mathrm{CH}_{3}\right) \mathrm{CHCH}_{2}$ & & $\begin{array}{l}\text { Armoracia lapathifolia } \\
\text { Dentaria pinnata }\end{array}$ & $\begin{array}{l}r \\
r\end{array}$ & $\begin{array}{l}\text { Grob and Matile } 1980 \\
\text { Delaveau and Kjaer } 1963\end{array}$ \\
\hline 3-methylbutyl $\mathrm{CH}_{3}\left(\mathrm{CH}_{3}\right) \mathrm{CHCH}_{2} \mathrm{CH}_{2}$ & & Armoracia lapathifolia & r & Grob and Matile 1980 \\
\hline pentyl $\mathrm{CH}_{3}\left(\mathrm{CH}_{2}\right)_{4}$ & & $\begin{array}{l}\text { Armoracia lapathifolia } \\
\text { Brassica rapa }\end{array}$ & $\begin{array}{l}r \\
l\end{array}$ & $\begin{array}{l}\text { Grob and Matile } 1980 \\
\text { Itoh et al. } 1984\end{array}$ \\
\hline
\end{tabular}


4-methylpentyl $\mathrm{CH}_{3}\left(\mathrm{CH}_{3}\right) \mathrm{CH}\left(\mathrm{CH}_{2}\right)_{3}$

hexyl $\mathrm{CH}_{3}\left(\mathrm{CH}_{2}\right)_{5}$

5-methylhexyl $\mathrm{CH}_{3}\left(\mathrm{CH}_{3}\right) \mathrm{CH}\left(\mathrm{CH}_{2}\right)_{4}$

allyl $\mathrm{CH}_{2} \mathrm{CHCH}_{2}$

2-methyl-2-propenyl $\mathrm{CH}_{2}\left(\mathrm{CH}_{3}\right) \mathrm{CCH}_{2}$

3-butenyl $\mathrm{CH}_{2} \mathrm{CHCH}_{2} \mathrm{CH}_{2}$

gluconapin

3-methyl-3-butenyl $\mathrm{CH}_{2}\left(\mathrm{CH}_{3}\right) \mathrm{CCH}_{2} \mathrm{CH}_{2}$
Armoracia lapathifolia

Brassica napus

1996

Raphanus sativus

Brassica napus

Raphanus sativus

Armoracia lapathifolia

Brassica napus

Armoracia lapathifolia

Brassica carinata

\section{Brassica juncea}

Brassica napus

Brassica oleraceae

Peltaria alliacea

Brassica campestris (B. rapa)

Brassica oleraceae

Brassica napus

Brassica napobrassica

Capparis linearis
Grob and Matile 1980

I,s,r Brown and Morra 1995

r $\quad$ Kjaer et al. 1978

s Kondo et al. 1985

r $\quad$ Kjaer et al. 1978

r $\quad$ Grob and Matile 1980

I,s,r $\quad$ Brown and Morra 1996

Grob and Matile 1980

Birch et al. 1992

Shaw et al. 1989

Nastruzzi et al. 1996

Röbbelen and Thies 1980

Hanley et al. 1983

, s, $r \quad$ Sang et al. 1984

Elfakir et al. 1992

Birch et al. 1992

Minchinton et al. 1982

Hill et al. 1987

Josefsson 1967a,b

Daxenbichler et al. 1991

Hanley et al. 1983

Carlson et al. 1987

Shaw et al. 1989

Birch et al. 1992

Minchinton et al. 1982

Elfakir et al. 1992

Koritsas et al. 1989

I, s Sang et al. 1984

$r \quad$ Birch et al. 1992

Shaw et al. 1989

Kjaer and Wagnières 1965 
4-pentenyl $\mathrm{CH}_{2} \mathrm{CH}\left(\mathrm{CH}_{2}\right)_{3}$

glucobrassicanapin

5-hexenyl $\mathrm{CH}_{2} \mathrm{CH}\left(\mathrm{CH}_{2}\right)_{4}$

2-hydroxypropyl $\mathrm{CH}_{3}(\mathrm{OH}) \mathrm{CHCH}_{2}$

3-hydroxypropyl $\mathrm{HOCH}_{2}\left(\mathrm{CH}_{2}\right)_{2}$

3-hydroxybutyl $\mathrm{CH}_{3}(\mathrm{OH}) \mathrm{CH}\left(\mathrm{CH}_{2}\right)_{2}$

4-hydroxybutyl $\mathrm{HOCH}_{2}\left(\mathrm{CH}_{2}\right)_{3}$

2-hydroxypentyl $\mathrm{CH}_{3}\left(\mathrm{CH}_{2}\right)_{2}(\mathrm{OH}) \mathrm{CHCH}_{2}$

1-methyl-2-hydroxyethyl $\mathrm{HOCH}_{2}\left(\mathrm{CH}_{3}\right) \mathrm{CH}$

glucosysimbrin

1-hydroxymethylpropyl $\mathrm{CH}_{3} \mathrm{CH}_{2}\left(\mathrm{OHCH}_{2}\right) \mathrm{CH}$

1-ethyl-2-hydroxyethyl $\mathrm{HOCH}_{2}\left(\mathrm{CH}_{3} \mathrm{CH}_{2}\right) \mathrm{CH}$

glucosisautricin

2-hydroxy-2-methylpropyl $\mathrm{CH}_{3}(\mathrm{OH})\left(\mathrm{CH}_{3}\right) \mathrm{CCH}_{2}$ glucoconringiin

\section{Armoracia lapathifolia}

Brassica campestris (B. rapa)

Brassica oleraceae

Brassica napus

Brassica napobrassica

Armoracia lapathifolia

Brassica napus

Raphanus sativus

Armoracia lapathifolia

Arabidopsis thaliana

Armoracia lapathifolia

Capparis flexuosa

Arabidopsis thaliana

Capparis flexuosa

Armoracia lapathifolia

Coluteocarpus vesicaria

Dentaria laciniata

Euclidium syriacum

Torularia torulosa

Coluteocarpus vesicaria

Cleome diandra

Sisymbrium austriacum

Cochlearia officinalis

Conringia orientalis
Grob and Matile 1980

Gilbert and Nursten 1972

Carlson et al. 1987

Minchinton et al. 1982

Quinsac et al. 1991

Koritsas et al. 1989

Sang et al. 1984

Birch et al. 1992

Shaw et al. 1989

Grob and Matile 1980

Kondo et al. 1985

Kjaer et al. 1978

Grob and Matile 1980

Hogge et al. 1988

Grob and Matile 1980

Kjaer and Schuster 1971

Hogge et al. 1988

Kjaer and Schuster 1971

Grob and Matile 1980

Al-Shehbaz, Al-Shammary 1987

Daxenbichler et al. 1991

Al-Shehbaz, Al-Shammary 1987

Al-Shehbaz, Al-Shammary 1987

Al-Shehbaz, Al-Shammary 1987

Daxenbichler et al. 1991

Kjaer and Christensen 1962a

Challenger 1959

Challenger 1959 


\begin{tabular}{|c|c|c|c|c|}
\hline & & $\begin{array}{l}\text { not spec } \\
\text { Erysimum orientale }\end{array}$ & & $\begin{array}{l}\text { Underhill and Kirkland } 1972 \\
\text { Eagles et al. } 1981 \\
\text { Kjaer } 1960\end{array}$ \\
\hline $\begin{array}{l}\text { 2-hydroxy-2-methylbutyl } \\
\qquad \mathrm{CH}_{3} \mathrm{CH}_{2}(\mathrm{OH})\left(\mathrm{CH}_{3}\right) \mathrm{CCH}_{2}\end{array}$ & glucocleomin & $\begin{array}{l}\text { Cleome spinosa } \\
\text { Dentaria laciniata }\end{array}$ & $\begin{array}{l}\mathrm{s} \\
\mathrm{s}\end{array}$ & $\begin{array}{l}\text { Kjaer and Thomsen } 1962 \\
\text { Daxenbichler et al. } 1991\end{array}$ \\
\hline 4,5,6,7-tetrahydroxydecyl $\mathrm{CH}_{3}\left(\mathrm{CH}_{2}\right)_{2}\left(\mathrm{CH}_{2} \mathrm{OH}\right)_{4}($ & $\left.\mathrm{CH}_{2}\right)_{3}$ & Capparis grandis & $r$ & Gaind et al. 1975 \\
\hline R-2-hydroxy-3-butenyl $\mathrm{CH}_{2} \mathrm{CH}(\mathrm{OH}) \mathrm{CHCH}_{2}$ & $\begin{array}{l}\text { progoitrin } \\
\text { (glucorapiferin) }\end{array}$ & $\begin{array}{l}\text { Brassica campestris (B. rapa) } \\
\text { Brassica napobrassica } \\
\text { Brassica napus }\end{array}$ & $\begin{array}{l}\text { s } \\
\text { I,r } \\
r \\
s \\
\text { I } \\
\text { I, s, r } \\
\text { s } \\
r \\
\text { s } \\
\text { I } \\
r\end{array}$ & $\begin{array}{l}\text { Soluski and Dabrowski } 1984 \\
\text { Carlson et al. } 1987 \\
\text { Shaw et al. } 1989 \\
\text { Quinsac et al. } 1991 \\
\text { Koritsas et al. } 1989 \\
\text { Sang et al. } 1984 \\
\text { Daun } 1986 \\
\text { Birch et al. } 1992 \\
\text { Minchinton et al. } 1982 \\
\text { Shaw et al. } 1989 \\
\text { Birch et al. } 1992\end{array}$ \\
\hline S-2-hydroxy-3-butenyl $\mathrm{CH}_{2} \mathrm{CH}(\mathrm{OH}) \mathrm{CHCH}_{2}$ & epiprogoitrin & $\begin{array}{l}\text { Crambe abyssinica } \\
\text { Brassica napus }\end{array}$ & $\begin{array}{l}\mathrm{s} \\
\mathrm{s} \\
\mathrm{s} \\
\mathrm{s}\end{array}$ & $\begin{array}{l}\text { Hanley et al. } 1983 \\
\text { Wetter and Dyck } 1973 \\
\text { Bartlet et al. } 1994 \\
\text { Daun } 1986\end{array}$ \\
\hline 2-hydroxy-4-pentenyl $\mathrm{CH}_{2} \mathrm{CHCH}_{2}(\mathrm{OH}) \mathrm{CHCH}_{2}$ & gluconapoleiferin & $\begin{array}{l}\text { Brassica napobrassica } \\
\text { Brassica napus } \\
\text { Brassica oleraceae }\end{array}$ & $\begin{array}{l}r \\
s \\
\text { l } \\
l, s, r \\
r \\
r\end{array}$ & $\begin{array}{l}\text { Shaw et al. } 1989 \\
\text { Elfakir et al. } 1992 \\
\text { Koritsas et al. } 1989 \\
\text { Sang et al. } 1984 \\
\text { Birch et al. } 1992 \\
\text { Birch et al. } 1992\end{array}$ \\
\hline 3-hydroxy-4-pentenyl $\mathrm{CH}_{2} \mathrm{CH}(\mathrm{OH}) \mathrm{CHCH}_{2} \mathrm{CH}_{2}$ & & Armoracia lapathifolia & $r$ & Grob and Matile 1980 \\
\hline 4-oxoheptyl $\mathrm{CH}_{3}\left(\mathrm{CH}_{2}\right)_{2} \mathrm{CO}\left(\mathrm{CH}_{2}\right)_{3}$ & glucocapangulin & $\begin{array}{l}\text { Capparis angulata } \\
\text { not spec. }\end{array}$ & $\mathrm{s}$ & $\begin{array}{l}\text { Kjaer and Thomsen 1963a } \\
\text { Ettlinger and Kjaer } 1968\end{array}$ \\
\hline 5-oxoheptyl $\mathrm{CH}_{3} \mathrm{CH}_{2} \mathrm{CO}\left(\mathrm{CH}_{2}\right)_{4}$ & gluconorcappasalin & Capparis salicifolia & $\mathrm{s}$ & Kjaer and Thomsen 1963b \\
\hline
\end{tabular}


5-oxooctyl $\mathrm{CH}_{3}\left(\mathrm{CH}_{2}\right)_{2} \mathrm{CO}\left(\mathrm{CH}_{2}\right)_{4}$

3-methoxycarbonylpropyl $\mathrm{CH}_{3} \mathrm{OCO}\left(\mathrm{CH}_{2}\right)_{3}$

2-methylthioethyl $\mathrm{CH}_{3} \mathrm{~S}\left(\mathrm{CH}_{2}\right)_{2}$

3-methylthiopropyl $\mathrm{CH}_{3} \mathrm{~S}\left(\mathrm{CH}_{2}\right)_{3}$

4-methylthiobutyl $\mathrm{CH}_{3} \mathrm{~S}\left(\mathrm{CH}_{2}\right)_{4}$

5-methylthiopentyl $\mathrm{CH}_{3} \mathrm{~S}\left(\mathrm{CH}_{2}\right)_{5}$

6-methylthiohexyl $\mathrm{CH}_{3} \mathrm{~S}\left(\mathrm{CH}_{2}\right)_{6}$

7-methylthioheptyl $\mathrm{CH}_{3} \mathrm{~S}\left(\mathrm{CH}_{2}\right)_{7}$

8-methylthiooctyl $\mathrm{CH}_{3} \mathrm{~S}\left(\mathrm{CH}_{2}\right)_{8}$ glucoibervirin

glucoerucin

glucoberteroin

glucolesquerellin
Erysimum aucherianum Erysimum filifolium

Erysimum rupestre

Armoracia lapathifolia (Cochlearia armoracia)

Arabidopsis thaliana

Brassica napus

Brassica oleraceae

Arabidopsis thaliana Brassica campestris (B. rapa) Brassica napus

\section{Brassica oleraceae}

\section{Eruca sativa}

Raphanus sativus Sinapis alba (B. hirta)

\section{Arabidopsis thaliana} Brassica naporbrassica Brassica campestris (B. rapa) Raphanus sativus

\section{Arabidopsis thaliana} Ochthodium aegyptiacumr

\section{Arabis laxa}

Arabidopsis thaliana

Arabidopsis thaliana
Kjaer and Thomsen 1963a

Al-Shehbaz, Al-Shammary 1987

Al-Shehbaz, Al-Shammary 1987

Kjaer 1960

Chisholm 1973

Grob and Matile 1980

Hogge et al. 1988

Minchinton et al. 1982

Minchinton et al. 1982

Shaw et al. 1989

Hogge et al. 1988

Carlson et al. 1987

Sang et al. 1984

Birch et al. 1992

Minchinton et al. 1982

Birch et al. 1992

Kjaer and Gmelin 1955

Nastruzzi et al. 1996

Kjaer et al. 1978

Brown and Morra, unp.

Hogge et al. 1988

Shaw et al. 1989

Carlson et al. 1987

Kjaer et al. 1978

Hogge et al. 1988

Al-Shehbaz, Al-Shammary 1987

Al-Shehbaz, Al-Shammary 1987

Hogge et al. 1988

Hogge et al. 1988 
9-methylthiononyl $\mathrm{CH}_{3} \mathrm{~S}\left(\mathrm{CH}_{2}\right)_{9}$

10-methylthiodecyl $\mathrm{CH}_{3} \mathrm{~S}\left(\mathrm{CH}_{2}\right)_{10}$

4-methylthio-3-butenyl $\mathrm{CH}_{3} \mathrm{SCHCH}\left(\mathrm{CH}_{2}\right)_{2} \quad$ glucodehydroerucin

3-hydroxy-5-methylthiopentyl $\mathrm{CH}_{3} \mathrm{~S}\left(\mathrm{CH}_{2}\right)_{2}(\mathrm{OH}) \mathrm{CH}\left(\mathrm{CH}_{2}\right)_{2}$

3-hydroxy-6-methylthiohexyl $\mathrm{CH}_{3} \mathrm{~S}\left(\mathrm{CH}_{2}\right)_{3}(\mathrm{OH}) \mathrm{CH}\left(\mathrm{CH}_{2}\right)_{2}$

3-oxo-8-methylthiooctyl $\mathrm{CH}_{3} \mathrm{~S}\left(\mathrm{CH}_{2}\right)_{5} \mathrm{CO}\left(\mathrm{CH}_{2}\right)_{2}$

3-methylsulfinylpropyl $\mathrm{CH}_{3} \mathrm{SO}\left(\mathrm{CH}_{2}\right)_{3}$

4-methylsulfinylbutyl $\mathrm{CH}_{3} \mathrm{SO}\left(\mathrm{CH}_{2}\right)_{4}$

5-methylsulfinylpentyl $\mathrm{CH}_{3} \mathrm{SO}\left(\mathrm{CH}_{2}\right)_{5}$

6-methylsulfinylhexyl $\mathrm{CH}_{3} \mathrm{SO}\left(\mathrm{CH}_{2}\right)_{6}$

7-methylsulfinylheptyl $\mathrm{CH}_{3} \mathrm{SO}\left(\mathrm{CH}_{2}\right)_{7}$

8-methylsulfinyloctyl $\mathrm{CH}_{3} \mathrm{SO}\left(\mathrm{CH}_{2}\right)_{8}$ glucoiberin

Arabis hirsuta

Arabis amplexicaulis

Raphanus sativus

$r$

Erysimum hieracifolium Armoracia lapathifolia

Erysimum rhaeticum

Arabis hirsuta

Arabidopsis thaliana

Brassica napus

Brassica oleracea

glucoraphanin (sulphoraphane)

glucoalyssin

glucohesperin

glucosiberin

glucohirsutin
Arabidopsis thaliana

Brassica napus

Brassica oleracea

Alyssum argenteum Arabidopsis thaliana Berteroa incana

Arabidopsis thaliana Euclidium syriacum Notoceras bicorne

Arabis laxa Arabidopsis thaliana

Aethionema arabicum Arabidopsis thaliana
Daxenbichler et al. 1991

Daxenbichler et al. 1991

Daxenbichler et al. 1991

Visentin et al. 1992

Kjaer and Schuster 1970

Grob and Matile 1980

Kjaer and Schuster 1973

Kjaer and Schuster 1972

Hogge et al. 1988

Daun 1986

Birch et al. 1992

Hansen et al. 1995

Hogge et al. 1988

Daun 1986

Hansen et al. 1995

Hill et al. 1987

Kjaer and Gmelin 1956

Hogge et al. 1988

Kjaer and Gmelin 1956

Hogge et al. 1988

Al-Shehbaz, Al-Shammary 1987

Al-Shehbaz, Al-Shammary 1987

Al-Shehbaz, Al-Shammary 1987

Hogge et al. 1988

$\mathrm{S}$

Al-Shehbaz, Al-Shammary 1987

Hogge et al. 1988 
9-methylsulfinylnonyl $\mathrm{CH}_{3} \mathrm{SO}\left(\mathrm{CH}_{2}\right)_{9}$

10-methylsulfinyldecyl $\mathrm{CH}_{3} \mathrm{SO}\left(\mathrm{CH}_{2}\right)_{10}$

glucocamelinin

11-methylsulfinylundecyl $\mathrm{CH}_{3} \mathrm{SO}\left(\mathrm{CH}_{2}\right)_{11}$

4-methylsulfinyl-3-butenyl $\mathrm{CH}_{3} \mathrm{SOCHCH}\left(\mathrm{CH}_{2}\right)_{2}$ glucoraphenin

3-hydroxy-5-methylsulfinylpentyl $\mathrm{CH}_{3} \mathrm{SO}\left(\mathrm{CH}_{2}\right)_{2}(\mathrm{OH}) \mathrm{CH}\left(\mathrm{CH}_{2}\right)_{2}$

3-hydroxy-6-methylsulfinylhexyl $\mathrm{CH}_{3} \mathrm{SO}\left(\mathrm{CH}_{2}\right)_{3}(\mathrm{OH}) \mathrm{CH}\left(\mathrm{CH}_{2}\right)_{2}$

3-oxo-8-methylsulfinyloctyl $\mathrm{CH}_{3} \mathrm{SO}\left(\mathrm{CH}_{2}\right)_{5} \mathrm{CO}\left(\mathrm{CH}_{2}\right)_{2}$

3-methylsulfonylpropyl $\mathrm{CH}_{3} \mathrm{SO}_{2}\left(\mathrm{CH}_{2}\right)_{3}$

glucocheirolin

4-methylsulfonylbutyl $\mathrm{CH}_{3} \mathrm{SO}_{2}\left(\mathrm{CH}_{2}\right)_{4}$

glucoerysolin

6-methylsulfonylhexyl $\mathrm{CH}_{3} \mathrm{SO}_{2}\left(\mathrm{CH}_{2}\right)_{6}$

8-methylsulfonyloctyl $\mathrm{CH}_{3} \mathrm{SO}_{2}\left(\mathrm{CH}_{2}\right)_{8}$

9-methylsulfonylnonyl $\mathrm{CH}_{3} \mathrm{SO}_{2}\left(\mathrm{CH}_{2}\right)_{9}$

10-methylsulfonyldecyl $\mathrm{CH}_{3} \mathrm{SO}_{2}\left(\mathrm{CH}_{2}\right)_{10}$

4-methylsulphonyl-3-butenyl $\mathrm{CH}_{3} \mathrm{SO}_{2} \mathrm{CHCH}\left(\mathrm{CH}_{2}\right)_{2}$
Arabis alpina

Arabis nova

Drabopsis nuda

various Camelina

Camelina microcarpa

Brassica napus

Raphanus sativus

Erysimum hieracifolium ${ }^{\mathrm{b}}$

Erysimum rhaeticum

Arabis hirsuta

Brassica oleraceae

Cheiranthus cheiri

Cheiranthus cheiri

Erysimum perofskianum not spec

\section{Euclidium syriacum}

Heliophila amplexicaulis

Arabis turrita

Heliophila amplexicaulis

Arabis turrita

Raphanus sativus
Challenger 1959

Al-Shehbaz, Al-Shammary 1987

Al-Shehbaz, Al-Shammary 1987

Kjaer et al. 1956b

Daxenbichler et al. 1991

Daun 1986

Birch et al. 1992

Sang et al. 1984

Nastruzzi et al. 1996

Kjaer and Schuster 1970

Kjaer and Schuster 1973

Kjaer and Schuster 1972

Shaw et al. 1989

Challenger 1959

Nastruzzi et al. 1996

Challenger 1959

Kjaer and Conti 1954

Eagles et al. 1981

Al-Shehbaz, Al-Shammary 1987

Daxenbichler et al. 1991

Daxenbichler et al. 1991

Daxenbichler et al. 1991

Daxenbichler et al. 1991

Cole 1980 
3-hydroxy-5-methylsulfonylpentyl $\mathrm{CH}_{3} \mathrm{SO}_{2}\left(\mathrm{CH}_{2}\right)_{2}(\mathrm{OH}) \mathrm{CH}\left(\mathrm{CH}_{2}\right)_{2}$

6-methylsulfonyl-3-hydroxyhexyl $\mathrm{CH}_{3} \mathrm{SO}_{2}\left(\mathrm{CH}_{2}\right)_{3}(\mathrm{OH}) \mathrm{CH}\left(\mathrm{CH}_{2}\right)_{2}$

Benzyl $\mathrm{C}_{6} \mathrm{H}_{5} \mathrm{CH}_{2}$

glucotropaeolin

2-hydroxybenzyl 2- $\mathrm{OHC}_{6} \mathrm{H}_{5} \mathrm{CH}_{2}{ }^{\mathrm{c}}$

3-hydroxybenzyl 3-OHC ${ }_{6} \mathrm{H}_{5} \mathrm{CH}_{2}$

glucolepigramin

4-hydroxybenzyl 4- $\mathrm{OHC}_{6} \mathrm{H}_{5} \mathrm{CH}_{2}$

glucosinalbin

glucoaubrietin

4-methoxybenzyl 4- $\mathrm{CH}_{3} \mathrm{OC}_{6} \mathrm{H}_{5} \mathrm{CH}_{2}$

3,4-dimethoxybenzyl 3,4- $\left(\mathrm{CH}_{3} \mathrm{O}\right)_{2} \mathrm{C}_{6} \mathrm{H}_{5} \mathrm{CH}_{2}$

3,4,5-trimethoxybenzyl 3,4,5- $\left(\mathrm{CH}_{3} \mathrm{O}\right)_{3} \mathrm{C}_{6} \mathrm{H}_{5} \mathrm{CH}_{2}$

2-benzoyloxyethyl $\mathrm{C}_{6} \mathrm{H}_{5} \mathrm{COO}\left(\mathrm{CH}_{2}\right)_{2}$

3,4-dihydroxybenzyl $3,4(\mathrm{OH})_{2} \mathrm{C}_{6} \mathrm{H}_{5} \mathrm{CH}_{2}$

3-methoxybenzyl 3- $\mathrm{CH}_{3} \mathrm{OC}_{6} \mathrm{H}_{5} \mathrm{CH}_{2}$
Erysimum hieracifolium ${ }^{\mathrm{b}}$

Erysimum rhaeticum

Carica papaya

Lepidium sativum

Reseda media

Sinapis alba (B. hirta)

Tropaeolum majus

Reseda odorata

Lepidium vesicarium

Reseda media

Brassica napus

Sinapis alba (B. hirta)

Sinapis arvensis

imnanthe

not spec.

Aubrietia hybrida

Heliophila longifolia

Coronopus squamatus

Moricandia arvensis
S

Kjaer and Schuster 1970

Kjaer and Schuster 1973

Hanley et al. 1983

Hanley et al. 1983

Hasapis and MacLeod 1982

Olsen and Sørenson 1980

Brown and Morra, unp

Cole 1976

s,I Lykkesfeldt and Møller 1993

I Underhill and Wetter 1969

Olsen and Sørensen 1979

Daxenbichler et al. 1991

s,I Olsen and Sørenson 1980

Quinsac et al. 1991

Elfakir et al. 1992

Minchinton et al. 1982

Nastruzzi et al. 1996

Brown and Morra, unp

Al-Shehbaz, Al-Shammary 1987

Kjaer and Larsen 1973

Kjaer 1960

Ettlinger and Kjaer 1968

I,S Kjaer et al. 1956a

s

Daxenbichler et al. 1991

S

Daxenbichler et al. 1991

S

Daxenbichler et al. 1991 
1-methyl-2-benzoyloxyethyl $\mathrm{C}_{6} \mathrm{H}_{5} \mathrm{COOCH}_{2}\left(\mathrm{CH}_{3}\right) \mathrm{CH}_{2}$

1-ethyl-2-benzoyloxyethyl $\mathrm{C}_{6} \mathrm{H}_{5} \mathrm{COOCH}_{2}\left(\mathrm{CH}_{3} \mathrm{CH}_{2}\right) \mathrm{CH}_{2}$

3-benzoyloxypropyl $\mathrm{C}_{6} \mathrm{H}_{5} \mathrm{COO}\left(\mathrm{CH}_{2}\right)_{3}$

4-benzoyloxybutyl $\mathrm{C}_{6} \mathrm{H}_{5} \mathrm{COO}\left(\mathrm{CH}_{2}\right)_{4}$

5-benzoyloxypentyl $\mathrm{C}_{6} \mathrm{H}_{5} \mathrm{COO}\left(\mathrm{CH}_{2}\right)_{5}$

6-benzoyloxyhexyl $\mathrm{C}_{6} \mathrm{H}_{5} \mathrm{COO}\left(\mathrm{CH}_{2}\right)_{6}$

2-(L-rhamnopyranosyloxy)benzyl 2-[(OH $\left.)_{3} \mathrm{C}_{6} \mathrm{H}_{8} \mathrm{O}\right] \mathrm{OC}_{6} \mathrm{H}_{4} \mathrm{CH}_{2}$

4-(L-rhamnopyranosyloxy)benzyl 4-[(OH) $\left.)_{3} \mathrm{C}_{6} \mathrm{H}_{8} \mathrm{O}\right] \mathrm{OC}_{6} \mathrm{H}_{4} \mathrm{CH}_{2}$

4-(4'-O-acetyl-L-rhamnosyloxy)benzyl

$$
4-\left[\left(4^{\prime}-\mathrm{CH}_{3} \mathrm{CO}\right)(\mathrm{OH})_{2} \mathrm{C}_{6} \mathrm{H}_{8} \mathrm{O}\right] \mathrm{OC}_{6} \mathrm{H}_{4} \mathrm{CH}_{2}
$$

2-phenylethyl $\mathrm{C}_{6} \mathrm{H}_{5}\left(\mathrm{CH}_{2}\right)_{2}$

gluconasturtiin

3-phenylpropyl $\mathrm{C}_{6} \mathrm{H}_{5}\left(\mathrm{CH}_{2}\right)_{3}$

glucobenzosisymbrin

glucobenzsisaustricin

glucomalcomiin
Sisymbrium austriacum

$\mathrm{S}$

Sisymbrium austriacum

S

Arabidopsis thaliana

Malcolmis maritima

not spec.

Arabidopsis thaliana

Arabidopsis thaliana

Arabidopsis thaliana

Reseda odorata

Thlaspi perfoliatum

Moringa peregrina

Armoracia lapathifolia

Brassica campestris (B. rapa)

Brassica juncea

Brassica oleraceae

Brassica napobrassica

Brassica napus

Reseda media

Sinapis alba (B. hirta)

Armoracia lapathifolia

S
Daxenbichler et al. 1991

Kjaer and Christensen 1962b

I,S Hogge et al. 1988

s Kjaer 1960

Challenger 1959

I,s Hogge et al. 1988

s $\quad$ Eagles et al. 1981

I,S Hogge et al. 1988

I,s Hogge et al. 1988

Olsen and Sorensen 1979 Al-Shehbaz, Al-Shammary 1987

Kjaer et al. 1979

Grob and Matile 1980

Gilbert and Nursten 1972

Carlson et al. 1987

I, s, r Sang et al. 1984

Minchinton et al. 1982

Birch et al. 1992

Shaw,et al. 1989

Elfakir et al. 1992

Koritsas et al. 1989

s, $r \quad$ Sang et al. 1984

$r \quad$ Birch et al. 1992

s,I Olsen and Sørenson 1980

$r \quad$ Brown and Morra, unp.

Grob and Matile 1980 
Armoracia lapathifolia

Barbaria vulgaris

glucobarbarin

Arabis hirsuta

2-(4-methoxyphenyl)-2-hydroxyethyl $\left[4-\mathrm{CH}_{3} \mathrm{OC}_{6} \mathrm{H}_{4}\right](\mathrm{OH}) \mathrm{CHCH}_{2}$

2,2-dimethyl-2-(4-methoxyphenyl)ethyl $\left[4-\mathrm{CH}_{3} \mathrm{OC}_{6} \mathrm{H}_{4}\right]\left(\mathrm{CH}_{3}\right)_{2} \mathrm{CCH}_{2}$

2-(L-arabinopyranosyloxy)-2-phenylethyl $\mathrm{C}_{6} \mathrm{H}_{5}\left[(\mathrm{OH})_{3} \mathrm{C}_{5} \mathrm{H}_{6} \mathrm{O}\right] \mathrm{CHCH}_{2}$

3-indolylmethyl $\mathrm{C}_{8} \mathrm{H}_{6} \mathrm{NCH}_{2}$

4-hydroxy-3-indolylmethyl $4-\mathrm{OHC}_{8} \mathrm{H}_{5} \mathrm{NCH}_{2}$

1-methoxy-3-indolylmethyl

1- $\left(\mathrm{CH}_{3} \mathrm{O}\right) \mathrm{C}_{8} \mathrm{H}_{5} \mathrm{NCH}_{2}$ 4-hydroxyglucobrassicin

neoglucobrassicin
Brassica campestris (B. rapa)

Brassica napobrassica

Brassica napus

Brassica oleraceae

Camelina alyssum

Lepidium graminifolium

Raphanus sativus

\section{Brassica napobrassica \\ Brassica napus}

Brassica oleraceae

Brassica campestris (B. rapa)

Brassica napobrassica

Brassica napus glucobrassicin
Daxenbichler et al. 1991

Ettlinger and Kjaer 1968

Daxenbichler et al. 1991

Kjaer and Schuster 1972

Migirab et al. 1977

Olsen et al. 1981

Sosulski and Dabrowski 1984

Carlson et al. 1987

Hansen et al. 1995

Shaw et al. 1989

Quinsac et al. 1991

Macfarlane-Smith et al. 1991

s, $r \quad$ Sang et al. 1984

Birch et al. 1992

Hanley et al. 1983

Birch et al. 1992

Bäuerle et al. 1986

Bäuerle et al. 1986

Sang et al. 1984

Shaw et al. 1989

Quinsac, et al. 1991

, s, r Sang etal. 1984

Birch et al. 1992

Shaw et al. 1989

Birch et al. 1992

Sosulski and Dabrowski 1984

Truscott et al. 1983

Macfarlane-Smith et al. 1991 
Brassica oleraceae

Cochlearia officianalis

4-methoxy-3-indolylmethy

4- $\left(\mathrm{CH}_{3} \mathrm{O}\right) \mathrm{C}_{8} \mathrm{H}_{5} \mathrm{NCH}_{2}$

1-acetyl-3-indolylmethyl 1-( $\left.\mathrm{CH}_{3} \mathrm{CO}\right) \mathrm{C}_{8} \mathrm{H}_{5} \mathrm{NCH}_{2}$

1-sulphonate-3-indolylmethyl 1- $\left(\mathrm{OSO}_{3}\right) \mathrm{C}_{8} \mathrm{H}_{5} \mathrm{NCH}_{2}$

4-methoxyglucobrassicin

\section{Brassica napus}

Brassica oleraceae

Lepidium sativum

Tovaria pendula

glucobrassicin-1-sulfonate Isatis tinctoria
Elfakir et al. 1992

Sang et al. 1984

Birch et al. 1992

Hanley et al. 1983

Birch et al. 1992

Bäuerle et al. 1986

Shaw et al. 1989

Koritsas et al. 1989

Sang et al. 1984

Birch et al. 1992

Shaw et al. 1989

Birch et al. 1992

Bäuerle et al. 1986

Schraudolf and Bauerle 1986

Elliott and Stowe 1970

${ }^{a} \mathrm{~s}=$ seed, young seedling, or inflorescence, I = leaf and/or stem, $r=$ root, ${ }^{b}$ identification changed to E. virgatum Roth (Kjaer and Schuster 1973), ${ }^{c}$ tentative identification. 
Table 2. Effects of Aqueous Extracts from Glucosinolate-Containing Tissues on Other Plants

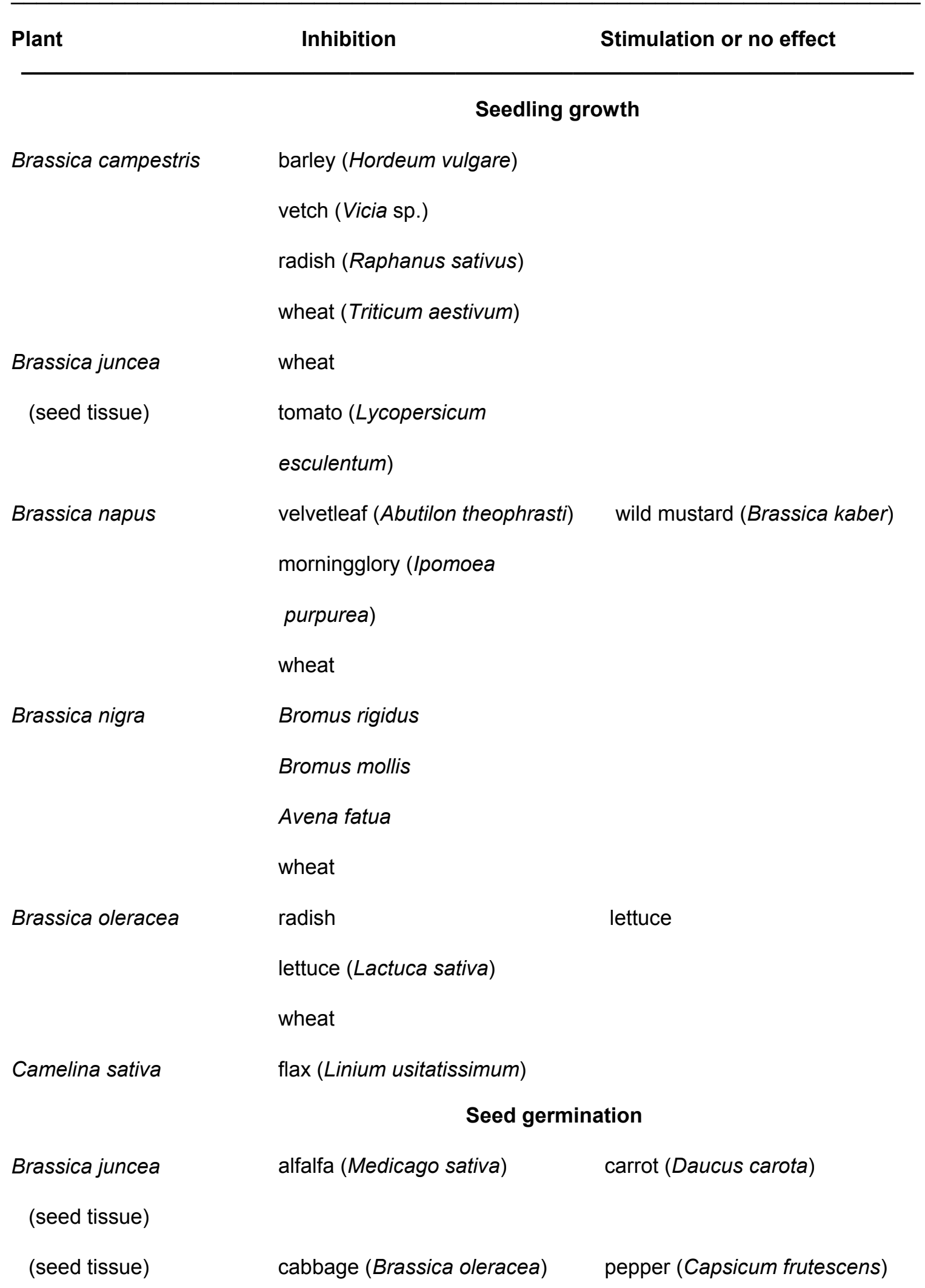




$\begin{array}{cll}\text { (seed tissue) } & \text { radish } & \text { timothy (Phleum pratense) } \\ \text { (seed tissue) } & \text { turnip (Brassica rapa) } & \text { tomato } \\ \text { Brassica oleracea } & \text { wheat } & \end{array}$

References: Mason-Sedun and Jessop 1988; Jimenez-Orsornio and Gleissman 1987; MasonSedun et al. 1986; Leather 1983; Bell and Muller 1973; Kutacek 1964; Gressel and Holm 1964; Patrick et al. 1963; Grummer and Beyer 1960. 
Table 3. Influence of Naturally Occurring Isothiocyanates on Microorganisms

\begin{tabular}{|c|c|c|c|}
\hline \multirow[t]{2}{*}{ Organism $^{a}$} & \multicolumn{2}{|c|}{ Concentration } & \multirow[t]{2}{*}{ Evaluation criterion } \\
\hline & $\mu \mathrm{g} \mathrm{mL}^{-1}$ & {$[\mathrm{M}]$} & \\
\hline & \multicolumn{2}{|c|}{ Methyl ITC } & \\
\hline \multirow[t]{2}{*}{ P. petersonii } & 20 & $27 \times 10^{-5}$ & inhib. growth \& prod. \\
\hline & 100 & $68 \times 10^{-5}$ & biomass reduced $93 \%$ \\
\hline \multirow[t]{2}{*}{ P. shermanii } & 10 & $14 \times 10^{-5}$ & inhib. growth \& prod. \\
\hline & 100 & $68 \times 10^{-5}$ & biomass reduced $90 \%$ \\
\hline S. aureus & 11 & $15 \times 10^{-5}$ & minimum for inhibition \\
\hline A. eutiches & 0.1 & $14 \times 10^{-7}$ & no zoospore formation \\
\hline \multirow[t]{3}{*}{ A. niger } & 23 & $31 \times 10^{-5}$ & $50 \%$ growth inhibition $4 d$ \\
\hline & 50 & $68 \times 10^{-5}$ & $100 \%$ growth inhibition $4 d$ \\
\hline & 110 & $15 \times 10^{-4}$ & $100 \%$ growth inhibition $>14 d$ \\
\hline C. circinans & 40 & $55 \times 10^{-5}$ & $100 \%$ growth inhibition \\
\hline G. graminis & 0.1 & $10 \times 10^{-7}$ & minimum for inhibition in $\mathrm{hs}^{\mathrm{b}}$ \\
\hline M. sitophila & $<7$ & $<10 \times 10^{-5}$ & $100 \%$ growth inhibition \\
\hline P. glaucum & 2 & $27 \times 10^{-6}$ & minimum for inhibition \\
\hline \multirow[t]{3}{*}{ P. cyclopium } & 14 & $19 \times 10^{-5}$ & $50 \%$ growth inhibition $6 \mathrm{~d}$ \\
\hline & 37 & $51 \times 10^{-5}$ & $100 \%$ growth inhibition $6 \mathrm{~d}$ \\
\hline & 110 & $15 \times 10^{-4}$ & $100 \%$ growth inhibition $>14 d$ \\
\hline \multirow[t]{3}{*}{ R. oryzae } & 11 & $15 \times 10^{-5}$ & $50 \%$ growth inhibition $6 \mathrm{~d}$ \\
\hline & 17 & $23 \times 10^{-5}$ & $100 \%$ growth inhibition $6 \mathrm{~d}$ \\
\hline & 28 & $38 \times 10^{-5}$ & $100 \%$ growth inhibition $>14 d$ \\
\hline
\end{tabular}




\section{Ethyl ITC}
A. niger
$1720 \times 10^{-5} \quad 50 \%$ growth inhibition $4 d$
C. circinans
$122 \quad 14 \times 10^{-4} \quad 100 \%$ growth inhibition $4 d$
P. cyclopium
$40 \quad 46 \times 10^{-5} \quad$ no effect
R. oryzae
$>261 \quad>30 \times 10^{-4} \quad 100 \%$ growth inhibition $14 d$
$26130 \times 10^{-4} \quad 100 \%$ growth inhibition $>14 d$

Allyl ITC

B. subtilis IFO-13722

$0.11 \quad 11 \times 10^{-7} \quad 100 \%$ growth inhibition ${ }^{b}$

B. cereus IFO-13494

$0.0991 \times 10^{-8} \quad 100 \%$ growth inhibition ${ }^{b}$

E. coli

$36 \quad 36 \times 10^{-5} \quad$ delay growth $36 \mathrm{~h}^{\mathrm{c}}$

E. coli JCM-1649

$P$. aeruginosa

$0.03434 \times 10^{-8} \quad 100 \%$ growth inhibition ${ }^{\mathrm{b}}$

P. fragi

$27 \quad 27 \times 10^{-5} \quad$ delay growth $45 \mathrm{~h}$

P. vulgaris

$16 \quad 16 \times 10^{-5} \quad$ delay growth $40 \mathrm{~h}$

$36 \quad 36 \times 10^{-5} \quad$ delay growth $60 \mathrm{~h}$

S. enteritidis JCM-1891

S. aureus

$0.11 \quad 11 \times 10^{-7} \quad 100 \%$ growth inhibition ${ }^{b}$

$110 \times 10^{-6} \quad$ minimum for inhibition

$36 \quad 36 \times 10^{-5} \quad$ delay growth $33 \mathrm{~h}$

$0.11 \quad 11 \times 10^{-7} \quad 100 \%$ growth inhbition ${ }^{b}$

A. alliaceus

$61 \times 10^{-5} \quad$ biomass reduced $98 \%$

$5 \quad 51 \times 10^{-6} \quad 100 \%$ growth inhibition

A. eutiches

$0.1 \quad 10 \times 10^{-7} \quad$ no zoospore formation

A. niger

$6 \quad 60 \times 10^{-6} \quad 50 \%$ growth inhibition $4 d$

$65 \quad 66 \times 10^{-5} \quad 100 \%$ growth inhibition $4 d$

$5 \quad 51 \times 10^{-6} \quad 100 \%$ growth inhibition

$60 \quad 61 \times 10^{-5} \quad$ biomass reduced $60 \%$

B. allii

$40 \quad 40 \times 10^{-5} \quad 100 \%$ growth inhibition 

B. cinerea
C. circinans
Cytospora sp.
Fusarium sp.
F. oxysporum NFRI-1011
F. solani IFO-9425
G. graminis
G. saubinetti

M. laxa

M. sitophila

M. piriformis

P. chrysogenum IFO-6223

P. cyclopium

P. expansum

P. gluacum

R. oryzae

R. stolonifer

\begin{tabular}{|c|c|c|}
\hline 600 & $61 \times 10^{-4}$ & minimum for inhibition of germ. \\
\hline 5 & $51 \times 10^{-6}$ & $100 \%$ growth inhibition \\
\hline$>99$ & $>10 \times 10^{-4}$ & $100 \%$ inhibition of germ \\
\hline$>99$ & $>10 \times 10^{-4}$ & $100 \%$ growth inhibition \\
\hline 0.022 & $22 \times 10^{-8}$ & $100 \%$ growth inhibition ${ }^{b}$ \\
\hline 0.034 & $34 \times 10^{-8}$ & $100 \%$ growth inhibition $^{\mathrm{b}}$ \\
\hline 0.1 & $10 \times 10^{-7}$ & min. for inhibition in hs \\
\hline 15 & $15 \times 10^{-5}$ & $100 \%$ growth inhibition \\
\hline 1 & $10 \times 10^{-6}$ & $100 \%$ growth inhibition \\
\hline 300 & $30 \times 10^{-4}$ & min. for inhibition of germ. \\
\hline$<10$ & $<10 \times 10^{-5}$ & $100 \%$ growth inhibition \\
\hline 150 & $15 \times 10^{-4}$ & minimum for inhibition of germ. \\
\hline 0.062 & $63 \times 10^{-8}$ & $100 \%$ growth inhibiton $^{\mathrm{b}}$ \\
\hline 9 & $90 \times 10^{-6}$ & $50 \%$ growth inhibition $6 \mathrm{~d}$ \\
\hline 22 & $22 \times 10^{-5}$ & $100 \%$ growth inhibition $6 \mathrm{~d}$ \\
\hline 151 & $15 \times 10^{-4}$ & $100 \%$ growth inhibition $>14 d$ \\
\hline 600 & $61 \times 10^{-4}$ & minimum for inhibition of germ. \\
\hline 9 & $91 \times 10^{-6}$ & minimum for inhibition \\
\hline 10 & $10 \times 10^{-5}$ & $50 \%$ growth inhibition $6 \mathrm{~d}$ \\
\hline 74 & $75 \times 10^{-5}$ & $100 \%$ growth inhibition $6 \mathrm{~d}$ \\
\hline 600 & $61 \times 10^{-4}$ & minimum for inhibition of germ. \\
\hline
\end{tabular}

\section{5-Methylthiopentyl ITC}

S. aureus
A. niger

17

$\begin{array}{lll}35 & 20 \times 10^{-5} & 100 \% \text { growth inhibition } 4 d \\ 66 & 38 \times 10^{-5} & 100 \% \text { growth inhibition }>14 d\end{array}$



P. cyclopium
$23 \quad 13 \times 10^{-5} \quad 50 \%$ growth inhibition $6 \mathrm{~d}$
$3319 \times 10^{-5} \quad 100 \%$ growth inhibition $6 \mathrm{~d}$
$66 \quad 38 \times 10^{-5} \quad 100 \%$ growth inhibition $>14 d$
P. gluacum
$31 \quad 18 \times 10^{-5} \quad$ minimum for inhibition

\section{4-Methylsulfinyl-3-butenyl ITC}
B. cinerea
M. laxa
M. piriformis
P. expansum
R. stolonifer

E. coli

P. vulgaris

S. Iutealis

S. aureus

A. eutiches

A. niger

Cytospora sp.

Fusarium sp.

M. sitophila

P. cyclopium

P. gluacum

$\begin{array}{rll}230 & 13 \times 10^{-4} & \text { minimum for inhibition of germ. } \\ 20 & 11 \times 10^{-5} & \text { minimum for inhibition of germ. } \\ 460 & 26 \times 10^{-4} & \text { minimum for inhibition of germ. } \\ 930 & 53 \times 10^{-4} & \text { minimum for inhibition of germ. } \\ 290 & 17 \times 10^{-4} & \text { minimum for inhibition of germ. }\end{array}$

\section{Benzyl ITC}

$321 \times 10^{-6} \quad$ minimum for inhibition

$642 \times 10^{-6} \quad$ minimum for inhibition

$1.510 \times 10^{-6} \quad$ minimum for inhibition

$213 \times 10^{-6} \quad$ minimum for inhibition

$167 \times 10^{-7} \quad$ no zoospore formation

$216 \times 10^{-6} \quad 50 \%$ growth inhibition $4 \mathrm{~d}$

$27 \quad 18 \times 10^{-5} \quad 100 \%$ growth inhibition $4 d$

$57 \quad 38 \times 10^{-5} \quad 100 \%$ growth inhibition $>14 d$

$<75 \quad<50 \times 10^{-5} \quad 100 \%$ growth inhibition

$<1.5<10 \times 10^{-6} \quad 100 \%$ growth inhibition

$<1.5<10 \times 10^{-6} \quad 100 \%$ growth inhibition

$640 \times 10^{-6} \quad 50 \%$ growth inhibition $6 \mathrm{~d}$

$30 \quad 20 \times 10^{-5} \quad 100 \%$ growth inhibition $6 \mathrm{~d}$

$57 \quad 38 \times 10^{-5} \quad 100 \%$ growth inhibition $>14 d$

$213 \times 10^{-6} \quad$ minimum for inhibition 
P. palmivora

R. oryzae

S. aureus

A. alliaceus

A. eutiches

A. niger

C. circinans

Fusarium sp.

G. graminis

G. saubinetii

P. cyclopium

P. glaucum

$R$. oryzae

B. cinerea

M. laxa

M. piriformis

P. expansum

P. glaucum

R. stolonifer
$1490 \quad 10 \times 10^{-3} \quad$ lethal

$67 \quad 45 \times 10^{-5} \quad 50 \%$ growth inhibition $6 \mathrm{~d}$

$19413 \times 10^{-4} \quad 100 \%$ growth inhibition $6 \mathrm{~d}$

\section{Phenylethyl ITC}

\begin{tabular}{|c|c|c|}
\hline 4 & $25 \times 10^{-6}$ & minimum for inhibition \\
\hline 20 & $12 \times 10^{-5}$ & $100 \%$ growth inhibition \\
\hline 1 & $61 \times 10^{-7}$ & no zoospore formation \\
\hline 2.6 & $16 \times 10^{-6}$ & $50 \%$ growth inhibition $4 d$ \\
\hline 3.5 & $21 \times 10^{-6}$ & $100 \%$ growth inhibition $4 \mathrm{~d}$ \\
\hline 12 & $75 \times 10^{-6}$ & $100 \%$ growth inhibition $>14 d$ \\
\hline 3 & $18 \times 10^{-6}$ & $100 \%$ growth inhibition \\
\hline 5 & $31 \times 10^{-6}$ & $100 \%$ growth inhibition \\
\hline 20 & $12 \times 10^{-5}$ & $100 \%$ growth inhibition \\
\hline 0.2 & $10 \times 10^{-7}$ & minimum for inhibition in hs \\
\hline 2 & $12 \times 10^{-6}$ & $100 \%$ growth inhibition \\
\hline 8 & $48 \times 10^{-6}$ & $50 \%$ growth inhibition $6 \mathrm{~d}$ \\
\hline 12 & $76 \times 10^{-6}$ & $100 \%$ growth inhibition $6 \mathrm{~d}$ \\
\hline 5 & $31 \times 10^{-6}$ & minimum for inhibition \\
\hline 22 & $>75 \times 10^{-5}$ & $50 \%$ growth inhibition $6 \mathrm{~d}$ \\
\hline
\end{tabular}

\section{4-Hydroxybenzyl ITC}

$\begin{array}{rll}450 & 27 \times 10^{-4} & \text { minimum for inhibition of germ. } \\ 90 & 55 \times 10^{-5} & \text { minimum for inhibition of germ. } \\ 220 & 13 \times 10^{-4} & \text { minimum for inhibition of germ. } \\ 90 & 55 \times 10^{-5} & \text { minimum for inhibition of germ. } \\ 2000 & 12 \times 10^{-3} & \text { minimum for inhibition } \\ 1800 & 11 \times 10^{-3} & \text { minimum for inhibition of germ. }\end{array}$




\begin{tabular}{|c|c|}
\hline${ }^{\mathrm{a}}$ Bacteria: & Fungi: \\
\hline Bacillus subtilis & Aphanomyces eutiches \\
\hline Bacillus cereus & Aspergillus alliaceus \\
\hline Escherichia coli & Aspergillus niger \\
\hline Propionibacterium petersonii & Botrytis allii \\
\hline Propionibacterium shermanii & Botrytis cinerea \\
\hline Proteus vulgaris & Colletotrichum circinans \\
\hline Pseudomonas fragi & Cytospora \\
\hline Pseudomonas aeruginosa & Fusarium \\
\hline Salmonella enteritidis & Fusarium oxysporum \\
\hline Sarcina lutealis & Fusarium solani \\
\hline \multirow[t]{12}{*}{ Staphylococcus aureus } & Gaeumannomyces graminis \\
\hline & Gibberella saubinetii \\
\hline & Monila sitophila \\
\hline & Monilinia laxa \\
\hline & Mucor piriformis \\
\hline & Penicillium chrysogenum \\
\hline & Penicillium cyclopium \\
\hline & Penicillium expansum \\
\hline & Penicillium glaucum \\
\hline & Phytophthora palmivora \\
\hline & Rhizopus oryzae \\
\hline & Rhizopus stolonifer \\
\hline${ }^{b}$ headspace concentration & \\
\hline
\end{tabular}

Fungi: 
References: Angus et al. 1994; lori et al. 1993; Isshiki et al. 1992; Kanemaru and Miyamoto 1990; Fenwick et al. 1983; Tang and Takenaka 1983; Rutkowski et al. 1972; Lewis and Papavizas 1971;

Drobnica et al. 1967a; Virtanen 1965; Davis 1964; McKay et al. 1959; Hooker et al. 1943; Walker, et al. 1937. 
Table 4. EPA Registrations for Various Isothiocyanates

EPA Registration Number

499-136

499-137

499-138

$731-15$

$731-22$

2139-55

2139-76

3008-77

$5332-7$

$5332-8$

61966-4

$61966-5$

61966-7

67064-3

70160-1

$70160-2$

70160-3

70160-4
Type

repellent-vertebrates repellent-vertebrates repellent-vertebrates repellent-vertebrates repellent-vertebrates

Fungicide, insecticide, miticide

Fungicide, insecticide, miticide, nematicide, herbicide fungicide

repellent vertebrates, herbicide repellent, herbicide

insecticide, miticide, repellent

insecticide, miticide, repellent repellent-vertebrates repellent-vertebrates insecticide, miticide, repellent repellent-vertebrates repellent-vertebrates insecticide, miticide, repellent
Isothiocyanate

propenyl
propenyl
propenyl
propenyl
propenyl
methyl
methyl
methyl
propenyl
propenyl
propenyl
propenyl
propenyl
propenyl
propenyl
propenyl
propenyl
propenyl




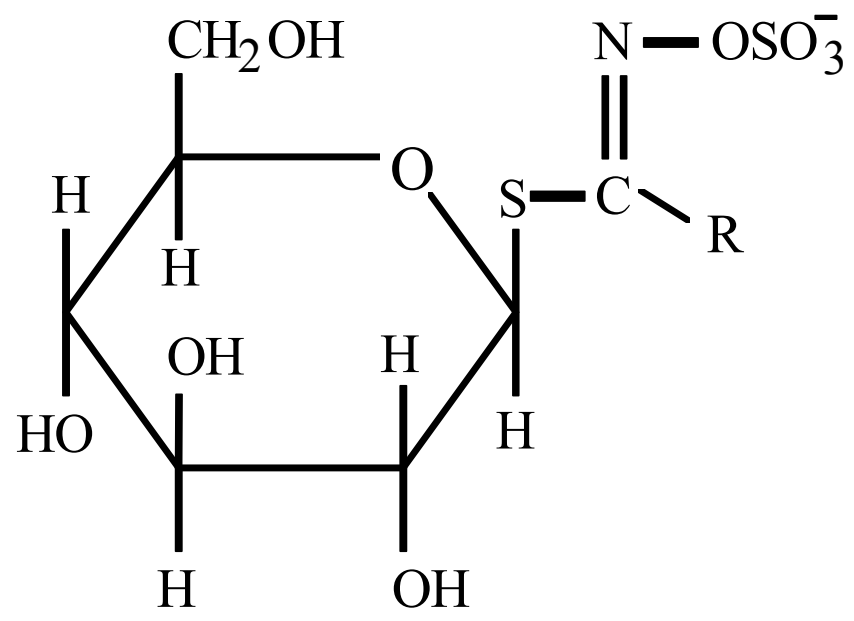

Figure 1. Generalized structure of glucosinolates 


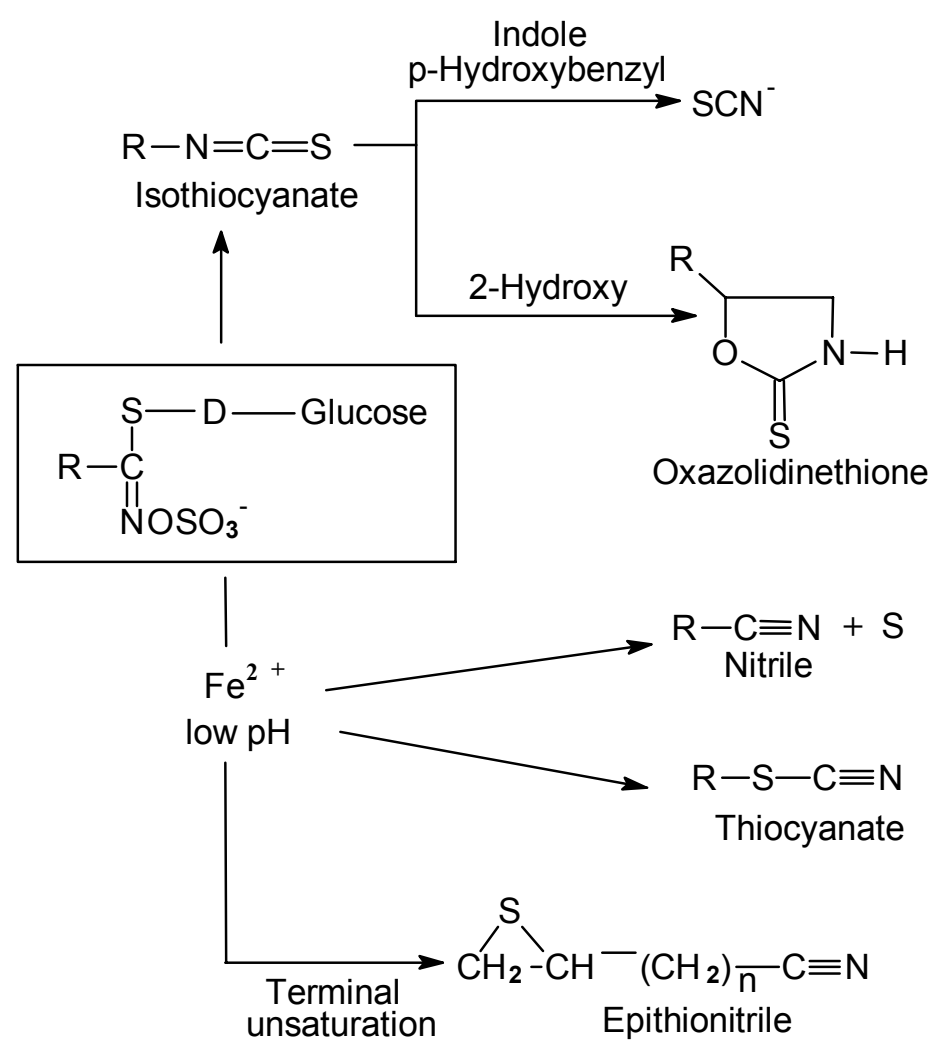

Figure 2. Glucosinolate degradation pathway ${ }^{1}$

\footnotetext{
${ }^{1}$ Enzymatic hydrolysis results in production of glucose followed by $\mathrm{HSO}_{4}{ }^{-}$. At least seven other products have been observed. Oxazolidinethione and $\mathrm{SCN}^{-}$are thought to be formed from unstable $\mathrm{R}-\mathrm{N}=\mathrm{C}=\mathrm{S}$ intermediates.
} 


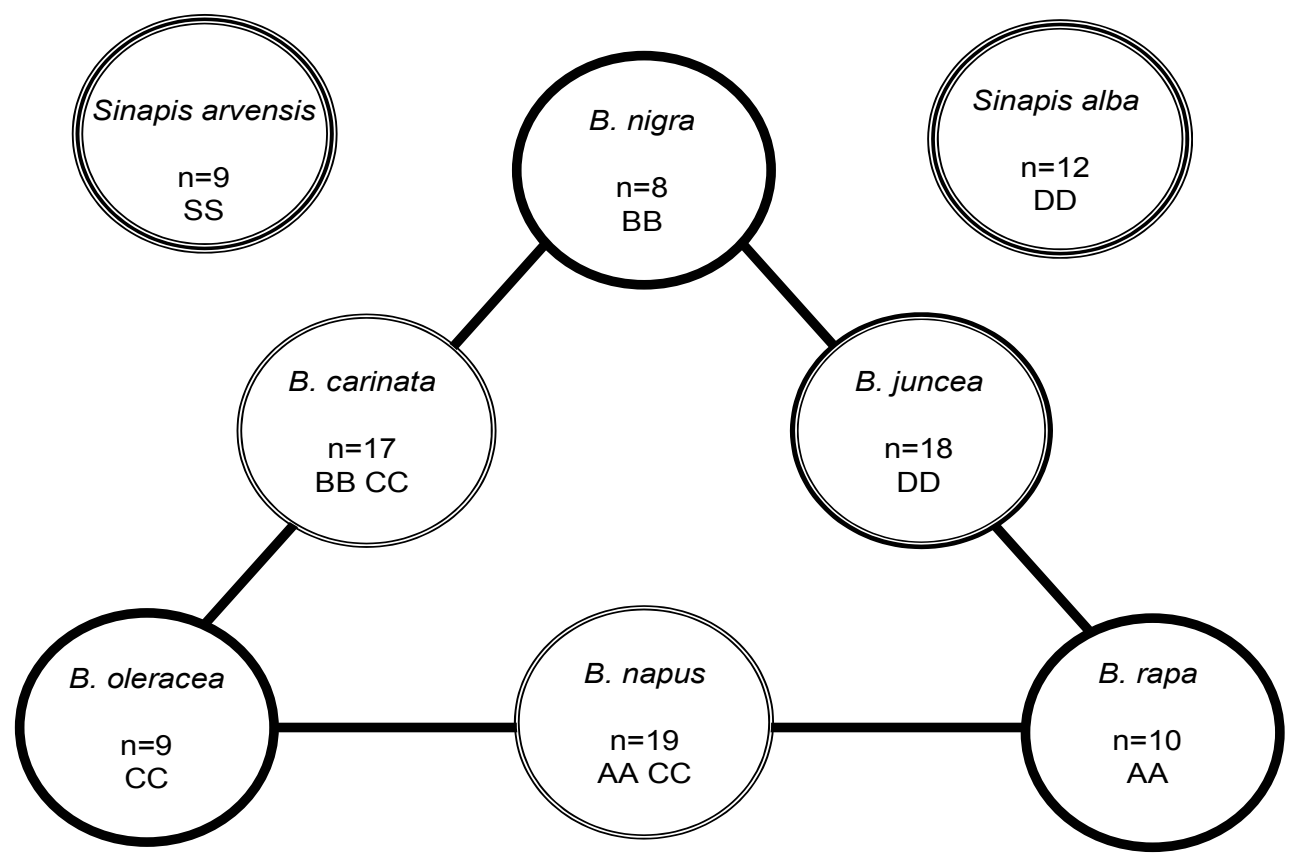

Figure 3. Relationship between Brassica species as described by U (1935) 


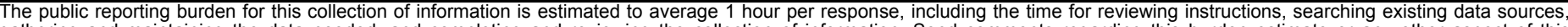

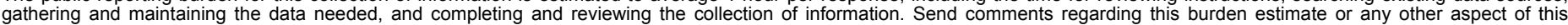

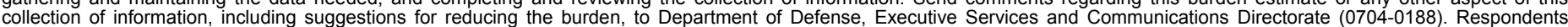

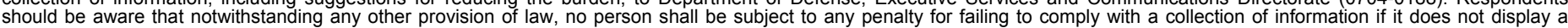

should be aware that notwithstanding

PLEASE DO NOT RETURN YOUR FORM TO THE ABOVE ORGANIZATION. July 2005

Subcontract Report

4. TITLE AND SUBTITLE

Glucosinolate-Containing Seed Meal as a Soil Amendment to

Control Plant Pests: 2000-2002

5a. CONTRACT NUMBER

DE-AC36-99-G010337

5b. GRANT NUMBER

5c. PROGRAM ELEMENT NUMBER

6. AUTHOR(S)

K. Shaine Tyson, J. Brown, M. J. Morra

5d. PROJECT NUMBER

NREL/SR-510-35254

5e. TASK NUMBER

FC059400

5f. WORK UNIT NUMBER
7. PERFORMING ORGANIZATION NAME(S) AND ADDRESS(ES)

University of Idaho

Moscow, Idaho
8. PERFORMING ORGANIZATION REPORT NUMBER

XC0-9-29095-01

9. SPONSORING/MONITORING AGENCY NAME(S) AND ADDRESS(ES)

National Renewable Energy Laboratory

1617 Cole Blvd.

Golden, CO 80401-3393

10. SPONSOR/MONITOR'S ACRONYM(S) NREL

11. SPONSORING/MONITORING AGENCY REPORT NUMBER NREL/SR-510-35254

12. DISTRIBUTION AVAILABILITY STATEMENT

National Technical Information Service

U.S. Department of Commerce

5285 Port Royal Road

Springfield, VA 22161

13. SUPPLEMENTARY NOTES

NREL Technical Monitor: K. Shaine Tyson

14. ABSTRACT (Maximum 200 Words)

Plants may produce compounds that directly or indirectly affect their biological environment. These compounds fall within a broad category of compounds called allelochemicals, and are exclusive of food that influences growth, health, or behavior of other organisms (Whittaker and Feeney 1971). One reason for interest in allelochemicals is their potential for use in alternative pest management systems. Using plant-produced allelochemicals in agricultural and horticultural practices could minimize synthetic pesticide use, reduce the associated potential for environmental contamination, and contribute to a more sustainable agricultural system.

15. SUBJECT TERMS

glucosinolate; allelochemicals; pest management; pesticide

\begin{tabular}{l}
\hline 16. SECURITY CLASSIFICATION OF: \\
\begin{tabular}{|l|l|l|}
\hline $\begin{array}{c}\text { a. REPORT } \\
\text { Unclassified }\end{array}$ & $\begin{array}{c}\text { b. ABSTRACT } \\
\text { Unclassified }\end{array}$ & $\begin{array}{l}\text { c. THIS PAGE } \\
\text { Unclassified }\end{array}$ \\
\hline
\end{tabular} \\
\hline
\end{tabular}

\begin{tabular}{|c|c|}
\hline $\begin{array}{l}\text { 17. LIMITATION } \\
\text { OF ABSTRACT }\end{array}$ & $\begin{array}{l}\text { 18. NUMBER } \\
\text { OF PAGES }\end{array}$ \\
\hline UL & \\
\hline
\end{tabular}

19a. NAME OF RESPONSIBLE PERSON

19b. TELEPHONE NUMBER (Include area code) 